\title{
Organic Carbon in Hanford Single-Shell Tank Waste
}

\author{
J. J. Toth \\ C. E. Willingham \\ P. G. Heasler \\ P. D. Whitney
}

Completed: July 1994

Published: February 1995

Prepared for

Westinghouse Hanford Company

Waste Tank Safety Program

and the U.S. Department of Energy

under Contract DE-AC06-76RLO 1830

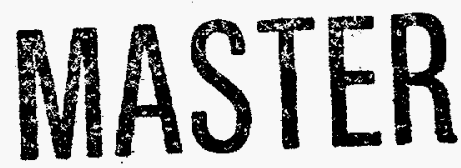

Pacific Northwest Laboratory

Richland, Washington 99352 


\section{DISCLAIMER}

This report was prepared as an account of work sponsored by an agency of the United States Government. Neither the United States Government nor any agency thereof, nor any of their employees, make any warranty, express or implied, or assumes any legal liability or responsibility for the accuracy, completeness, or usefulness of any information, apparatus, product, or process disclosed, or represents that its use would not infringe privately owned rights. Reference herein to any specific commercial product, process, or service by trade name, trademark, manufacturer, or otherwise does not necessarily constitute or imply its endorsement, recommendation, or favoring by the United States Government or any agency thereof. The views and opinions of authors expressed herein do not necessarily state or reflect those of the United States Government or any agency thereof. 


\section{DISCLAIMER}

Portions of this document may be illegible in electronic image products. Images are produced from the best available original document. 


\section{Executive Summary}

This report documents an analysis performed by Pacific Northwest Laboratory (PNL) involving the organic carbon laboratory measurement data for Hanford single-shell tanks (SSTs) obtained from a review of the laboratory analytical data. This activity was undertaken at the request of Westinghouse Hanford Company (WHC). The objective of this study is to provide a best estimate, including confidence levels, of total organic carbon (TOC) in each of the 149 SSTs at Hanford. The TOC analyte information presented in this report is useful as part of the criteria to identify SSTs for additional measurements or monitoring for the organic safety program. This report is a precursor to an investigation of TOC and moisture in Hanford SSTs, in order to provide best estimates for each together in one report.

Measured laboratory data were obtained for 75 of the 149 SSTs. The data represent a thorough investigation of data from 224 tank characterization datasets, including core-sampling and process laboratory data. Liquid and solid phase TOC values were investigated by examining selected tanks with both reported TOC values in solid and liquid phases. Some relationships were noted, but there was no clustering of data or significance between the solid and liquid phases.

A methodology was developed for estimating the distribution and levels of TOC in SSTs using a logarithmic scale and an analysis of variance (ANOVA) technique. The methodology grouped tanks according to waste type using the Sort On Radioactive Waste Type (SORWT) grouping method. The SORWT model categorizes Hanford SSTs into groups of tanks expected to exhibit similar characteristics based on major waste types and processing histories. The methodology makes use of laboratory data for the particular tank and information about the SORWT group of which the tank is a member. If the tank has no TOC laboratory data, known information about the SORWT group is used to infer the TOC value in that tank. Recommendations for a simpler tank grouping strategy based on organic transfer records were made.

Of the 149 SSTs, 59 had no TOC observations but did belong to a SORWT group with at least one TOC observation, and 15 tanks had no TOC observations where the SORWT group had no TOC data. A significant number (28) of the 75 tanks had only one TOC measurement. The laboratory data were used to obtain best-estimates of TOC at $95 \%$ confidence levels for all SSTs. Best-estimate TOC concentrations for each of the 149 SSTs are represented by the wet (as-is) median values, as shown in Table 4.10. The top ten tanks for the wet median basis are U-106, SX-103, U-105, U-107, U-108, U-109, U-102, S-101, S-103, and S-105. Two of these (U-106 and U-107) are on the original organic watchlist. The laboratory data, which present the TOC estimates on a wet basis, are converted to a dry basis to be consistent with the TOC criteria used in the organic safety program (Babad and Turner 1993). For comparison to TOC criteria of $5 \%$, the dry mean TOC values are recommended (Table 4.13). The top ten tanks for the dry mean basis are C-103, T-104, U-106, SX-106, U-203, U-204, 
T-102, U-105, U-201, and U-202. Three of these tanks (C-103, U-106, and SX-106) are on the original organic watchlist. It should be noted that recent laboratory measurements and studies indicate that previous measured high TOC values for T-104 are suspect because of measurement problems.

The organic constituents of the Track Radioactive Components Code (TRAC) waste inventories were also used to estimate organic concentrations in each of the SSTs. Inventories of six species were taken as TOC contributors: oxalate, citrate, acetate, EDTA, HEDTA, and ferrocyanide. TRAC organic waste concentrations were compared to the laboratory data when they were available, but no correlation between the TRAC estimate and laboratory measurements was found. 


\section{Contents}

Executive Summary $\ldots \ldots \ldots \ldots \ldots \ldots \ldots \ldots \ldots \ldots \ldots \ldots \ldots \ldots$ iii

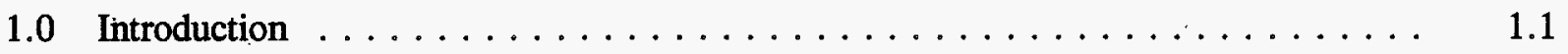

2.0 Background $\ldots \ldots \ldots \ldots \ldots \ldots \ldots \ldots \ldots \ldots \ldots \ldots \ldots \ldots \ldots \ldots \ldots$

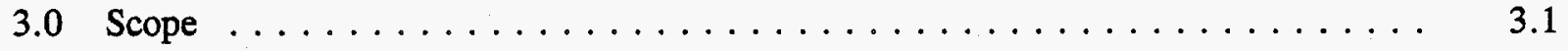

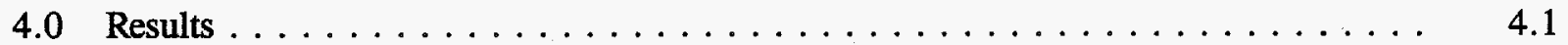

4.1 TRAC Inventory System Applied to TOC Laboratory Data . . . . . . . . . . 4.2

4.2 Methodology of Statistical Evaluation $\ldots \ldots \ldots \ldots \ldots \ldots \ldots$

4.3 Relationship of TOC to Other Variables in the Dataset . . . . . . . . . 4.11

4.4 Distributional Assumptions $\ldots \ldots \ldots \ldots \ldots \ldots \ldots \ldots \ldots \ldots \ldots$

4.5 Factors Included in the ANOVA Analysis $\ldots \ldots \ldots \ldots \ldots \ldots \ldots \ldots$

4.6 Conversion of TOC to Dry Basis $\ldots \ldots \ldots \ldots \ldots \ldots \ldots \ldots$

4.7 Results of Fits to TOC Data $\ldots \ldots \ldots \ldots \ldots \ldots \ldots \ldots \ldots \ldots$

4.8 TOC Criteria for Watch List Tanks $\ldots \ldots \ldots \ldots \ldots \ldots \ldots \ldots . \ldots \ldots$

5.0 Conclusions and Recommendations $\ldots \ldots \ldots \ldots \ldots \ldots \ldots \ldots \ldots \ldots \ldots$

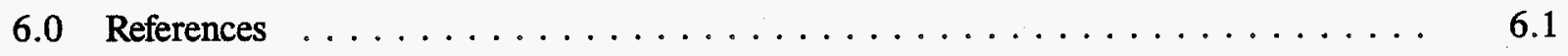

Appendix A - Laboratory Techniques $\ldots \ldots \ldots \ldots \ldots \ldots \ldots \ldots \ldots \ldots \ldots \ldots \ldots$

Appendix B - Laboratory Data $\ldots \ldots \ldots \ldots \ldots \ldots \ldots \ldots \ldots \ldots \ldots \ldots \ldots \ldots$

Appendix C - Description of Sort on Radioactive Waste Type Group . . . . . . . . . C.1

Appendix D - Laboratory Report Source Information . . . . . . . . . . . . . D.1 


\section{Figures}

4.1 TRAC Versus Laboratory Measurement Data (Wet) for Selected SSTs,

Liquid Phase . . . . . . . . . . . . . . . . . . . 4.2

4.2 TRAC Versus Laboratory Measurement Data (Wet) for Selected SSTs,

Solid Phase

4.3 Laboratory TOC Measurements (Wet) Versus Waste Type, Liquid or

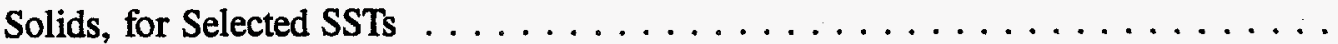

4.4 Percent TOC Measurements (Wet) Plotted Against the Year of the

Document in Which the Measurement was Reported

4.5 Q-Q Plot of Untransformed Laboratory TOC Measurements

4.6 Q-Q Plot of the Logarithm of the Laboratory TOC Measurements . . . . . . . 4.15

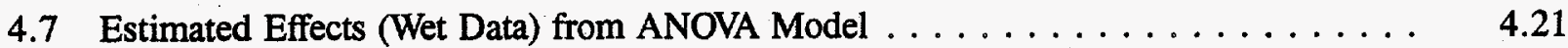

4.8 Estimated Effects (Wet Data) from ANOVA Model (continued) $\ldots \ldots \ldots \ldots \ldots$. . . 4.22

4.9 Estimated Effects (Wet Data) from ANOVA Model (continued) $\ldots \ldots \ldots \ldots \ldots \ldots$

4.10 Probability of $5 \%$ Exceedance for 149 SSTs, Wet Median Basis $\ldots \ldots \ldots \ldots . \ldots 45$

4.11 Probability of $5 \%$ Exceedance for 149 SSTs, Wet Mean Basis . . . . . . . . . 4.45

4.12 Probability of $5 \%$ Exceedance for 149 SSTs, Dry Median Basis $\ldots \ldots \ldots . \ldots 46$

4.13 Probability of $5 \%$ Exceedance for 149 SSTs, Dry Mean Basis . . . . . . . . . 4.46 


\section{Tables}

4.1 Distribution of TOC Measurements Across Tanks $\ldots \ldots \ldots \ldots \ldots . \ldots \ldots$

4.2 Laboratory Values (Wet) Versus TRAC Estimates for Supernatent for Selected SSTs $\ldots \ldots \ldots \ldots \ldots \ldots \ldots \ldots \ldots \ldots \ldots \ldots \ldots \ldots \ldots$

4.3 Laboratory Data for Solids Versus TRAC Estimates for

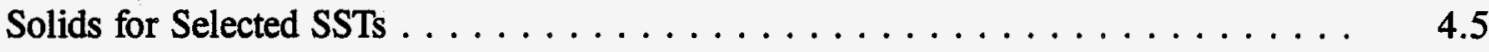

4.4 TOC Measurement Counts, Raw Data $\ldots \ldots \ldots \ldots \ldots \ldots \ldots \ldots \ldots \ldots$

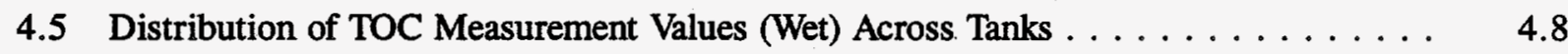

4.6 Estimate of Percent TOC (Dry) for 149 Single-Shell Tanks According to the TRAC Dataset, in Descending Order of TOC . . . . . . . 4.9

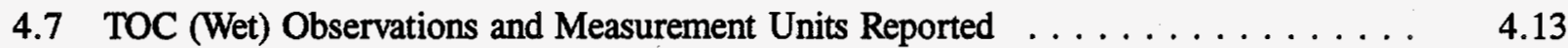

4.8 Estimates of ANOVA Model Parameters (logged) for the Laboratory Dataset . . . . . . . . . . . . . . . . . . . . . . . . 4.20

4.9 Best Estimates for Each SORWT Group $\ldots \ldots \ldots \ldots \ldots \ldots \ldots \ldots$

4.10 TOC Wet Units, Median Estimate $\ldots \ldots \ldots \ldots \ldots \ldots \ldots \ldots \ldots \ldots$

4.11 TOC Wet Units, Mean Estimate $\ldots \ldots \ldots \ldots \ldots \ldots \ldots \ldots \ldots \ldots \ldots$

4.12 TOC Dry Units, Median Estimate $\ldots \ldots \ldots \ldots \ldots \ldots \ldots \ldots \ldots$

4.13 TOC Dry Units, Mean Estimate . . . . . . . . . . . . . . . . 4.39 


\subsection{Introduction}

Safety of Hanford single-shell tanks (SSTs) containing organic carbon is a concern because the carbon in the presence of oxidizers $\left(\mathrm{NO}_{3}\right.$ or $\left.\mathrm{NO}_{2}\right)$ is combustible when sufficiently concentrated and exposed to elevated temperatures. A propagating chemical reaction could potentially occur at high temperature (above $200^{\circ} \mathrm{C}$ ). The rapid increase in temperature and pressure within a tank might result in the release of radioactive waste constituents to the environment (Fisher 1990).

WHC has placed nine tanks on the watchlist that collectively represents a Hanford Site high-level waste storage tank "safety issue." Eight of the tanks are included on the watchlist based on inferred TOC content $>3 \mathrm{wt} \%$ (dry basis) from limited data. Some of the tanks are on the watchlist because TRAC data indicate organic levels above $3 \%$; others are on the list based on liquid sample TOC measurement results. A ninth tank (C-103) is included because it has a floating organic layer (Babad and Turner 1993). The basis for the 3 wt\% threshold is based on laboratory tests involving mixtures of sodium acetate, sodium nitrate, and inert diluents (Fisher 1990). The nine tanks on the organic tanks watchlist are: B-103, C-103, S-102, SX-106, TX-105, TX-118, U-106, U-107, and U-111. Approximately 11,000 metric tons ( 5 million pounds) of organic agents (principally complexing agents) are known to have been disposed as waste to the SST system.

The purpose of this study is to gather available laboratory information about the organic carbon waste inventories stored in the Hanford SSTs. Specifically, the major objectives of this investigation are:

- Review laboratory analytical data and measurements for SST composite core and supernatant samples for available organic data.

- Assess the correlation of organic carbon estimated utilizing the TRAC computer code compared to laboratory measurements.

- From the laboratory analytical data, estimate the TOC content with confidence levels for each of the 149 SSTs.

The laboratory information gathered in this report is used to assess the TOC for each of the SSTs. These estimates are to be used in a value of information (VOI) computerized risk assessment model being developed for a Data Requirement Study (DRS) assessment for organics. Therefore, the study must produce estimates for TOC and also some measure of uncertainty (standard deviations, confidence bounds) so the distribution functions can be constructed. Results from the VOI risk assessment model will be used to determine the best mitigation strategy for a tank, and to determine which tanks might be of highest risk concern. But most importantly, the model can be used to determine the value of obtaining better information about tank TOC. Use of the model will determine whether or not it is worthwhile to sample TOC more precisely. 
TOC has been estimated at Hanford by using transfer records. From these records, one can determine what waste streams were directed into a specific tank, and it is conceptually an easy matter to use this information to obtain a TOC estimate. A computer program (TRAC) makes estimates using this strategy. However, the estimates can differ by orders of magnitude from measured results because the transfer records are incomplete and the transfer history of some tanks is very complex. One of the objectives of this study is to assess TRAC estimates of TOC.

For this study, we produced estimates using tank sampling data. The data consist of a set of compiled recorded measurements taken during the past 15 years. This dataset consists of 223 measurements that were made on core and supernatant samples analyzed in both Hanford 222-S and 325 analytical laboratories. These measurements were assembled from various reports and are tabulated in Appendix B of this report.

The measurements express concentration in terms of wet weight. To make the reported TOC values consistent with the risk calculations, a correction factor must be applied to the wet TOC values to reduce them to dry weight. In this study, we first calculate estimates on a wet-weight basis and then convert the estimates to dry weight. All of the results in this report, except where noted, are expressed in wet-weight units.

At present, about half the SSTs are represented in the database, so direct estimates of TOC can only be calculated for only half the tanks. To produce estimates for the unsampled tanks, a statistical model is constructed to relate to unsampled tanks. A random-effects ANOVA model was used to estimate TOC for unsampled tanks.

Since this dataset did not result from a designed experiment, the measurements may contain substantial bias. At least two potential sources of bias could be eliminated if more information was gathered. If the sample location (riser, depth) for each sample could be supplied, location biases could be better defined, and if measurement method could be supplied, biases associated with the laboratory procedure could be eliminated. The best-estimate TOC concentrations are based on the median estimates. The selection of the median instead of the mean is based on the assumption that the predominant contribution to within-tank variation is measurement error, and not spatial distribution. These issues are discussed in Section 4 of this report.

In this report, following the background and scope discussions, the analyses results are described in terms of laboratory data, TRAC results, ANOVA statistical model, and TOC estimates for all 149 SSTs using wet (median and mean) and dry (median and mean) basis. Probabilities of exceeding the $5 \%$ threshold value are also given. The 5\% threshold value is described in Babad and Turner (1993). This material is described in Sections 4.1 through 4.8 . 


\subsection{Background}

The Tank Waste Remediation System (TWRS) Program at Hanford is using the Data Requirements Study (DRS) concept specifically to build a database of characterization data with an understanding of its confidence level, using process knowledge and characterization data. Two methods of assessing the organic carbon levels are investigated in this report: 1) the analysis of Variance (ANOVA) technique and 2) TRAC inventories. The ANOVA technique groups tanks of similar waste type according to the Sort on Radioactive Waste Type (SORWT) method.

The ANOVA technique utilizes laboratory data reporting TOC measurements as the sample exists in the tank (i.e., wet basis, or with moisture present). However, the criteria for organic watchlist tanks are on a dry basis (Babad and Turner 1993). Therefore, the ANOVA results are converted from a wet to dry basis to be consistent with the organic safety watchlist criteria (see Section 4.6).

Westinghouse Hanford Company reviewed much of the historical TOC laboratory data and conducted preliminary organic carbon assessments based on the TRAC inventory. Klem (1990) estimated values of TOC for 47 SSTs, averaging laboratory values when multiple data were available.

Schulz (1980) reported on results of the organic complexant concentrations (wet basis) for the purpose of understanding the effect of strontium removal in an ion exchange process. The Schulz results indicated high levels of TOC, up to $10 \%$ TOC for tank number U-106. Crippen, in his 1991 letter (see page 4.2 for title), summarized historical data for 49 SSTs based on TRAC inventories, on a dry basis. Crippen's results indicated TOC levels up to $4.93 \%$ for tank number SX-106.

Fisher (1990) presented assessments for TOC of selected tanks based on laboratory values and TRAC inventory estimates. Fisher identifies seven tanks that may contain explosive mixtures of organic salts from the laboratory data and TRAC estimates, based on Schulz (1980). The laboratory values are based on Schulz (1980), and the TRAC data are based on Jungfleisch (1984).

During the 1970s and 1980s there were many characterization studies made of the Hanford radioactive waste and reports written documenting laboratory measurements of core and supernatant samples. The level of detail in the documents depended upon the requirements for the measurement, the number of cores or samples taken, and amount of core recovery. During the 1990s statistical evaluation of the core samples was initiated to estimate spacial variability within the tanks. Species or component-level data for the organic constituents were usually not measured or reported.

The TRAC waste characterization, developed in 1983, was based on process knowledge and tank transfer records. The TRAC system was developed primarily for radionuclides, but chemical inventories for 30 species are included. The only organic species inventoried in the TRAC dataset are hydroxyacetate, oxalate, citrate, ethylenediaminetetraacetic acid (ETDA), and hydroxyethylenediaminetriacetic acid (HEDTA). The ferrocyanide inventory is also included in the TRAC database. TRAC inventory assessments are made on a dry basis. The TRAC database has not been validated for process chemicals. Estimates of process chemical inventories were input to the TRAC database, but 
there were no validation studies with laboratory analysis. In this report, the TOC laboratory measurements are compared with TOC inventories calculated in the TRAC dataset to assess or validate TRAC inventories with actual measurements.

The SORWT grouping technique was developed as a methodology to group tanks of similar radioactive waste types (Hill et al. 1991). In the SORWT methodology, tanks are fit into families or groups according to the types of wastes admitted to the tanks. The resulting groups can be used to compare tank properties within the same group. In this report, the organic carbon levels determined from laboratory measurements of tanks are grouped according to the SORWT families. Determination of the organic carbon levels for all SSTs is based on available laboratory data and SORWT grouping. 


\subsection{Scope}

This report provides estimates of the organic carbon concentrations for the SST wastes by using statistical evaluations applied to chemical analysis information gathered from tank reports. The laboratory data are collected from historical tank characterization information and process laboratory reports. The laboratory measurements collected are used to estimate the median total organic carbon level in the tank, and variation between and within tanks. Organic carbon levels of selected tanks without laboratory measurements are estimated. These estimates are provided by comparing tanks of similar waste types (SORWT groups).

This report also assesses the quality of organic constituent information in the TRAC inventory database as it compares to measured total organic carbon concentrations in the SSTs. Historical information about tank transfers is not directly included as a source of information in the determination of TOC for this report. However, the SORWT grouping model does contain information pertaining to waste types, volumes, and tank transfers (Hill 1991).

The laboratory data used in this report were obtained from two types of reports: characterization reports and process laboratory documents. Characterization reports involved full laboratory analysis of core samples and included multiple sample analysis. Laboratory procedures and standards were often documented in the core report characterization studies. The core characterization reports were prepared to provide detailed characterization of the tank in question.

Process laboratory analysis reports were the second important source of analytical information used for total organic carbon. Process laboratory reports were prepared on many supernatant samples for the purpose of gathering chemical information to identify certain characteristics of the tank. The process laboratory reports often analyze for a few constituents that were important characteristics at the time of the analysis, not a full detailed characterization of the tank. When organic carbon analysis was reported, the TOC values were included in the laboratory measurement database. 


\subsection{Results}

In Section 4.1, the TRAC inventory dataset is examined to identify possible correlations to the laboratory data. TRAC TOC values for both supernatants and sludges are compared to laboratory data.

In order to establish a basis for determining a best estimate of TOC for all tanks, a statistical model is employed. To estimate the concentration of TOC for all the SSTs where laboratory measurements are available for a limited number of the tanks, it is necessary to have a basis for establishing the distribution of TOC in all the tanks, and a basis for selecting the best estimate of TOC for all tanks. Laboratory results are collected into a single dataset and analyzed using an Analysis of Variance (ANOVA) statistical technique. The ANOVA method applies distributional assumptions to the entire dataset to assess averages and standard deviations. To characterize the TOC tanks with similar waste types, the SORWT grouping technique was used in the ANOVA methodology. Conversion of the ANOVA TOC results from a wet basis to a dry basis is required to be consistent with the organic safety watchlist criteria.

Before evaluating the TRAC and ANOVA results, a brief overview of the data, shown in Appendix B, would be useful so that the reader can develop a feeling for the "raw data." The ANOVA model results presented in the following sections also produce an accurate description of the raw data but the reader may feel less comfortable using them in this manner. Table 4.1 below gives a brief summary of the distribution of TOC measurements across SSTs.

There is a significant number of SSTs with only one TOC measurement, 28 out of 75 tanks, and 74 tanks without a TOC measurement of any kind.

Table 4.1. Distribution of TOC Measurements Across Tanks

\begin{tabular}{||l|c||}
\hline Number of tanks without TOC measurements & 74 \\
\hline Total number of tanks with TOC measurements & 75 \\
\hline \hline Number of tanks with 1 TOC measurements & 28 \\
\hline Number of tanks with 2 TOC measurements & 17 \\
\hline Number of tanks with 3 TOC measurements & 12 \\
\hline Number of tanks with 4 TOC measurements & 5 \\
\hline Number of tanks with 5 TOC measurements & 3 \\
\hline Number of tanks with more than 5 TOC measurements & 10 \\
\hline
\end{tabular}




\subsection{TRAC Inventory System Applied to TOC Laboratory Data}

The Hanford TRAC system estimates the inventory of stable chemical species and radionuclides from process knowledge, storage tank transfers, and radiological degradation effects (Jungfleisch 1984). The TRAC dataset inventory estimated for 1990 , first quarter, was used in the assessment of total organic carbon in each of the SSTs. The inventories of six species that were taken as contributors to TOC are oxalate, citrate, acetate, EDTA, HEDTA and ferrocyanide. The contributors to TOC include all carbon contained in energetic constituents. Although the carbon contribution from ferrocyanide is inorganic, it is included in the TOC TRAC assessment because of its contribution to fuel content in the tank.

A comparison of the TRAC assessments to laboratory-measured values indicates there is little correlation between the two (correlation of fit value is only $4 \%$, out of a possible $100 \%$ for liquids), as shown in Figures 4.1 and 4.2 for liquids and solids, respectively. A correlation would be evident by a linear pattern and none is apparent. The TOC laboratory data and TRAC data used in the figures are shown in Tables 4.2 and 4.3. TRAC dataset values are on a wet basis.

The TOC results generated in this report using the TRAC database agree with the TRAC-generated estimates provided by M. D. Crippen. ${ }^{(a)}$ The TOC estimates employing the TRAC dataset are summarized for each tank in Table 4.6 (page 4.9), in descending order of percent TOC. Crippen used the same organic constituents plus ferrocyanide to estimate the TOC values in the SSTs.

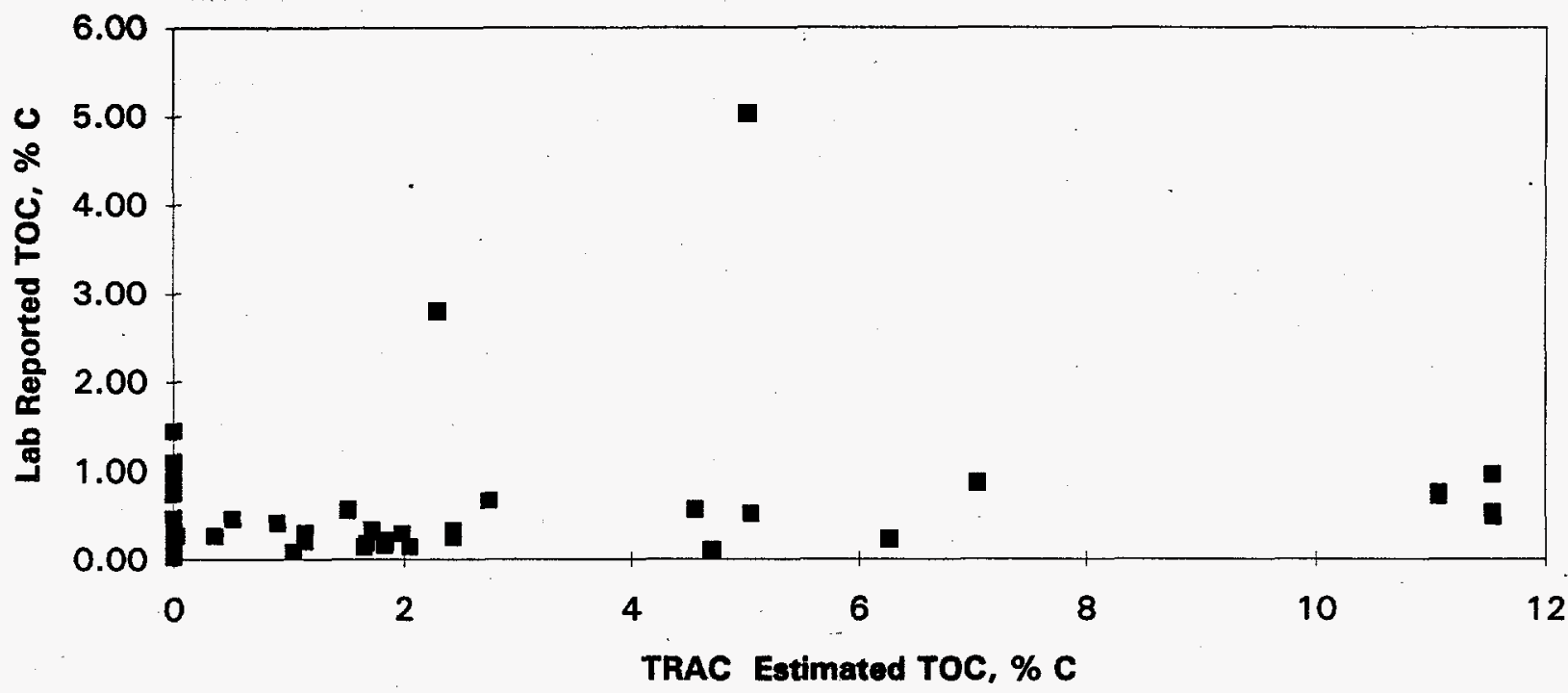

Figure 4.1. TRAC Versus Laboratory Measurement Data (Wet) for Selected SSTs, Liquid Phase

(a) Letter, Crippen, M. D. to P. Hill, "Historical Data for Organic Tanks," Westinghouse Hanford Company, November 20, 1991. 


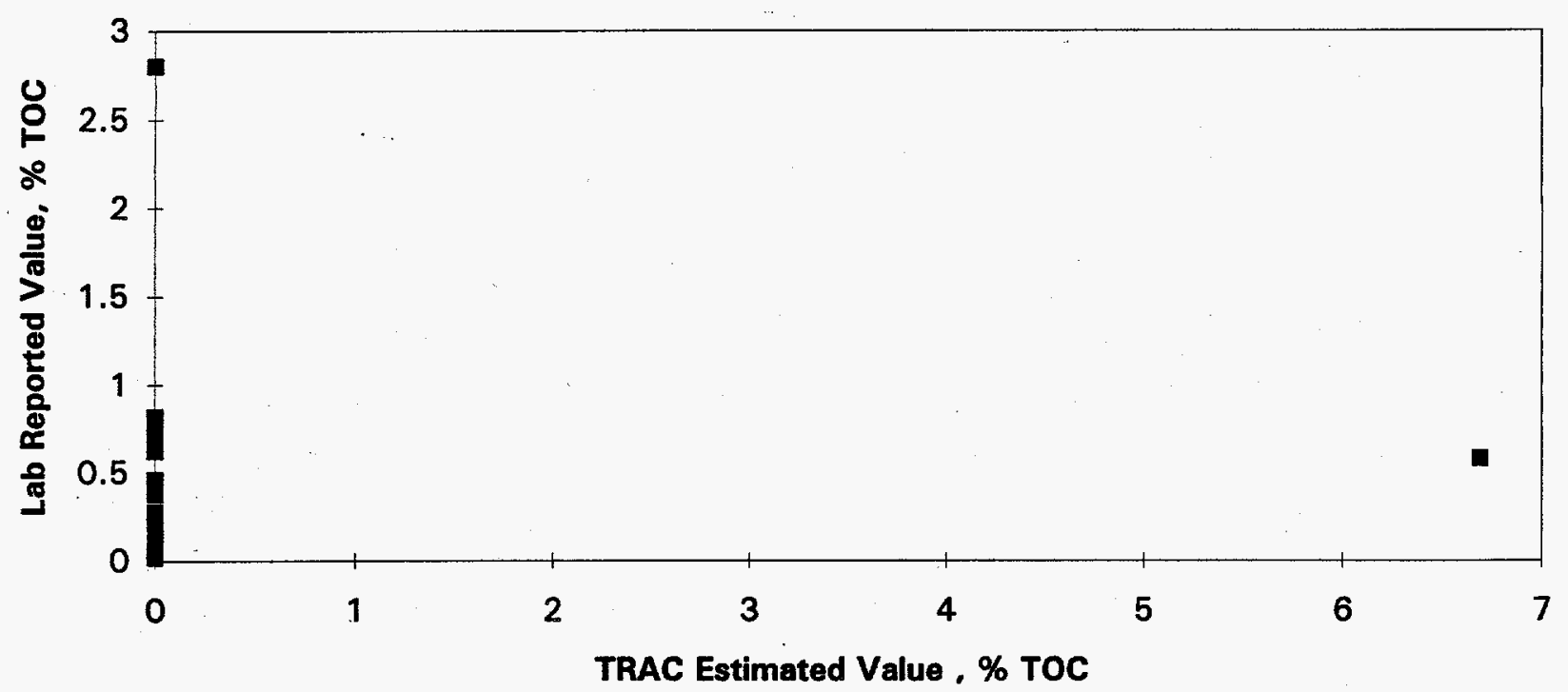

Figure 4.2. TRAC Versus Laboratory Measurement Data (Wet) for Selected SSTs, Solid Phase (Correlation of fit is $0.5 \%$ out of a possible $100 \%$ )

Table 4.2. Laboratory Values (Wet) Versus TRAC Estimates for Supernatant for Selected SSTs

\begin{tabular}{|c|c|c|c|c|c|}
\hline Tank & TRAC \% TOC & $\begin{array}{c}\text { Lab Reported } \\
\text { Percent }\end{array}$ & Tank & TRAC \% TOC & $\begin{array}{c}\text { Lab Reported } \\
\text { Percent }\end{array}$ \\
\hline A-101 & 0 & 0.40 & C-103 & 1.51 & 0.55 \\
\hline A-101 & 0 & 0.84 & C-104 & 0 & 0.87 \\
\hline A-102 & 11.54 & 0.49 & C-105 & 6.26 & 0.23 \\
\hline A-102 & 11.54 & 0.53 & C-106 & 0 & 0.19 \\
\hline A-102 & 11.54 & 0.96 & C-107 & 1.03 & 0.09 \\
\hline A-102 & 11.54 & 0.96 & C-110 & 0 & 0.05 \\
\hline A-103 & 4.56 & 0.57 & C-112 & 0 & 0.33 \\
\hline A-103 & 4.56 & 0.56 & S-111 & 0.89 & 0.42 \\
\hline A-106 & 0 & 0.42 & SX-101 & 0 & 0.24 \\
\hline AX-101 & 0 & 1.10 & SX-104 & 2.43 & 0.25 \\
\hline AX-101 & 0 & 0.90 & SX-104 & 2.43 & 0.33 \\
\hline AX-101 & 0 & 0.75 & SX-106 & 5.02 & 5.03 \\
\hline AX-102 & 0 & 0.91 & T-107 & 0 & 0.07 \\
\hline
\end{tabular}


Table 4.2. (contd)

\begin{tabular}{|c|c|c|c|c|c||}
\hline Tank & TRAC \% TOC & $\begin{array}{c}\text { Lab Reported } \\
\text { Percent }\end{array}$ & Tank & TRAC \% TOC & $\begin{array}{c}\text { Lab Reported } \\
\text { Percent }\end{array}$ \\
\hline AX-102 & 0 & 1.45 & T-112 & 0 & 0.19 \\
\hline AX-103 & 2.3 & 2.80 & TX-102 & 1.83 & 0.16 \\
\hline BX-104 & 0 & 0.48 & TX-103 & 0.35 & 0.27 \\
\hline BX-104 & 0 & 0.43 & TX-105 & 7.04 & 0.87 \\
\hline BX-105 & 11.07 & 0.71 & TX-106 & 0 & 0.43 \\
\hline BX-105 & 11.07 & 0.76 & TX-109 & 2.75 & 0.67 \\
\hline BY-102 & 1.65 & 0.15 & TX-110 & 1.98 & 0.30 \\
\hline BY-102 & 1.65 & 0.14 & TX-111 & 0.5 & 0.46 \\
\hline BY-103 & 1.67 & 0.19 & TX-112 & 0.02 & 0.27 \\
\hline BY-105 & 1.84 & 0.20 & TX-114 & 0 & 0.20 \\
\hline BY-105 & 1.84 & 0.22 & TX-115 & 0 & 0.03 \\
\hline BY-106 & 1.13 & 0.22 & TX-116 & 0 & 0.08 \\
\hline BY-106 & 1.13 & 0.21 & TX-118 & 4.7 & 0.10 \\
\hline BY-107 & 1.13 & 0.31 & TX-118 & 4.7 & 0.11 \\
\hline BY-109 & 1.72 & 0.32 & TY-103 & 2.05 & 0.15 \\
\hline BY-109 & 1.72 & 0.34 & TY-104 & 0 & 0.17 \\
\hline C-103 & 1.51 & 0.57 & TY-104 & 0 & 0.16 \\
\hline C-103 & 1.51 & 0.57 & TY-104 & 0 & 0.20 \\
\hline C-103 & 1.51 & 0.57 & U-111 & 5.05 & 0.52 \\
\hline
\end{tabular}


Table 4.3. Laboratory Data for Solids Versus TRAC Estimates for Solids for Selected SSTs

\begin{tabular}{||c|c|c||}
\hline Tank & Solid Wastes TRAC \% TOC & Lab Reported Percent TOC \\
\hline A-102 & 0 & 0.72 \\
\hline A-102 & 0 & 0.79 \\
\hline A-103 & 0 & 0.80 \\
\hline A-103 & 0 & 0.77 \\
\hline A-106 & 0 & 0.62 \\
\hline A-106 & 0 & 0.72 \\
\hline A-106 & 0 & 0.62 \\
\hline A-106 & 0 & 0.72 \\
\hline B-110 & 0 & 0.04 \\
\hline BX-104 & 0 & 0.18 \\
\hline BX-105 & 0 & 0.38 \\
\hline BX-105 & 0 & 0.18 \\
\hline C-103 & 0 & 0.39 \\
\hline C-103 & 0 & 0.26 \\
\hline C-104 & 0 & 0.44 \\
\hline C-105 & 0 & 0.10 \\
\hline C-106 & 0 & 0.08 \\
\hline C-106 & 0 & 0.46 \\
\hline C-112 & 0.69 & 0.58 \\
\hline SX-102 & 0 & 0.82 \\
\hline TY-101 & 0 & 0.07 \\
\hline TY-102 & 0 & 0.02 \\
\hline TY-103 & 0 & 0.15 \\
\hline TY-103 & 0.07 \\
\hline TY-104 & 0.28 \\
\hline TY-104 & 0 & 0.09 \\
\hline TY-104 & 0 & 0.1 \\
\hline
\end{tabular}


Table 4.3. (contd)

\begin{tabular}{||c|c|c||}
\hline Tank & Solid Wastes TRAC \% TOC & Lab Reported Percent TOC \\
\hline TY-104 & 0 & 0.20 \\
\hline TY-105 & 0 & 0.08 \\
\hline TY-106 & 0 & 0.09 \\
\hline TY-106 & 0 & 0.25 \\
\hline TY-106 & 0 & 0.21 \\
\hline U-110 & 0 & 0.05 \\
\hline U-110 & 0 & 0.04 \\
\hline U-110 & 0 & 0.06 \\
\hline U-110 & 0 & 0.07 \\
\hline U-110 & 0 & 0.05 \\
\hline U-110 & 0 & 0.04 \\
\hline U-110 & 0 & 0.11 \\
\hline U-110 & 0 & 0.11 \\
\hline U-105 & 0 & 2.80 \\
\hline
\end{tabular}

\subsection{Methodology of Statistical Evaluation}

The tank data for which laboratory measurements exist can be used in assessing the concentration of TOC for tanks where no data are available by comparing tanks containing similar wastes. All tanks are classified according to the SORWT model as a methodology of grouping the tanks into similar waste types (Hill and Simpson 1991).

Several variables, or factors, are present in the datasets that may help explain the distribution of TOC measurements. The strategy is to include these factors in ANOVA models, so that the best predictive model can be constructed. Important factors that may affect TOC measurements are:

- type of waste measured (salt cake, liquid, sludge)

- tank 'SORWT' classification (tank group)

- Specific tank 
- Riser (horizontal) location of measurement

- Vertical location of measurement

- Laboratory measurement technique, or laboratory performing the analysis.

These factors could be used to produce many different ANOVA models, some that are quite complex. To obtain a reasonable class of ANOVA models to fit to the data, we plotted the data and performed some preliminary ANOVA analyses. The incompleteness of some information (primarily the location of the sample within the tank) also limits the type of model that could be fit to the data.

Some general observations about the distribution of laboratory measurements by waste type of liquids and solids (sludge + saltcake) are illustrated by the data in Table 4.4. Liquid measurements of TOC represent about two-thirds of the dataset.

The number of tanks with TOC measurements above 3, 4, and $5 \%$ TOC (wet basis) is provided in Table 4.5.

To determine whether or not to include waste type (solid, liquid) in the ANOVA model, TOC laboratory measurements of the two waste types, made on the same tank, and at the same time, are compared in Figure 4.3. The results in the figure indicate little comparison between the type of waste measure (liquid or sludge) and the TOC obtained.

The TOC estimates employing the TRAC dataset are summarized for each tank in Table 4.6, in descending order of percent TOC.

Table 4.4. TOC Measurement Counts, Raw Data (Wet Basis)

\begin{tabular}{||l|c|c|c||}
\hline & Liquids & Solids & Total \\
\hline All Data & 150 & 73 & 223 \\
\hline$>1$ percent TOC & 24 & 11 & 35 \\
\hline$>2$ percent TOC & 13 & 9 & 22 \\
\hline$>3$ percent TOC & 9 & 6 & 15 \\
\hline$>4$ percent TOC & 6 & 3 & 9 \\
\hline$>5$ percent TOC & 6 & 2 & 8 \\
\hline
\end{tabular}


Table 4.5. Distribution of TOC Measurement Values (Wet) Across Tanks

\begin{tabular}{|c|c|l|}
\hline $\begin{array}{c}\text { TOC Concentration, } \\
\text { (wet wt\%) }\end{array}$ & $\begin{array}{c}\text { Number of } \\
\text { Tanks }\end{array}$ & \multicolumn{1}{|c|}{ Tank Identification } \\
\hline$>5 \%$ & 4 & A101, SX106, T104, C106 \\
$4-5 \%$ & 1 & SX103 \\
$3-4 \%$ & 5 & B202, TX118, C103, C105, C111 \\
$2-3 \%$ & 4 & AX102, AX103, S102, S111 \\
\hline $1-2 \%$ & 6 & A103, AX101, BX112, BY104, S110, TY105 \\
\hline$<1 \%$ & 55 & (All Others) \\
\hline
\end{tabular}

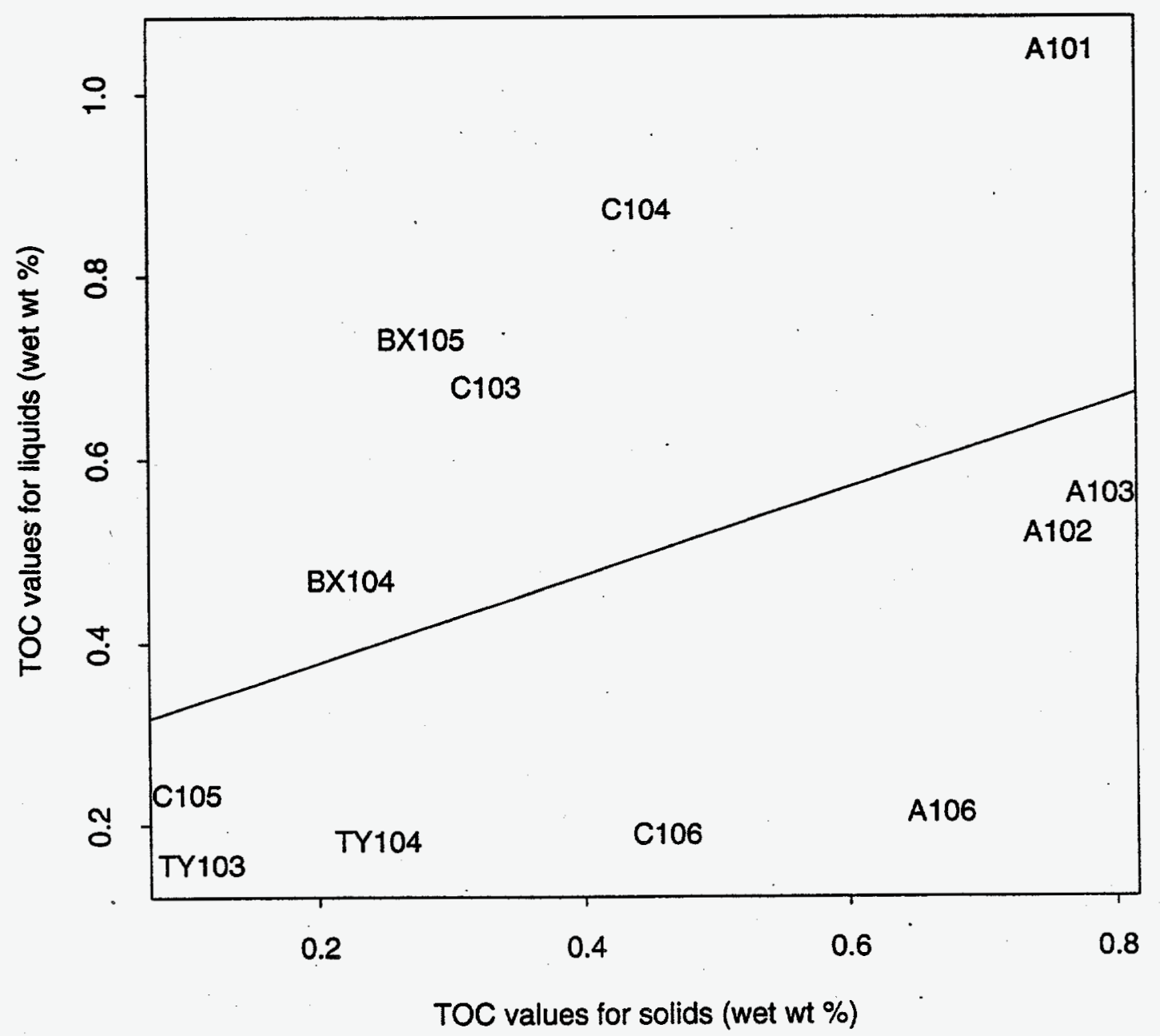

Figure 4.3. Laboratory TOC Measurements (Wet) Versus Waste Type, Liquid or Solid, for Selected - SSTs 
Table 4.6. Estimate of Percent TOC (Dry) for 149 Single-Shell Tanks According to the TRAC Dataset, in Descending Order of TOC

\begin{tabular}{||l|c|l|c|l|c||}
\hline $\begin{array}{c}\text { Tank } \\
\text { Total }\end{array}$ & $\begin{array}{c}\text { TOC, wt } \\
\text { (dry) }\end{array}$ & $\begin{array}{c}\text { Tank } \\
\text { Total }\end{array}$ & $\begin{array}{c}\text { TOC, wt\% } \\
\text { (dry) }\end{array}$ & $\begin{array}{c}\text { Tank } \\
\text { Total }\end{array}$ & $\begin{array}{c}\text { TOC, wt } \\
\text { (dry) }\end{array}$ \\
\hline SX-106* & 5.02 & BY-102 & 0.23 & B-204 & 0.00 \\
\hline TX-105* & 4.94 & B-108 & 0.21 & BX-107 & 0.00 \\
\hline U-107* & 4.81 & C-107 & 0.20 & C-106 & 0.00 \\
\hline C-112 & 4.27 & B-106 & 0.18 & C-201 & 0.00 \\
\hline C-109 & 3.52 & C-108 & 0.16 & C-202 & 0.00 \\
\hline B-103* & 3.17 & S-109 & 0.14 & C-203 & 0.00 \\
\hline B-102 & 2.87 & B-109 & 0.11 & C-204 & 0.00 \\
\hline TX-109 & 2.45 & TX-102 & 0.07 & S-104 & 0.00 \\
\hline AX-103 & 2.30 & U-102 & 0.07 & S-105 & 0.00 \\
\hline A-103 & 2.27 & S-106 & 0.03 & SX-107 & 0.00 \\
\hline SX-105 & 2.07 & BY-103 & 0.02 & SX-108 & 0.00 \\
\hline BY-110 & 1.91 & B-101 & 0.01 & SX-109 & 0.00 \\
\hline C-105 & 1.88 & TX-112 & 0.01 & SX-111 & 0.00 \\
\hline TX-110 & 1.87 & T-108 & 0.01 & SX-112 & 0.00 \\
\hline BY-105 & 1.84 & BX-109 & 0.00 & SX-113 & 0.00 \\
\hline BX-105 & 1.73 & BX-101 & 0.00 & SX-114 & 0.00 \\
\hline BX-110 & 1.72 & B-111 & 0.00 & SX-115 & 0.00 \\
\hline BX-111 & 1.71 & TY-104 & 0.00 & T-104 & 0.00 \\
\hline BY-108 & 1.70 & BX-103 & 0.00 & T-106 & 0.00 \\
\hline BY-104 & 1.67 & SX-102 & 0.00 & T-110 & 0.00 \\
\hline B-112 & 1.60 & BX-104 & 0.00 & T-111 & 0.00 \\
\hline BY-111 & 1.46 & SX-101 & 0.00 & T-112 & 0.00 \\
\hline BX-102 & 1.43 & B-107 & 0.00 & T-201 & 0.00 \\
\hline BY-107 & 1.30 & T-109 & 0.00 & T-202 & 0.00 \\
\hline A-102 & 1.28 & AX-101 & 0.00 & T-203 & 0.00 \\
\hline TY-103 & 1.23 & S-102* & 0.00 & T-204 & 0.00 \\
\hline T-101 & 1.18 & TX-101 & 0.00 & TX-106 & 0.00 \\
\hline
\end{tabular}


Table 4.6. (contd)

\begin{tabular}{||l|c|l|c|c|c||}
\hline $\begin{array}{c}\text { Tank } \\
\text { Total }\end{array}$ & $\begin{array}{c}\text { TOC, wt\% } \\
\text { (dry) }\end{array}$ & $\begin{array}{c}\text { Tank } \\
\text { Total }\end{array}$ & $\begin{array}{c}\text { TOC, wt\% } \\
\text { (dry) }\end{array}$ & $\begin{array}{c}\text { Tank } \\
\text { Total }\end{array}$ & $\begin{array}{c}\text { TOC, wt\% } \\
\text { (dry) }\end{array}$ \\
\hline BY-106 & 1.14 & C-101 & 0.00 & TX-107 & 0.00 \\
\hline T-102 & 1.11 & U-106* & 0.00 & TX-108 & 0.00 \\
\hline BY-101 & 1.11 & BX-108 & 0.00 & TX-113 & 0.00 \\
\hline C-111 & 1.08 & A-107 & 0.00 & TX-114 & 0.00 \\
\hline B-110 & 0.99 & TX-104 & 0.00 & TX-115 & 0.00 \\
\hline SX-103 & 0.72 & A-105 & 0.00 & TX-116 & 0.00 \\
\hline B-202 & 0.70 & A-106 & 0.00 & TX-117 & 0.00 \\
\hline S-111 & 0.69 & SX-110 & 0.00 & TY-101 & 0.00 \\
\hline S-108 & 0.66 & S-103* & 0.00 & TY-105 & 0.00 \\
\hline TX-118* & 0.63 & C-104 & 0.00 & TY-106 & 0.00 \\
\hline BX-106 & 0.61 & C-103 & 0.00 & U-101 & 0.00 \\
\hline S-110 & 0.54 & C-110 & 0.00 & U-103 & 0.00 \\
\hline TY-102 & 0.49 & AX-102 & 0.00 & U-104 & 0.00 \\
\hline S-101 & 0.49 & T-107 & 0.00 & U-105 & 0.00 \\
\hline TX-111 & 0.45 & BX-112 & 0.00 & U-108 & 0.00 \\
\hline S-112 & 0.40 & T-105 & 0.00 & U-109 & 0.00 \\
\hline TX-103 & 0.35 & C-102 & 0.00 & U-110 & 0.00 \\
\hline BY-112 & 0.33 & A-104 & 0.00 & U-112 & 0.00 \\
\hline T-103 & 0.31 & A-101 & 0.00 & U-201 & 0.00 \\
\hline AX-104 & 0.30 & B-104 & 0.00 & U-202 & 0.00 \\
\hline U-111* & 0.24 & B-105 & 0.00 & U-203 & 0.00 \\
\hline BY-109 & 0.24 & B-201 & 0.00 & U-204 & 0.00 \\
\hline SX-104 & 0.23 & B-203 & 0.00 & & \\
\hline$*$ Original organic watchlist tank. & & & \\
\hline
\end{tabular}




\subsection{Relationship of TOC to Other Variables in the Dataset}

Some important observations can be made about the data and present sources of skew which impact the best estimates of TOC for each tank. The TOC measurements plotted against time indicate higher laboratory measurements were obtained in the years prior to 1985 . Figure 4.4 displays the laboratory measurements according to when it was recorded. A quantitative documented basis why pre-1985 TOC data contain higher TOC values than post-1985 data could not be established. It should be noted that the selection criteria for identifying which tanks to sample may have had an impact on the higher TOC values in earlier years.

TOC measurement techniques were examined in an attempt to explain the pre-1985 TOC data. All the TOC determinations used in the laboratory were based on oxidation of organics and detection of the $\mathrm{CO}_{2}$ gas by either infrared (IR) or coulometric measurement systems. The IR system is very sensitive with a limited dynamic range and requires large dilutions of the samples before analysis. One problem with the system that would account for the larger values in earlier years is that the high sodium in the samples is very detrimental to the furnace tubes. One of the problems with old data is that it did not include any quality control information such as blanks, spikes standards or duplicates to determine if the instrument was operating "properly." The high sensitivity and large dilutions required by this method can magnify the effect of TOC contamination. Furnace oxidation systems also have the disadvantage that they produce other gases $\left(\mathrm{NO}_{\mathrm{x}}, \mathrm{SO}_{2}\right.$, etc.) which potentially could interfere in the method if 1) they are not adequately trapped or 2) the IR detector selectivity is inadequate to differentiate between $\mathrm{CO}_{2}$ and the other gas. Sometimes TOC is determined by the difference between the total carbon (TC) and the total inorganic carbon (TIC): TOC = TC - TIC. This can result in additional errors caused by the difference of two large numbers.

Measurement method was investigated as an additional source of variance to see if a relationship between measurement method and reported TOC concentration unit exists. This is summarized in Table 4.7. A disproportionate number of high observations were reported in units of moles/L. Although it does not seem to be coincidence, an explanation of this association was not found. 


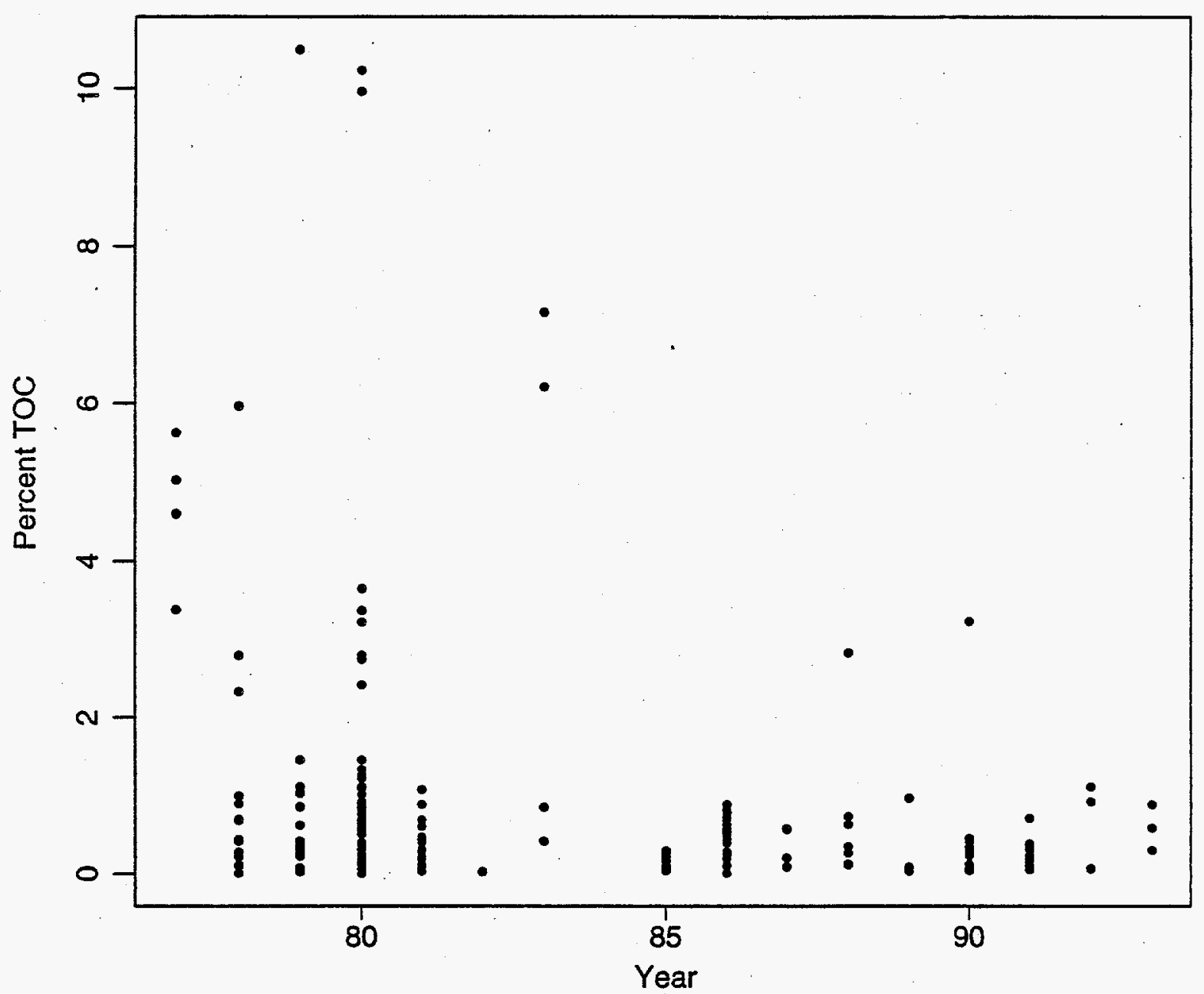

Figure 4.4. Percent TOC Measurements (Wet) Plotted Against the Year of the Document in Which the Measurement Was Reported 
Table 4.7. TOC (Wet) Observations and Measurement Units Reported

\begin{tabular}{||l|c|c||}
\hline Reporting Units & $\%$ TOC $<2 \%$ & $\%$ TOC $>2 \%$ \\
\hline gm/gm & 9 & 3 \\
\hline gm/L & 120 & 6 \\
\hline moles/L & 13 & 7 \\
\hline ug/g & 2 & 0 \\
\hline ugm/gm & 28 & 0 \\
\hline wt $\%$ & 30 & 5 \\
\hline
\end{tabular}

\subsection{Distributional Assumptions}

ANOVA makes fairly specific assumptions about the distribution of the data (i.e., the effects are normally distributed, with constant variance). While the violation of these assumptions may not strongly affect some ANOVA results (for example the estimate of the mean), the distributional assumptions are very important. To assign uncertainties to the tank estimates the distributions implied by the ANOVA models should be accurately represented from the data available. In this analysis it is assumed that all data, in each laboratory measurement, is weighted equally.

To examine the distribution of the data, Quantile-Quantile (Q-Q) plots of the TOC data were made. For the TOC data, the Q-Q plot locates the data relative to its standard normal distribution. A normal distribution is displayed as points following a straight line. Figure 4.5 displays a Q-Q plot of the TOC data from the dataset. From the figure, it is apparent that the data is skewed, with a heavy left-hand tail; the data does not seem to be normally distributed. Of course, this data contains several difference sources of variability, in different amounts, and this may be causing the effects. To see if the data could be made normal by a transformation, a Q-Q plot of the logged TOC data is given in Figure 4.6 and the plot, although not exactly linear, is much better with a correlation coefficient of 0.98 . This Q$Q$ plot gives a strong indication that logged TOC data would fit the normal-distribution assumptions of ANOVA models much better than the unlogged data. Similar improved results are obtained by taking the log of the components of Equation 4.1, indicating a log-normal distribution.

A log transformation can be explained further. The logged model produces positive values, while the unlogged model allows the data to be negative, which is not possible for TOC data. Also, the logged model extrapolates to large TOC values in a more conservative manner. Since most of the TOC measurements in the tank are fairly low (i.e., much less than 5\%), the logged models will assign higher variabilities to large values than an unlogged model would. (In a logged ANOVA model, the standard deviations will be proportional to the mean, but in unlogged models, the standard deviations are constant). Therefore, a logged model should produce more conservative prediction intervals than an unlogged model. 
The distribution of the effects (on the unlogged) scale are also skewed, with a heavy right-hand distribution. Since distributions with heavy right-hand tails will give more conservative exceedance probabilities than symmetric distributions, this aspect of the log transformation produces conservative estimates. It is important to note that since the distributions are skewed, the ANOVA estimates being produced (on the unlogged scale) are no longer best estimates for distribution means; The ANOVA estimates are best estimates for distribution medians. Taking the exponential value of the mean logarithm TOC transforms the value into the median TOC. However, taking the exponential value of the sum of the mean logarithm TOC plus an error correction term transforms the value into the mean TOC. This is shown in equations 4.2 through 4.5.

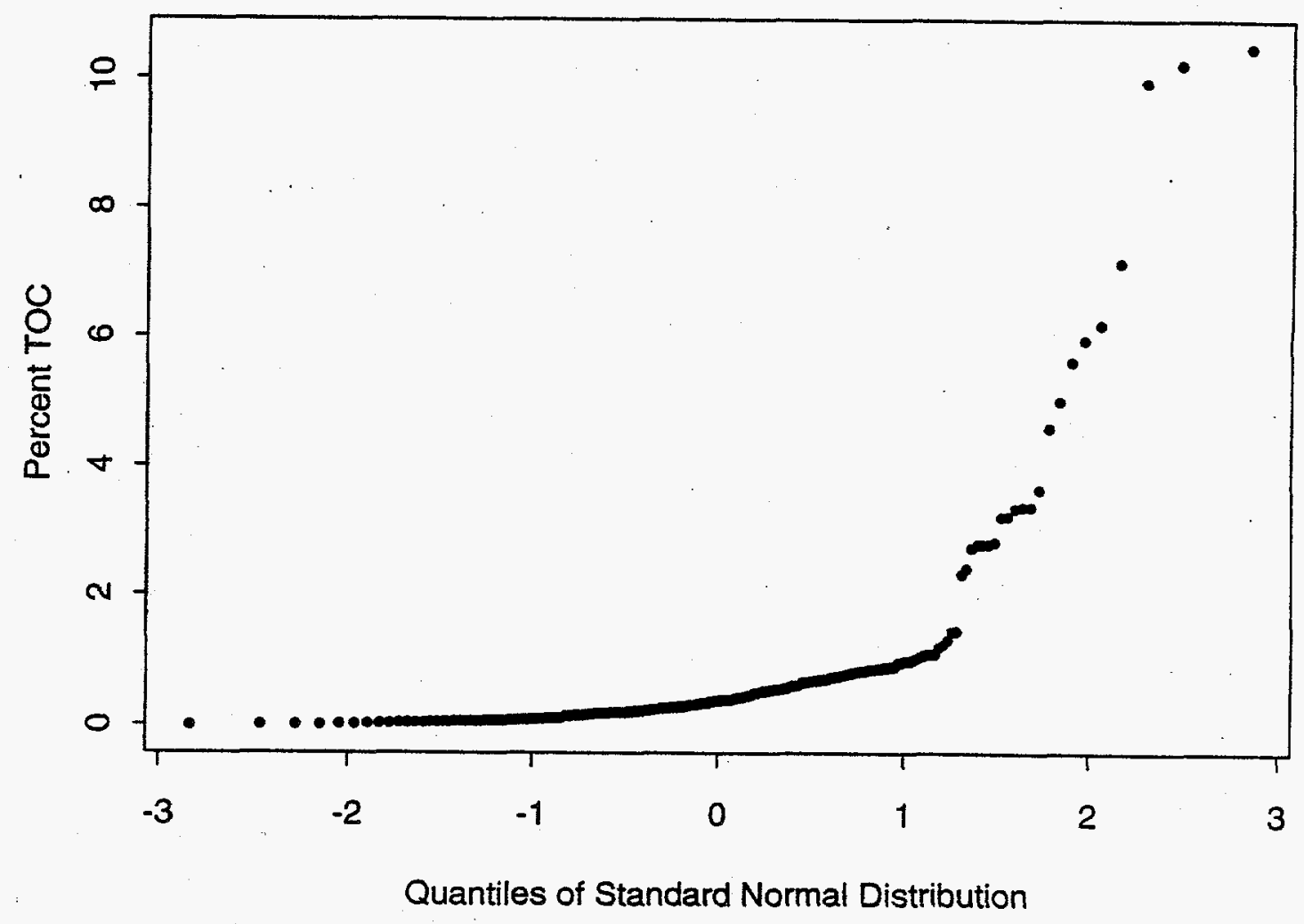

Figure 4.5. Q-Q Plot of Untransformed Laboratory TOC Measurements 


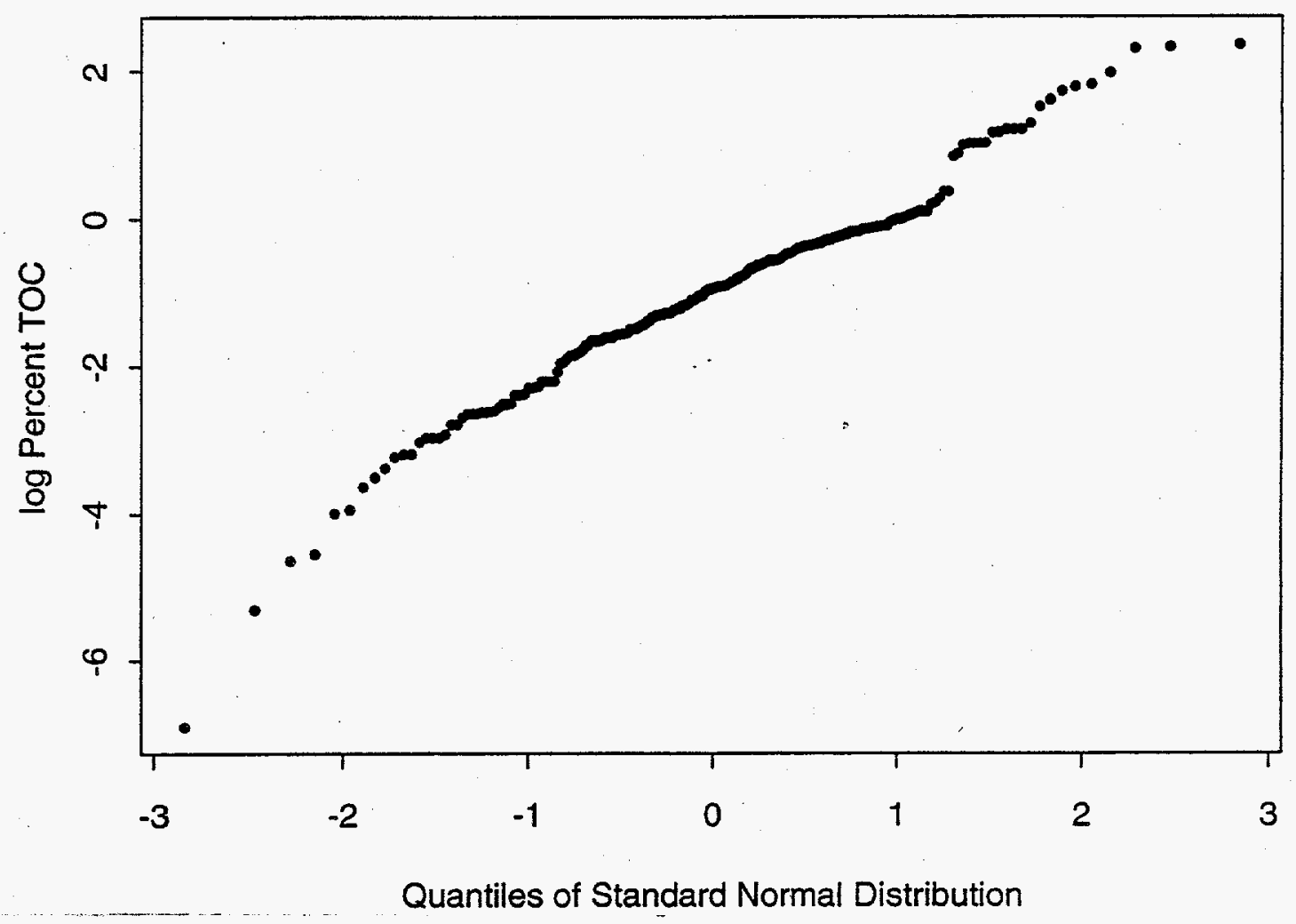

Figure 4.6. Q-Q Plot of the Logarithm of the Laboratory TOC Measurements

\subsection{Factors Included in the ANOVA Analysis}

In the TOC data, the sample was classified as a sludge, saltcake, or liquid sample. Since no direct correlation between solid and liquid values was found, as shown in Section 4.2, a waste type term was not included in the ANOVA technique.

The SORWT model groups tanks of similar waste type. The SORWT group was evaluated to identify if it was a significant factor. Plots of TOC verses SORWT group did not indicate that SORWT group was highly correlated with TOC, but it was apparent that a relationship existed. A simple ANOVA fit confirmed that SORWT group is a significant factor, so it was included in the ANOVA model.

As a result, the ANOVA model utilized was:

$$
\log \left(\operatorname{TOC}_{\mathrm{ijk}}\right)=\mathrm{u}+\mathrm{G}_{\mathrm{i}}+\mathrm{T}_{\mathrm{ij}}+\mathrm{E}_{\mathrm{ijk}}
$$


where $\exp (u)$ is the median TOC value for all Hanford waste, $\exp \left(u+G_{i}\right)$ is the median TOC value for the SORWT group $i$, the term $\exp \left(u+G_{i}+T_{i j}\right)$ is the median TOC in tank $i j$, and the term $E_{i j k}$ represents the within tank variability. The ANOVA model does not explicitly treat the spatial distribution or laboratory measurement error directly. These two effects are included in the $E_{\mathrm{ijk}}$ term of the ANOVA model which represent the residual error term. The ANOVA results produce standard errors (standard deviations) for all the estimates used in the above formula, so it is possible to calculate an uncertainty associated with the tank estimate. The ANOVA model produces estimates for the variability associated with each effect.

The ANOVA results can be used to assess the wet basis TOC for each tank. If the particular tank of interest is represented in the dataset, then one can consider the following estimates for TOC content;

$$
\text { Median TOC Content in Tank } i j=\exp \left(u+G_{i}+T_{i j}\right)
$$

or, if the mean is desired,

$$
\text { Mean TOC content in the tank } i j=\exp \left(u+G_{i}+T_{i j}+0.5 \sigma_{E}^{2}\right)
$$

where $\sigma_{\mathrm{E}}=$ standard deviation of residuals $\mathrm{E}$.

If the tank is not present in the dataset, but is known to be a member of SORWT group $i$, then the best estimate for its contents are

$$
\text { Median TOC Content in Tank } \mathrm{ij}=\exp \left(\mathrm{u}+\mathrm{G}_{\mathrm{i}}\right)
$$

or, if the mean is desired,

$$
\text { Mean TOC content in the Tank } \mathrm{ij}=\exp \left[\mathrm{u}+\mathrm{G}_{\mathrm{i}}+0.5 *\left(\sigma_{\mathrm{T}}^{2}+\sigma_{\mathrm{E}}^{2}\right)\right]
$$

where $\sigma_{\mathrm{T}}$ is the standard deviation for the tank-to-tank factor $\mathrm{T}$ and $\sigma_{\mathrm{E}}$ represents the standard deviation for the residuals term. 
The median is used to provide a best estimate of TOC for all the tanks. The decision to select the median as a best estimate for TOC is based on the assumption that the residuals error term is based on measurement error as the key contributor. The mean value would be a better assessment of the TOC if the spatial distributions within the tank are a greater contributor to error than the measurement error.

The ANOVA model described in Equation 4.1 is a random effects model. That is, the terms G(i) and $\mathrm{T}(\mathrm{ij})$ are assumed to be normally distributed random variables. The assumption that these terms are random effects provides enough information to allow us to estimate TOC in tanks with no measurements. The alternative to this assumption would be to assume that these terms are fixed effects: i.e., the terms $\mathrm{G}(\mathrm{i})$ and $\mathrm{T}(\mathrm{ij})$ represent unknown parameters that must be estimated from the data. If this perspective would be adopted, then nothing could be assumed about unsampled tanks, but the ANOVA fit will produce a description of the data using less modeling assumptions. The random effects model used to assess the TOC in each tank utilizes the characteristic information known about the tanks. The tank estimates tend to be shrunk towards the group means.

\subsection{Conversion of TOC to Dry Basis}

To be consistent with the organic safety watchlist criteria, the TOC assessments from the ANOVA model must be converted to a dry basis. The conversion utilized the ANOVA TOC assessment values and information from the Westinghouse Hanford Company Tank Waste Surveillance reports (Hanlon 1993). The total inventory of organic carbon is calculated using the following equation:

$$
\mathrm{T}_{\mathrm{ij}}(\mathrm{toc})=\% \mathrm{TOC}(\mathrm{wet}) * \mathrm{M}(\mathrm{tank})
$$

where $\mathrm{T}_{\mathrm{ij}}$ (toc) $=$ total amount of organic carbon in the tank $\mathrm{ij}$.

$\%$ TOC(wet) $=\%$ TOC from ANOVA analysis

$M(\operatorname{tank})=$ total mass of the tank inventory, $(\mathrm{kg})$, from Tank Farm Surveillance report.

The dry basis mass for the SSTs is determined by knowing the volume of sludge and saltcake in each tank. It is assumed $60 \%$ of the sludge volume is water, and $40 \%$ of the saltcake volume is water. Therefore, the following equation is used to estimate the dry volume is each tank:

$$
\mathrm{V}(\mathrm{dry})=0.4 * \text { (sludge volume })+0.6 * \text { (saltcake volume })
$$

where $\mathrm{V}(\mathrm{dry})=$ dry volume of tank, thousand gallon. 
The $\mathrm{V}$ (dry) is converted to $\mathrm{M}$ (dry), dry mass assuming an overall density of $1.3 \mathrm{gm} /$ cubic centimeter.

The Dry Basis TOC is calculated using the following ratio:

$$
\text { Percent dry basis TOC }=100 * \mathrm{~T}(\mathrm{ij}) \text { (toc) } / \mathrm{M}(\mathrm{dry})
$$

The wet-to-dry correction factor is calculated as follows:

$$
\mathrm{C}_{\mathrm{w} / \mathrm{D}}=\frac{\text { TOC (dry basis) }}{\text { TOC (wet basis) }}
$$

The correction factors for all tanks are provided in Table A.4 in Appendix A.

\subsection{Results of Fits to TOC Data}

The combined data consists of 223 measurements on 75 tanks. Most tanks in the dataset have more than two TOC measurements associated with them, but a few (18) have more than 4 . The most heavily sampled tank in the dataset is A-101, with 17 TOC measurements. Although SORWT grouping is used in this analyses, it is not ideal. There are too many SORWT groups with data on only one tank (14). Plus some of the tanks with data are ungrouped.

The ANOVA fit produces estimates for all three dataset alternatives using the model parameters listed in Table 4.8. These estimates apply to a logged scale, so the sigma estimates are converted to unlogged relative standard deviations (RSDs).

The tables give us important information about how good the SORWT grouping is in predicting TOC content in a tank. If SORWT grouping were highly effective, the between group standard deviation would be much larger than the other two sources of variability, between tank and within tank standard deviation. One can see that this is definitely not the case; in fact, within tank variability is the largest source of variability for the entire dataset. This will have important implications for an efficient estimation formula for tank TOC content. Since an individual tank measurement displays so much variability, it is most efficient to use information about the group to estimate what is in an individual tank. In fact, this is just what the ANOVA does.

Best estimates for each SORWT group using the ANOVA method are provided in Table 4.9.

The estimators for tank TOC that the ANOVA logarithmic model produces are weighted averages of the overall mean, the group mean, and the tank mean (on the scale). This causes the estimate to be 
weighted towards the overall group mean. The amount of weighting towards the overall mean, or shrinkage, is displayed by the estimator and reflects the variabilities present in each the tank's data. Figures 4.7, 4.8, and 4.9 represent how the estimates for each group $u+G_{i}$ and each tank $u+G_{i}+$ $\mathrm{T}_{\mathrm{ij}}$ are shrunk towards the mean for both datasets. In these figures, the solid dots represent the laboratory measurements associated with the tank, the " $\mathrm{f}$ " represents the fixed effect tank estimate, and the circle the random effects estimate, and finally the vertical line the group estimate. From this plot, one can see how much the random effects estimate is shrunk towards the group mean. For a tank like S110, with only one laboratory measurement, we can see that the shrinkage is substantial; for a tank like A101 with 17 laboratory measurements, the shrinkage is very small.

Table 4.10 presents the best estimate TOC values for all 149 SSTs (median estimates, wet basis). Table 4.11 presents mean estimates for each tank on a wet basis. Table 4.12 and 4.13 present median and mean results for each SST on a dry basis. Tanks without a SORWT group listed indicate the tank is ungrouped. The logarithm values are included in these tables for use by other organic analyses and follow-on studies.

The fits produced on Table 4.10 are used to give best estimates of the average dry weight TOC concentrations in each SST. To obtain such an estimate, two correction factors must be used. First, the median result must be transformed to mean estimates. Secondly, the estimate must be transformed to dry weight units. Both of these corrections involve a multiplication by a correction factor.

The correction factor for transforming the median estimate to an average is given by:

$\frac{1}{2} \sigma_{\mathrm{E}}^{2}=1.85$ if the tank has been sampled

$\exp \left[\frac{1}{2}\left(\sigma_{\mathrm{G}}^{2}+\sigma_{\mathrm{T}}^{2}+\sigma_{\mathrm{E}}^{2}\right)\right]=2.50$ if neither the tank nor the group it belongs to was sampled $\exp \left[\frac{1}{2}\left(\sigma_{\mathrm{T}}^{2}+\sigma_{\mathrm{E}}^{2}\right)\right]=\begin{aligned} & 2.40 \text { if the tank was not sampled but is a member of a SORWT group } \\ & \text { which was sampled }\end{aligned}$

The wet median and mean TOC values are transformed to a dry basis by multiplying the values by the wet to dry correction factor provided in Table A.4 in Appendix A. 
Table 4.8. Estimates of ANOVA Model Parameters (logged) for the Laboratory Dataset

\begin{tabular}{||l|r|c|c|}
\hline \multicolumn{1}{|c|}{ Parameter } & Estimate & SD $^{(\mathrm{a})}$ (estimate) & RSD \\
\hline Mean, $\mathrm{u}$ & -1.137 & 0.019 & $\mathrm{NA}$ \\
\hline $\begin{array}{l}\text { Between Group Standard } \\
\text { Deviation (SD) } \mathrm{G}_{\mathrm{i}}\end{array}$ & 0.080 & 0.143 & 0.080 \\
\hline Between Tank SD T & 0.519 & 0.210 & 0.556 \\
\hline Within Tank SD E & 1.232 & 0.140 & 1.887 \\
\hline \hline Eijk & (a) SD = Standard Deviation. \\
\hline
\end{tabular}

Table 4.9. Best Estimates for Each SORWT Group (wet \% weight)

\begin{tabular}{|c|ccc|}
\hline SORWT Group & $\mu+G_{i}$ & Median & Mean \\
\hline 1 & $-0.93 \pm 0.22$ & 0.40 & 0.44 \\
2 & $-1.22 \pm 0.26$ & 0.29 & 0.34 \\
3 & $-1.14 \pm 0.27$ & 0.32 & 0.37 \\
4 & $-1.11 \pm 0.27$ & 0.33 & 0.38 \\
5 & $-1.19 \pm 0.29$ & 0.30 & 0.35 \\
6 & $-1.14 \pm 0.30$ & 0.32 & 0.37 \\
7 & $-0.96 \pm 0.27$ & 0.38 & 0.44 \\
8 & $-1.19 \pm 0.29$ & 0.30 & 0.35 \\
9 & $-0.90 \pm 0.25$ & 0.41 & 0.46 \\
10 & $-0.99 \pm 0.30$ & 0.37 & 0.43 \\
11 & $-1.27 \pm 0.30$ & 0.28 & 0.33 \\
12 & $-1.10 \pm 0.30$ & 0.33 & 0.39 \\
13 & $-1.16 \pm 0.31$ & 0.31 & 0.37 \\
14 & $-1.16 \pm 0.31$ & 0.31 & 0.37 \\
15 & $-1.23 \pm 0.31$ & 0.29 & 0.34 \\
16 & $-1.08 \pm 0.31$ & 0.34 & 0.40 \\
17 & $-1.31 \pm 0.30$ & 0.27 & 0.31 \\
19 & $-1.22 \pm 0.31$ & 0.30 & 0.35 \\
21 & $-1.18 \pm 0.29$ & 0.31 & 0.36 \\
22 & $-1.16 \pm 0.29$ & 0.31 & 0.36 \\
23 & $-1.12 \pm 0.28$ & 0.32 & 0.37 \\
24 & $-1.20 \pm 0.29$ & 0.30 & 0.35 \\
25 & $-1.19 \pm 0.29$ & 0.30 & 0.35 \\
26 & $-1.15 \pm 0.30$ & 0.32 & 0.37 \\
27 & $-1.30 \pm 0.28$ & 0.27 & 0.31 \\
28 & $-0.93 \pm 0.29$ & 0.39 & 0.45 \\
\hline & & & \\
\hline
\end{tabular}




\section{Lognormal Model Fit}

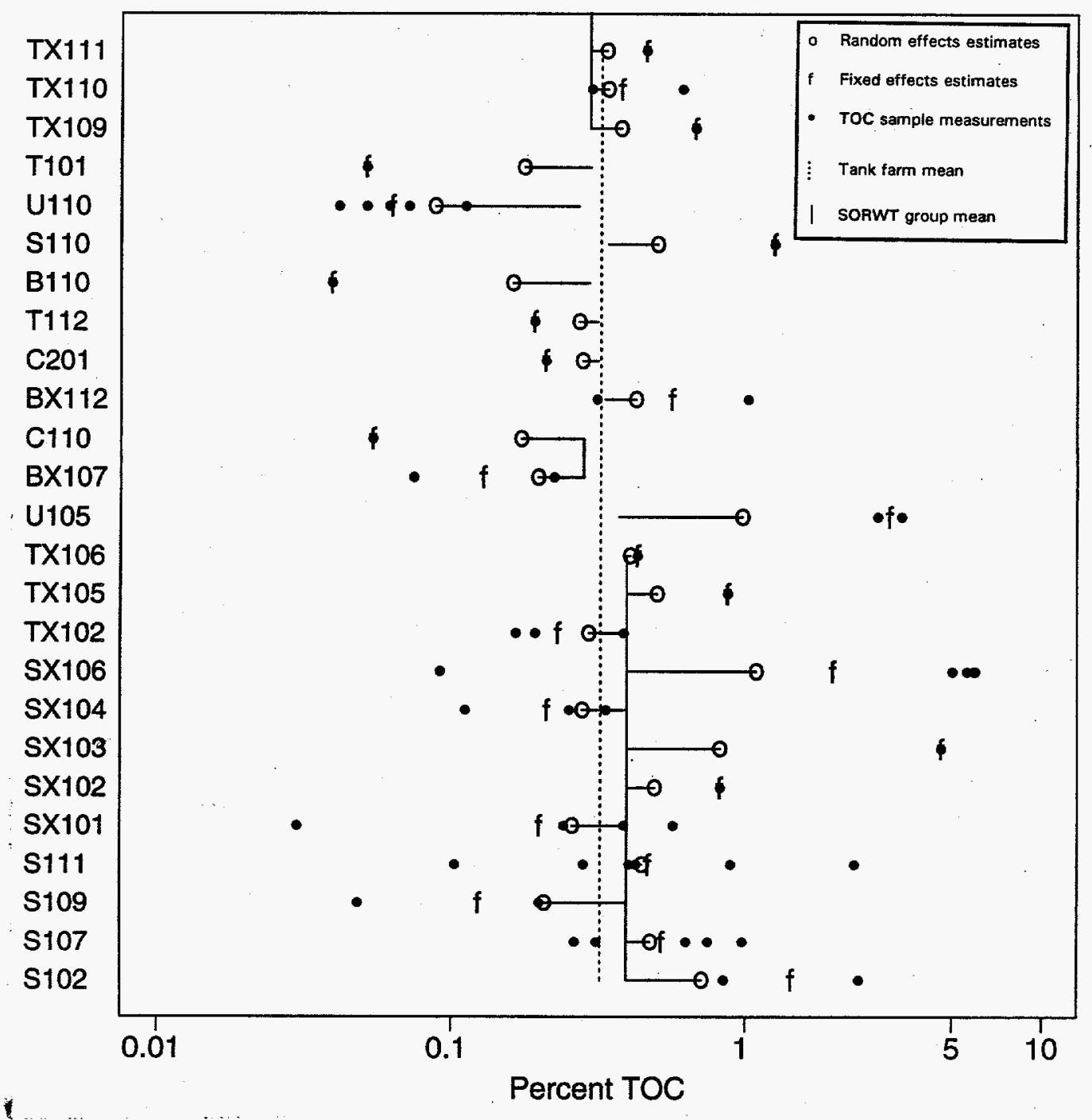

Figure 4.7. Estimated Effects (Wet Data) from ANOVA Model 
Lognormal Model Fit

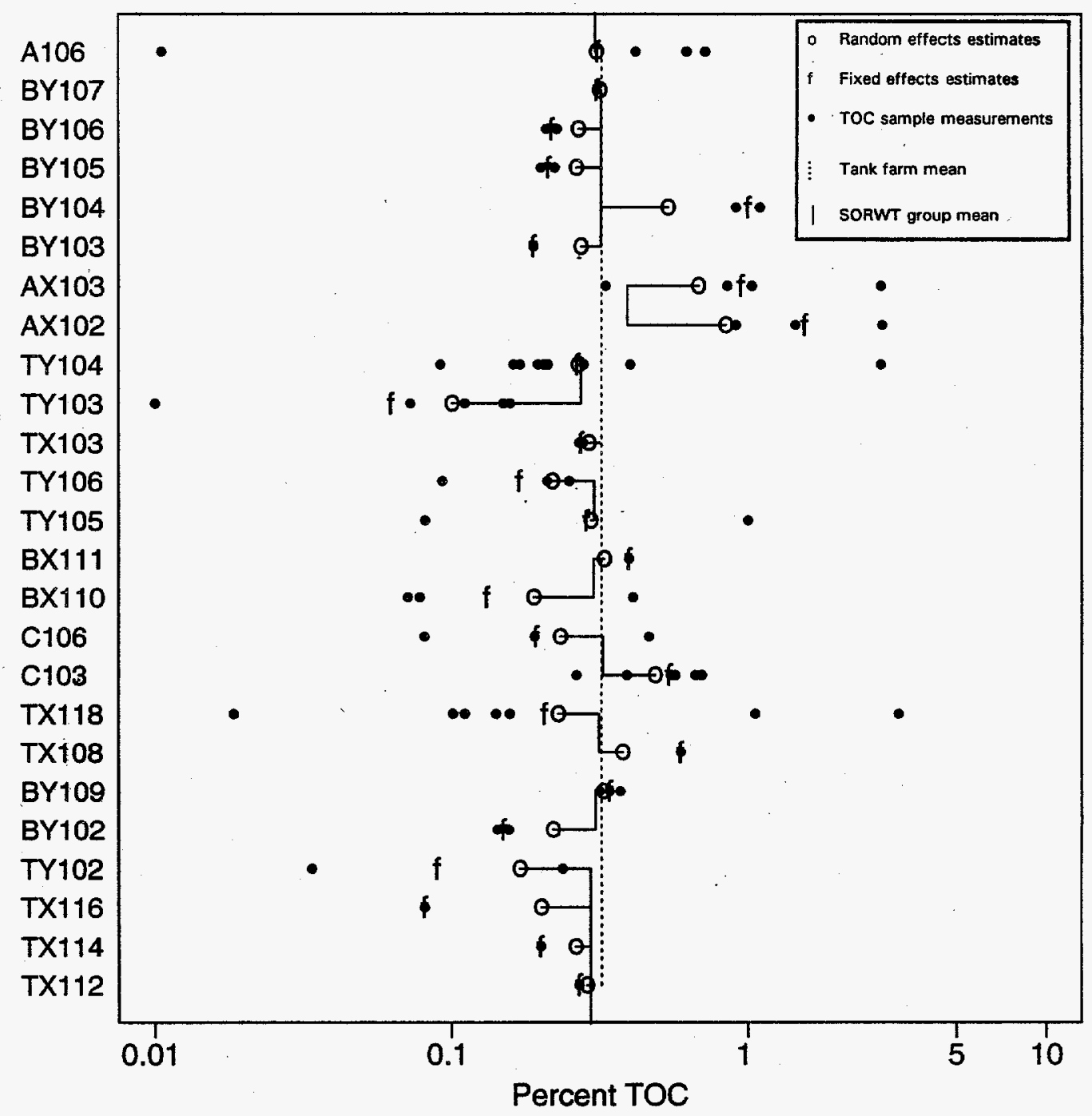

Figure 4.8. Estimated Effects (Wet Data) from ANOVA Model (continued) 


\section{Lognormal Model Fit}

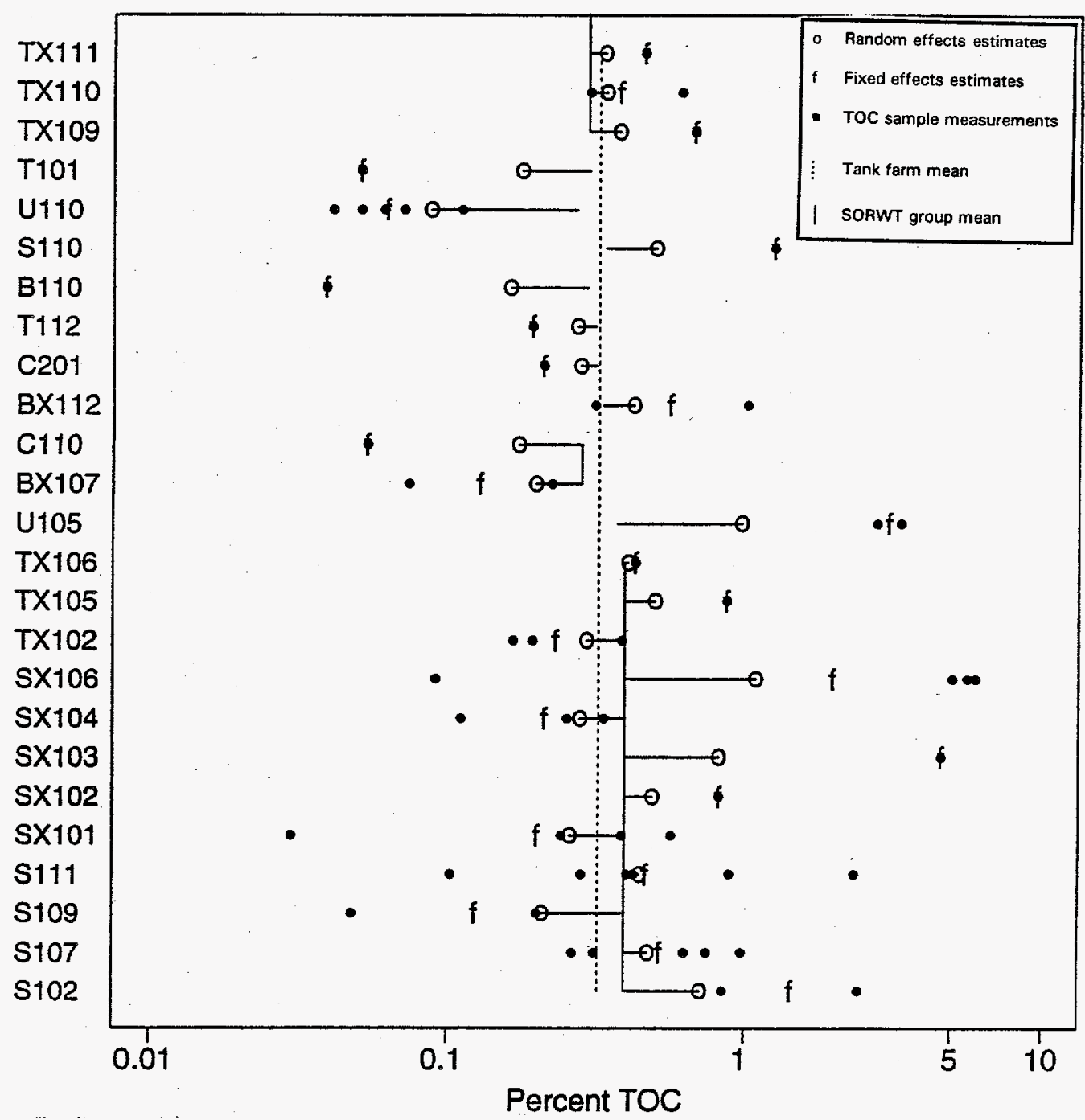

Figure 4.9. Estimated Effects (Wet Data) from ANOVA Model (continued) 
Table 4.10. TOC Wet Units, Median Estimate

\begin{tabular}{|c|c|c|c|c|c|}
\hline Tank & $\begin{array}{l}\text { SORWT } \\
\text { Number } \\
\end{array}$ & $\begin{array}{l}\text { Mean Log } \\
\text { TOC }\end{array}$ & $\begin{array}{l}\text { SD Log } \\
\text { TOC }\end{array}$ & $\begin{array}{l}\text { Median TOC } \\
\text { wet \% }\end{array}$ & $\begin{array}{l}95 \% \text { Confidence } \\
\text { Limit } \\
\end{array}$ \\
\hline SX106* & 1 & 0.08 & 0.45 & 1.09 & 2.27 \\
\hline $\mathrm{A} 101$ & 9 & 0.06 & 0.25 & 1.06 & 1.61 \\
\hline U106* & 7 & 0.01 & 0.63 & 1.01 & 2.86 \\
\hline U105 & 10 & -0.02 & 0.56 & 0.98 & 2.44 \\
\hline $\mathrm{AX} 102$ & 28 & -0.17 & 0.5 & 0.85 & 1.91 \\
\hline T104 & 30 & -0.17 & 0.49 & 0.84 & 1.88 \\
\hline SX103 & 1 & -0.2 & 0.62 & 0.82 & 2.28 \\
\hline $\mathrm{U} 103$ & 7 & -0.33 & 0.55 & 0.72 & 1.78 \\
\hline S102* & 1 & -0.34 & 0.54 & 0.71 & 1.74 \\
\hline AX103 & 28 & -0.38 & 0.45 & 0.68 & 1.44 \\
\hline AX101 & 9 & -0.4 & 0.42 & 0.67 & 1.33 \\
\hline U111* & 7 & -0.42 & 0.49 & 0.66 & 1.48 \\
\hline A103 & 9 & -0.5 & 0.35 & 0.61 & 1.08 \\
\hline BY104 & 3 & -0.62 & 0.55 & 0.54 & 1.33 \\
\hline $\mathbf{S 1 1 0}$ & 16 & -0.69 & 0.64 & 0.5 & 1.44 \\
\hline TX105* & 1 & -0.69 & 0.62 & 0.5 & 1.4 \\
\hline SX102 & 1 & -0.71 & 0.62 & 0.49 & 1.37 \\
\hline C103* & 23 & -0.72 & 0.33 & 0.49 & 0.85 \\
\hline $\mathbf{S 1 0 7}$ & 1 & -0.74 & 0.41 & 0.48 & 0.94 \\
\hline S111 & 1 & -0.81 & 0.39 & 0.45 & 0.84 \\
\hline BX112 & 12 & -0.86 & 0.56 & 0.42 & 1.06 \\
\hline $\mathrm{C} 104$ & 30 & -0.86 & 0.55 & 0.42 & 1.04 \\
\hline C112 & 8 & -0.88 & 0.5 & 0.41 & 0.93 \\
\hline TX106 & 1 & -0.9 & 0.62 & 0.41 & 1.13 \\
\hline $\mathrm{S} 101$ & 1 & -0.93 & 0.75 & 0.4 & 1.36 \\
\hline S103 & 1 & -0.93 & 0.75 & 0.4 & 1.36 \\
\hline S105 & 1 & -0.93 & 0.75 & 0.4 & 1.36 \\
\hline S106 & 1 & -0.93 & 0.75 & 0.4 & 1.36 \\
\hline S108 & 1 & -0.93 & 0.75 & 0.4 & 1.36 \\
\hline S112 & 1 & -0.93 & 0.75 & 0.4 & 1.36 \\
\hline SX105 & 1 & -0.93 & 0.75 & 0.4 & 1.36 \\
\hline TX104 & 1 & -0.93 & 0.75 & 0.4 & 1.36 \\
\hline TX107 & 1 & -0.93 & 0.75 & 0.4 & 1.36 \\
\hline BX105 & 4 & -0.93 & 0.45 & 0.39 & 0.83 \\
\hline
\end{tabular}


Table 4.10. (contd)

\begin{tabular}{|c|c|c|c|c|c|}
\hline Tank & $\begin{array}{l}\text { SORWT } \\
\text { Number }\end{array}$ & $\begin{array}{l}\text { Mean Log } \\
\text { TOC }\end{array}$ & $\begin{array}{l}\text { SD Log } \\
\text { TOC }\end{array}$ & $\begin{array}{l}\text { Median TOC } \\
\text { wet } \%\end{array}$ & $\begin{array}{l}95 \% \text { Confidence } \\
\text { Limit }\end{array}$ \\
\hline T204 & 5 & -0.95 & 0.64 & 0.39 & 1.1 \\
\hline $\mathrm{U} 102$ & 7 & -0.96 & 0.77 & 0.38 & 1.36 \\
\hline TX108 & 22 & -0.97 & 0.64 & 0.38 & '1.08 \\
\hline TX109 & 2 & -0.98 & 0.63 & 0.38 & 1.06 \\
\hline BX104 & 4 & -0.98 & 0.39 & 0.37 & 0.71 \\
\hline $\mathrm{U} 107 *$ & 10 & -0.99 & 0.78 & 0.37 & 1.35 \\
\hline U108 & 10 & -0.99 & 0.78 & 0.37 & 1.35 \\
\hline U109 & 10 & -0.99 & 0.78 & 0.37 & 1.35 \\
\hline SX110 & 16 & -1.08 & 0.78 & 0.34 & 1.23 \\
\hline SX111 & 16 & -1.08 & 0.78 & 0.34 & 1.23 \\
\hline SX114 & 16 & -1.08 & 0.78 & 0.34 & 1.23 \\
\hline TX110 & 2 & -1.08 & 0.49 & 0.34 & 0.76 \\
\hline SX107 & 6 & -1.08 & 0.64 & 0.34 & 0.97 \\
\hline TX111 & 2 & -1.09 & 0.63 & 0.34 & 0.95 \\
\hline BX106 & 4 & -1.11 & 0.63 & 0.33 & 0.94 \\
\hline BX101 & 4 & -1.11 & 0.77 & 0.33 & 1.17 \\
\hline BX102 & 4 & -1.11 & 0.77 & 0.33 & 1.17 \\
\hline BX103 & 4 & -1.11 & 0.77 & 0.33 & 1.17 \\
\hline $\mathrm{C} 101$ & 4 & -1.11 & 0.77 & 0.33 & 1.17 \\
\hline BX111 & 24 & -1.12 & 0.64 & 0.33 & 0.94 \\
\hline BY109 & 21 & -1.12 & 0.5 & 0.33 & 0.74 \\
\hline A104 & 30 & -1.14 & 0.79 & 0.32 & 1.17 \\
\hline A105 & 30 & -1.14 & 0.79 & 0.32 & 1.17 \\
\hline AX104 & 30 & -1.14 & 0.79 & 0.32 & 1.17 \\
\hline B101 & 18 & -1.14 & 0.79 & 0.32 & 1.17 \\
\hline B102 & 18 & -1.14 & 0.79 & 0.32 & 1.17 \\
\hline B103* & 18 & -1.14 & 0.79 & 0.32 & 1.17 \\
\hline B104 & 30 & -1.14 & 0.79 & 0.32 & 1.17 \\
\hline SX113 & 29 & -1.14 & 0.79 & 0.32 & 1.17 \\
\hline T109 & 26 & -1.14 & 0.79 & 0.32 & 1.17 \\
\hline TX101 & 30 & -1.14 & 0.79 & 0.32 & 1.17 \\
\hline U104 & 29 & -1.14 & 0.79 & 0.32 & 1.17 \\
\hline $\mathrm{U} 112$ & 30 & -1.14 & 0.79 & 0.32 & 1.17 \\
\hline U201 & 20 & -1.14 & 0.79 & 0.32 & 1.17 \\
\hline
\end{tabular}


Table 4.10. (contd)

\begin{tabular}{||l|c|c|c|c|c||}
\hline Tank & $\begin{array}{c}\text { SORWT } \\
\text { Number }\end{array}$ & $\begin{array}{c}\text { Mean Log } \\
\text { TOC }\end{array}$ & $\begin{array}{c}\text { SD Log } \\
\text { TOC }\end{array}$ & $\begin{array}{c}\text { Median TOC } \\
\text { wet \% }\end{array}$ & $\begin{array}{c}\text { 95\% Confidence } \\
\text { Limit }\end{array}$ \\
\hline U202 & 20 & -1.14 & 0.79 & 0.32 & 1.17 \\
\hline U203 & 20 & -1.14 & 0.79 & 0.32 & 1.17 \\
\hline U204 & 30 & -1.14 & 0.79 & 0.32 & 1.17 \\
\hline SX108 & 6 & -1.14 & 0.78 & 0.32 & 1.15 \\
\hline SX109 & 6 & -1.14 & 0.78 & 0.32 & 1.15 \\
\hline SX112 & 6 & -1.14 & 0.78 & 0.32 & 1.15 \\
\hline SX115 & 6 & -1.14 & 0.78 & 0.32 & 1.15 \\
\hline U101 & 6 & -1.14 & 0.78 & 0.32 & 1.15 \\
\hline BY107 & 3 & -1.15 & 0.63 & 0.32 & 0.9 \\
\hline C202 & 13 & -1.16 & 0.78 & 0.31 & 1.14 \\
\hline C203 & 13 & -1.16 & 0.78 & 0.31 & 1.14 \\
\hline C204 & 13 & -1.16 & 0.78 & 0.31 & 1.14 \\
\hline T110 & 14 & -1.16 & 0.78 & 0.31 & 1.14 \\
\hline T111 & 14 & -1.16 & 0.78 & 0.31 & 1.14 \\
\hline A106 & 30 & -1.18 & 0.39 & 0.31 & 0.59 \\
\hline B201 & 5 & -1.19 & 0.78 & 0.3 & 1.09 \\
\hline B203 & 5 & -1.19 & 0.78 & 0.3 & 1.09 \\
\hline T201 & 5 & -1.19 & 0.78 & 0.3 & 1.09 \\
\hline T202 & 5 & -1.19 & 0.78 & 0.3 & 1.09 \\
\hline T203 & 5 & -1.19 & 0.78 & 0.3 & 1.09 \\
\hline BY101 & 3 & -1.19 & 0.78 & 0.3 & 1.09 \\
\hline BY108 & 3 & -1.19 & 0.78 & 0.3 & 1.09 \\
\hline BY110 & 3 & -1.19 & 0.78 & 0.3 & 1.09 \\
\hline BY111 & 8 & -1.19 & 0.78 & 0.3 & 1.09 \\
\hline BY112 & 8 & -1.19 & 0.78 & 0.3 & 1.09 \\
\hline C108 & 8 & -1.19 & 0.78 & 0.3 & 1.09 \\
\hline C109 & 8 & -1.19 & 0.78 & 0.3 & 1.09 \\
\hline C111 & 8 & -1.19 & 0.78 & 0.3 & 1.09 \\
\hline C102 & 30 & -1.21 & 0.63 & 0.3 & 0.84 \\
\hline T102 & 19 & -1.22 & 0.78 & 0.3 & 1.07 \\
\hline T103 & 19 & -1.22 & 0.78 & 0.3 & 1.07 \\
\hline TY105 & 25 & -1.22 & 0.55 & 0.3 & 0.73 \\
\hline BX109 & 4 & -1.22 & 0.63 & 0.29 & 0.84 \\
\hline B105 & 2 & -1.22 & 0.77 & 0.29 & 1.04 \\
\hline & & & & & \\
\hline
\end{tabular}


Table 4.10. (contd)

\begin{tabular}{|c|c|c|c|c|c|}
\hline Tank & $\begin{array}{l}\text { SORWT } \\
\text { Number } \\
\end{array}$ & $\begin{array}{c}\text { Mean Log } \\
\text { TOC }\end{array}$ & $\begin{array}{c}\text { SD Log } \\
\text { TOC }\end{array}$ & $\begin{array}{c}\text { Median TOC } \\
\text { wet } \%\end{array}$ & $\begin{array}{l}95 \% \text { Confidence } \\
\text { Limit } \\
\end{array}$ \\
\hline TX113 & 2 & -1.22 & 0.77 & 0.29 & 1.04 \\
\hline TX117 & 2 & -1.22 & 0.77 & 0.29 & 1.04 \\
\hline TX102 & 1 & -1.23 & 0.49 & 0.29 & 0.65 \\
\hline B111 & 15 & -1.23 & 0.78 & 0.29 & 1.06 \\
\hline B112 & 15 & -1.23 & 0.78 & 0.29 & 1.06 \\
\hline $\mathrm{A} 102$ & 9 & -1.23 & 0.28 & 0.29 & 0.46 \\
\hline TX103 & 26 & -1.23 & 0.5 & 0.29 & 0.66 \\
\hline S104 & 6 & -1.24 & 0.64 & 0.29 & 0.83 \\
\hline TX112 & 2 & -1.25 & 0.63 & 0.29 & 0.81 \\
\hline B106 & 11 & -1.27 & 0.78 & 0.28 & 1.01 \\
\hline B107 & 12 & -1.27 & 0.78 & 0.28 & 1.01 \\
\hline B108 & 12 & -1.27 & 0.78 & 0.28 & 1.01 \\
\hline B109 & 12 & -1.27 & 0.78 & 0.28 & 1.01 \\
\hline BX108 & 4 & -1.27 & 0.78 & 0.28 & 1.01 \\
\hline T108 & 11 & -1.27 & 0.78 & 0.28 & 1.01 \\
\hline $\mathrm{C} 201$ & 13 & -1.28 & 0.64 & 0.28 & 0.8 \\
\hline SX104 & 1 & -1.28 & 0.49 & 0.28 & 0.62 \\
\hline BY103 & 3 & -1.29 & 0.63 & 0.27 & 0.78 \\
\hline $\mathrm{T} 112$ & 14 & -1.31 & 0.64 & 0.27 & 0.78 \\
\hline $\mathrm{T} 105$ & 17 & -1.31 & 0.78 & 0.27 & 0.97 \\
\hline T106 & 17 & -1.31 & 0.78 & 0.27 & 0.97 \\
\hline TY104 & 27 & -1.32 & 0.33 & 0.27 & 0.46 \\
\hline BY106 & 3 & -1.32 & 0.55 & 0.27 & 0.66 \\
\hline BY105 & 3 & -1.33 & 0.55 & 0.26 & 0.65 \\
\hline TX114 & 2 & -1.34 & 0.63 & 0.26 & 0.74 \\
\hline SX101 & 1 & -1.36 & 0.45 & 0.26 & 0.54 \\
\hline B202 & 5 & -1.44 & 0.55 & 0.24 & 0.59 \\
\hline $\mathrm{C} 106$ & 23 & -1.45 & 0.45 & 0.23 & 0.49 \\
\hline TX118* & 22 & -1.47 & 0.37 & 0.23 & 0.42 \\
\hline $\mathrm{C} 105$ & 30 & -1.5 & 0.55 & 0.22 & 0.55 \\
\hline BY102 & 21 & -1.51 & 0.55 & 0.22 & 0.55 \\
\hline B204 & 5 & -1.51 & 0.64 & 0.22 & 0.63 \\
\hline TY106 & 25. & -1.52 & 0.5 & 0.22 & 0.5 \\
\hline C107 & 30 & -1.54 & 0.63 & 0.21 & 0.6 \\
\hline
\end{tabular}


Table 4.10. (contd)

\begin{tabular}{||l|c|c|c|c|c||}
\hline Tank & $\begin{array}{c}\text { SORWT } \\
\text { Number }\end{array}$ & $\begin{array}{c}\text { Mean Log } \\
\text { TOC }\end{array}$ & $\begin{array}{c}\text { SD Log } \\
\text { TOC }\end{array}$ & $\begin{array}{c}\text { Median TOC } \\
\text { wet \% }\end{array}$ & $\begin{array}{c}\text { 95\% Confidence } \\
\text { Limit }\end{array}$ \\
\hline S109 & 1 & -1.58 & 0.49 & 0.21 & 0.46 \\
\hline TX116 & 2 & -1.61 & 0.63 & 0.2 & 0.57 \\
\hline BX107 & 11 & -1.63 & 0.55 & 0.2 & 0.49 \\
\hline BX110 & 24 & -1.66 & 0.5 & 0.19 & 0.43 \\
\hline T101 & 19 & -1.74 & 0.64 & 0.18 & 0.5 \\
\hline C110 & 11 & -1.76 & 0.64 & 0.17 & 0.49 \\
\hline TY102 & 2 & -1.77 & 0.55 & 0.17 & 0.42 \\
\hline B110 & 15 & -1.83 & 0.64 & 0.16 & 0.46 \\
\hline T107 & 8 & -1.85 & 0.55 & 0.16 & 0.39 \\
\hline TX115 & 7 & -1.96 & 0.55 & 0.14 & 0.35 \\
\hline TY101 & 30 & -2.16 & 0.55 & 0.12 & 0.28 \\
\hline TY103 & 27 & -2.3 & 0.42 & 0.1 & 0.2 \\
\hline U110 & 17 & -2.44 & 0.35 & 0.09 & 0.16 \\
\hline * Original watchlist tanks. & \\
\hline
\end{tabular}


Table 4.11. TOC Wet Units, Mean Estimate

\begin{tabular}{|c|c|c|c|c|c|}
\hline Tank & $\begin{array}{l}\text { SORWT } \\
\text { Number }\end{array}$ & $\begin{array}{l}\text { Mean Log } \\
\text { TOC }\end{array}$ & $\begin{array}{l}\text { SD Log } \\
\text { TOC }\end{array}$ & $\begin{array}{c}\text { Mean TOC } \\
\text { wet } \%\end{array}$ & $\begin{array}{l}95 \% \text { Confidence } \\
\text { Limit } \\
\end{array}$ \\
\hline SX106* & 1 & 0.08 & 0.45 & 2.01 & 4.2 \\
\hline A101 & 9 & 0.06 & 0.25 & 1.97 & 2.99 \\
\hline U106* & 7 & 0.01 & 0.63 & 1.86 & 5.29 \\
\hline $\mathrm{U} 105$ & 10 & -0.02 & 0.56 & 1.81 & 4.52 \\
\hline $\mathrm{AX} 102$ & 28 & -0.17 & 0.5 & 1.57 & 3.54 \\
\hline T104 & 30 & -0.17 & 0.49 & 1.56 & 3.49 \\
\hline SX103 & 1 & -0.2 & 0.62 & 1.52 & 4.23 \\
\hline $\mathrm{U} 103$ & 7 & -0.33 & 0.55 & 1.33 & 3.3 \\
\hline S102* & 1 & -0.34 & 0.54 & 1.32 & 3.22 \\
\hline AX103 & 28 & -0.38 & 0.45 & 1.27 & 2.67 \\
\hline AX101 & 9 & -0.4 & 0.42 & 1.24 & 2.46 \\
\hline $\mathrm{U} 111^{*}$ & 7 & -0.42 & 0.49 & 1.22 & 2.74 \\
\hline A103 & 9 & -0.5 & 0.35 & 1.13 & 2 \\
\hline BY104 & 3 & -0.62 & 0.55 & 1 & 2.47 \\
\hline$\$ 101$ & 1 & -0.93 & 0.75 & 0.95 & 3.28 \\
\hline S103 & 1 & -0.93 & 0.75 & 0.95 & 3.28 \\
\hline S105 & 1 & -0.93 & 0.75 & 0.95 & 3.28 \\
\hline S106 & 1 & -0.93 & 0.75 & 0.95 & 3.28 \\
\hline S108 & 1 & -0.93 & 0.75 & 0.95 & 3.28 \\
\hline $\mathrm{S} 112$ & 1 & -0.93 & 0.75 & 0.95 & 3.28 \\
\hline SX105 & 1 & -0.93 & 0.75 & 0.95 & 3.28 \\
\hline TX104 & 1 & -0.93 & 0.75 & 0.95 & 3.28 \\
\hline TX107 & 1 & -0.93 & 0.75 & 0.95 & 3.28 \\
\hline $\mathbf{S} 110$ & 16 & -0.69 & 0.64 & 0.93 & 2.66 \\
\hline TX105 & 1 & -0.69 & 0.62 & 0.93 & 2.58 \\
\hline $\mathrm{U} 102$ & 7 & -0.96 & 0.77 & 0.92 & 3.26 \\
\hline SX102 & 1 & -0.71 & 0.62 & 0.91 & 2.53 \\
\hline C103* & 23 & -0.72 & 0.33 & 0.91 & 1.57 \\
\hline U107* & 10 & -0.99 & 0.78 & 0.89 & 3.23 \\
\hline U108 & 10 & -0.99 & 0.78 & 0.89 & 3.23 \\
\hline U109 & 10 & -0.99 & 0.78 & 0.89 & 3.23 \\
\hline \$107 & 1 & -0.74 & 0.41 & 0.88 & 1.74 \\
\hline S111 & 1 & -0.81 & 0.39 & 0.82 & 1.56 \\
\hline SX110 & 16 & -1.08 & 0.78 & 0.82 & 2.96 \\
\hline
\end{tabular}


Table 4.11. (contd)

\begin{tabular}{|c|c|c|c|c|c|}
\hline Tank & $\begin{array}{c}\text { SORWT } \\
\text { Number } \\
\end{array}$ & $\begin{array}{c}\text { Mean Log } \\
\text { TOC }\end{array}$ & $\begin{array}{l}\text { SD Log } \\
\text { TOC }\end{array}$ & $\begin{array}{c}\text { Mean TOC } \\
\text { wet } \%\end{array}$ & $\begin{array}{l}95 \% \text { Confidence } \\
\text { Limit } \\
\end{array}$ \\
\hline SX111 & 16 & -1.08 & 0.78 & 0.82 & 2.96 \\
\hline SX114 & 16 & -1.08 & 0.78 & 0.82 & 2.96 \\
\hline A104 & 30 & -1.14 & 0.79 & 0.8 & 2.92 \\
\hline A105 & 30 & -1.14 & 0.79 & 0.8 & 2.92 \\
\hline AX104 & 30 & -1.14 & 0.79 & 0.8 & 2.92 \\
\hline B101 & 18 & -1.14 & 0.79 & 0.8 & 2.92 \\
\hline B102 & 18 & -1.14 & 0.79 & 0.8 & 2.92 \\
\hline B103* & 18 & -1.14 & 0.79 & 0.8 & 2.92 \\
\hline B104 & 30 & -1.14 & 0.79 & 0.8 & 2.92 \\
\hline SX113 & 29 & -1.14 & 0.79 & 0.8 & 2.92 \\
\hline TX101 & 30 & -1.14 & 0.79 & 0.8 & 2.92 \\
\hline $\mathrm{U} 104$ & 29 & -1.14 & 0.79 & 0.8 & 2.92 \\
\hline $\mathrm{U} 112$ & 30 & -1.14 & 0.79 & 0.8 & 2.92 \\
\hline U201 & 20 & -1.14 & 0.79 & 0.8 & 2.92 \\
\hline $\mathrm{U} 202$ & 20 & -1.14 & 0.79 & 0.8 & 2.92 \\
\hline $\mathrm{U} 203$ & 20 & -1.14 & 0.79 & 0.8 & 2.92 \\
\hline $\mathrm{U} 204$ & 30 & -1.14 & 0.79 & 0.8 & 2.92 \\
\hline BX101 & 4 & -1.11 . & 0.77 & 0.79 & 2.81 \\
\hline BX102 & 4 & -1.11 & 0.77 & 0.79 & 2.81 \\
\hline BX103 & 4 & -1.11 & 0.77 & 0.79 & 2.81 \\
\hline $\mathrm{C} 101$ & 4 & -1.11 & 0.77 & 0.79 & 2.81 \\
\hline BX112 & 12 & -0.86 & 0.56 & 0.78 & 1.95 \\
\hline C104 & 30 & -0.86 & 0.55 & 0.78 & 1.93 \\
\hline T109 & 26 & -1.14 & 0.79 & 0.77 & 2.81 \\
\hline C112 & 8 & -0.88 & 0.5 & 0.77 & 1.73 \\
\hline SX108 & 6 & -1.14 & 0.78 & 0.77 & 2.76 \\
\hline SX109 & 6 & -1.14 & 0.78 & 0.77 & 2.76 \\
\hline $\mathrm{SX} 112$ & 6 & -1.14 & 0.78 & 0.77 & 2.76 \\
\hline SX115 & 6 & -1.14 & 0.78 & 0.77 & 2.76 \\
\hline U101 & 6 & -1.14 & 0.78 & 0.77 & 2.76 \\
\hline $\mathrm{C} 202$ & 13 & -1.16 & 0.78 & 0.76 & 2.74 \\
\hline $\mathrm{C} 203$ & 13 & -1.16 & 0.78 & 0.76 & 2.74 \\
\hline C204 & 13 & -1.16 & 0.78 & 0.76 & 2.74 \\
\hline $\mathrm{T} 110$ & 14 & -1.16 & 0.78 & 0.75 & 2.73 \\
\hline
\end{tabular}


Table 4.11. (contd)

\begin{tabular}{|c|c|c|c|c|c|}
\hline Tank & $\begin{array}{l}\text { SORWT } \\
\text { Number }\end{array}$ & $\begin{array}{l}\text { Mean Log } \\
\text { TOC }\end{array}$ & $\begin{array}{l}\text { SD Log } \\
\text { TOC }\end{array}$ & $\begin{array}{c}\text { Mean TOC } \\
\text { wet } \%\end{array}$ & $\begin{array}{c}\text { 95\% Confidence } \\
\text { Limit } \\
\end{array}$ \\
\hline $\mathrm{T} 111$ & 14 & -1.16 & 0.78 & 0.75 & 2.73 \\
\hline TX106 & 1 & -0.9 & 0.62 & 0.75 & 2.09 \\
\hline B201 & 5 & -1.19 & 0.78 & 0.73 & 2.62 \\
\hline B203 & 5 & -1.19 & 0.78 & 0.73 & 2.62 \\
\hline $\mathrm{T} 201$ & 5 & -1.19 & 0.78 & 0.73 & 2.62 \\
\hline $\mathrm{T} 202$ & 5 & -1.19 & 0.78 & 0.73 & 2.62 \\
\hline T203 & 5 & -1.19 & 0.78 & 0.73 & 2.62 \\
\hline BY101 & 3 & -1.19 & 0.78 & 0.73 & 2.62 \\
\hline BY108 & 3 & -1.19 & 0.78 & 0.73 & 2.62 \\
\hline BY110 & 3 & -1.19 & 0.78 & 0.73 & 2.62 \\
\hline BY111 & 8 & -1.19 & 0.78 & 0.73 & 2.62 \\
\hline BY112 & 8 & -1.19 & 0.78 & 0.73 & 2.62 \\
\hline $\mathrm{C} 108$ & 8 & -1.19 & 0.78 & 0.73 & 2.62 \\
\hline C109 & 8 & -1.19 & 0.78 & 0.73 & 2.62 \\
\hline C111 & 8 & -1.19 & 0.78 & 0.73 & 2.62 \\
\hline BX105 & 4 & -0.93 & 0.45 & 0.73 & 1.53 \\
\hline $\mathrm{T} 204$ & 5 & -0.95 & 0.64 & 0.71 & 2.04 \\
\hline T102 & 19 & -1.22 & 0.78 & 0.71 & 2.58 \\
\hline T103 & 19 & -1.22 & 0.78 & 0.71 & 2.58 \\
\hline B105 & 2 & -1.22 & 0.77 & 0.71 & 2.49 \\
\hline TX113 & 2 & -1.22 & 0.77 & 0.71 & 2.49 \\
\hline TX117 & 2 & -1.22 & 0.77 & 0.71 & 2.49 \\
\hline TX108 & 22 & -0.97 & 0.64 & 0.7 & 2.01 \\
\hline B111 & 15 & -1.23 & 0.78 & 0.7 & 2.55 \\
\hline B112 & 15 & -1.23 & 0.78 & 0.7 & 2.55 \\
\hline TX109 & 2 & -0.98 & 0.63 & 0.7 & 1.97 \\
\hline BX104 & 4 & -0.98 & 0.39 & 0.69 & 1.32 \\
\hline B106 & 11 & -1.27 & 0.78 & 0.68 & 2.43 \\
\hline B107 & 12 & -1.27 & 0.78 & 0.68 & 2.43 \\
\hline B108 & 12 & -1.27 & 0.78 & 0.68 & 2.43 \\
\hline B109 & 12 & -1.27 & 0.78 & 0.68 & 2.43 \\
\hline BX108 & 4 & -1.27 & 0.78 & 0.68 & 2.43 \\
\hline T108 & 11 & -1.27 & 0.78 & 0.68 & 2.43 \\
\hline T105 & 17 & -1.31 & 0.78 & 0.65 & 2.33 \\
\hline
\end{tabular}


Table 4.11. (contd)

\begin{tabular}{|c|c|c|c|c|c|}
\hline Tank & $\begin{array}{l}\text { SORWT } \\
\text { Number } \\
\end{array}$ & $\begin{array}{c}\text { Mean Log } \\
\text { TOC }\end{array}$ & $\begin{array}{l}\text { SD Log } \\
\text { TOC }\end{array}$ & $\begin{array}{c}\begin{array}{c}\text { Mean TOC } \\
\text { wet } \%\end{array} \\
\end{array}$ & $\begin{array}{l}95 \% \text { Confidence } \\
\text { Limit }\end{array}$ \\
\hline T106 & 17 & -1.31 & 0.78 & 0.65 & 2.33 \\
\hline TX110 & 2 & -1.08 & 0.49 & 0.63 & 1.41 \\
\hline SX107 & 6 & -1.08 & 0.64 & 0.63 & 1.79 \\
\hline TX111 & 2 & -1.09 & 0.63 & 0.62 & 1.76 \\
\hline BX106 & 4 & -1.11 & 0.63 & 0.61 & 1.74 \\
\hline BX111 & 24 & -1.12 & 0.64 & 0.61 & 1.73 \\
\hline BY109 & 21 & -1.12 & 0.5 & 0.6 & 1.37 \\
\hline BY107 & 3 & -1.15 & 0.63 & 0.59 & 1.66 \\
\hline A106 & 30 & -1.18 & 0.39 & 0.57 & 1.08 \\
\hline $\mathrm{C} 102$ & 30 & -1.21 & 0.63 & 0.55 & 1.55 \\
\hline TY105 & 25 & -1.22 & 0.55 & 0.55 & 1.36 \\
\hline BX109 & 4 & -1.22 & 0.63 & 0.55 & 1.55 \\
\hline TX102 & 1 & -1.23 & 0.49 & 0.54 & 1.21 \\
\hline $\mathrm{A} 102$ & 9 & -1.23 & 0.28 & 0.54 & 0.85 \\
\hline TX103 & 26 & -1.23 & 0.5 & 0.54 & 1.22 \\
\hline S104 & 6 & -1.24 & 0.64 & 0.54 & 1.54 \\
\hline TX112 & 2 & -1.25 & 0.63 & 0.53 & 1.5 \\
\hline C201 & 13 & -1.28 & 0.64 & 0.52 & 1.48 \\
\hline SX104 & 1 & -1.28 & 0.49 & 0.51 & 1.15 \\
\hline BY103 & 3 & -1.29 & 0.63 & 0.51 & 1.44 \\
\hline T112 & 14 & -1.31 & 0.64 & 0.5 & 1.44 \\
\hline TY104 & 27 & -1.32 & 0.33 & 0.5 & 0.86 \\
\hline BY106 & 3 & -1.32 & 0.55 & 0.5 & 1.23 \\
\hline BY105 & 3 & -1.33 & 0.55 & 0.49 & 1.21 \\
\hline TX114 & 2 & -1.34 & 0.63 & 0.49 & 1.37 \\
\hline SX101 & 1 & -1.36 & 0.45 & 0.48 & 0.99 \\
\hline B202 & 5 & -1.44 & 0.55 & 0.44 & 1.09 \\
\hline $\mathrm{C} 106$ & 23 & -1.45 & 0.45 & 0.43 & 0.91 \\
\hline TX118* & 22 & -1.47 & 0.37 & 0.42 & 0.78 \\
\hline C105 & 30 & -1.5 & 0.55 & 0.41 & 1.02 \\
\hline BY102 & 21 & -1.51 & 0.55 & 0.41 & 1.02 \\
\hline B204 & 5 & -1.51 & 0.64 & 0.41 & 1.16 \\
\hline TY106 & 25 & -1.52 & 0.5 & 0.41 & 0.92 \\
\hline $\mathrm{C} 107$ & 30 & -1.54 & 0.63 & 0.4 & 1.11 \\
\hline
\end{tabular}


Table 4.11. (contd)

\begin{tabular}{||l|c|c|c|c|c||}
\hline \multicolumn{1}{|c|}{ Tank } & $\begin{array}{c}\text { SORWT } \\
\text { Number }\end{array}$ & $\begin{array}{c}\text { Mean Log } \\
\text { TOC }\end{array}$ & $\begin{array}{c}\text { SD Log } \\
\text { TOC }\end{array}$ & $\begin{array}{c}\text { Mean TOC } \\
\text { wet \% }\end{array}$ & $\begin{array}{c}\text { 95\% Confidence } \\
\text { Limit }\end{array}$ \\
\hline S109 & 1 & -1.58 & 0.49 & 0.38 & 0.86 \\
\hline TX116 & 2 & -1.61 & 0.63 & 0.37 & 1.05 \\
\hline BX107 & 11 & -1.63 & 0.55 & 0.36 & 0.91 \\
\hline BX110 & 24 & -1.66 & 0.5 & 0.35 & 0.79 \\
\hline T101 & 19 & -1.74 & 0.64 & 0.33 & 0.93 \\
\hline C110 & 11 & -1.76 & 0.64 & 0.32 & 0.91 \\
\hline TY102 & 2 & -1.77 & 0.55 & 0.32 & 0.78 \\
\hline B110 & 15 & -1.83 & 0.64 & 0.3 & 0.86 \\
\hline T107 & 8 & -1.85 & 0.55 & 0.29 & 0.72 \\
\hline TX115 & 7 & -1.96 & 0.55 & 0.26 & 0.65 \\
\hline TY101 & 30 & -2.16 & 0.55 & 0.21 & 0.52 \\
\hline TY103 & 27 & -2.3 & 0.42 & 0.19 & 0.37 \\
\hline U110 & 17 & -2.44 & 0.35 & 0.16 & 0.29 \\
\hline$*$ Original watchlist tanks. & & & \\
\hline
\end{tabular}


Table 4.12. TOC Dry Units, Median Estimate

\begin{tabular}{|c|c|c|c|c|c|}
\hline Tank & $\begin{array}{l}\text { SORWT } \\
\text { Number }\end{array}$ & $\begin{array}{l}\text { Mean Log } \\
\text { TOC }\end{array}$ & $\begin{array}{l}\text { SD Log } \\
\text { TOC }\end{array}$ & $\begin{array}{l}\text { Median } \\
\text { TOC dry \% }\end{array}$ & $\begin{array}{l}\text { 95\% Confidence } \\
\text { Limit }\end{array}$ \\
\hline C103* & 23 & 1.35 & 0.33 & 3.84 & 6.66 \\
\hline T104 & 30 & 0.75 & 0.49 & 2.11 & 4.74 \\
\hline SX106* & 1 & 0.72 & 0.45 & 2.06 & 4.3 \\
\hline U106* & 7 & 0.63 & 0.63 & 1.87 & 5.32 \\
\hline U105 & 10 & 0.61 & 0.56 & 1.84 & 4.59 \\
\hline A101 & 9 & 0.57 & 0.25 & 1.77 & 2.69 \\
\hline $\mathrm{AX} 102$ & 28 & 0.49 & 0.5 & 1.63 & 3.69 \\
\hline A103 & 9 & 0.43 & 0.35 & 1.54 & 2.74 \\
\hline SX103 & 1 & 0.37 & 0.62 & 1.45 & 4.05 \\
\hline U103 & 7 & 0.23 & 0.55 & 1.26 & 3.13 \\
\hline $\mathrm{T} 102$ & 19 & 0.22 & 0.78 & 1.25 & 4.52 \\
\hline BX106 & 4 & 0.2 & 0.63 & 1.23 & 3.48 \\
\hline U203 & 20 & 0.18 & 0.79 & 1.2 & 4.39 \\
\hline U204 & 30 & 0.18 & 0.79 & 1.2 & 4.39 \\
\hline S102* & 1 & 0.17 & 0.54 & 1.19 & 2.91 \\
\hline AX103 & 28 & 0.14 & 0.45 & 1.15 & 2.42 \\
\hline $\mathrm{U} 111^{*}$ & 7 & 0.12 & 0.49 & 1.13 & 2.54 \\
\hline AX101 & 9 & 0.11 & 0.42 & 1.12 & 2.21 \\
\hline S107 & 1 & 0.1 & 0.41 & 1.1 & 2.18 \\
\hline BX112 & 12 & 0.06 & 0.56 & 1.06 & 2.66 \\
\hline BX105 & 4 & 0.06 & 0.45 & 1.06 & 2.22 \\
\hline C104 & 30 & 0.05 & 0.55 & 1.06 & 2.6 \\
\hline C112 & 8 & 0.03 & 0.5 & 1.03 & 2.34 \\
\hline U201 & 20 & 0 & 0.79 & 1 & 3.66 \\
\hline $\mathrm{U} 202$ & 20 & 0 & 0.79 & 1 & 3.66 \\
\hline T204 & 5 & -0.04 & 0.64 & 0.96 & 2.75 \\
\hline BX104 & 4 & -0.04 & 0.39 & 0.96 & 1.83 \\
\hline $\mathbf{S} 110$ & 16 & -0.06 & 0.64 & 0.94 & 2.7 \\
\hline BY104 & 3 & -0.07 & 0.55 & 0.93 & 2.3 \\
\hline U101 & 6 & -0.1 & 0.78 & 0.91 & 3.27 \\
\hline SX102 & 1 & -0.13 & 0.62 & 0.88 & 2.46 \\
\hline BX103 & 4 & -0.13 & 0.77 & 0.88 & 3.12 \\
\hline U112 & 30 & -0.14 & 0.79 & 0.87 & 3.18 \\
\hline T103 & 19 & -0.14 & 0.78 & 0.87 & 3.15 \\
\hline
\end{tabular}


Table 4.12. (contd)

\begin{tabular}{||l|c|c|c|c|c||}
\hline Tank & $\begin{array}{c}\text { SORWT } \\
\text { Number }\end{array}$ & $\begin{array}{c}\text { Mean Log } \\
\text { TOC }\end{array}$ & $\begin{array}{c}\text { SD Log } \\
\text { TOC }\end{array}$ & $\begin{array}{c}\text { Median } \\
\text { TOC dry \% }\end{array}$ & $\begin{array}{c}\text { 95\% Confidence } \\
\text { Limit }\end{array}$ \\
\hline SX110 & 16 & -0.16 & 0.78 & 0.85 & 3.09 \\
\hline SX111 & 16 & -0.16 & 0.78 & 0.85 & 3.09 \\
\hline SX114 & 16 & -0.16 & 0.78 & 0.85 & 3.09 \\
\hline BX101 & 4 & -0.17 & 0.77 & 0.85 & 3 \\
\hline SX107 & 6 & -0.17 & 0.64 & 0.85 & 2.42 \\
\hline S101 & 1 & -0.17 & 0.75 & 0.84 & 2.91 \\
\hline TX105* & 1 & -0.18 & 0.62 & 0.83 & 2.33 \\
\hline TX101 & 30 & -0.19 & 0.79 & 0.83 & 3.03 \\
\hline BX102 & 4 & -0.19 & 0.77 & 0.83 & 2.93 \\
\hline C101 & 4 & -0.19 & 0.77 & 0.83 & 2.93 \\
\hline S111 & 1 & -0.2 & 0.39 & 0.82 & 1.55 \\
\hline C109 & 8 & -0.21 & 0.78 & 0.81 & 2.9 \\
\hline B112 & 15 & -0.22 & 0.78 & 0.8 & 2.92 \\
\hline A104 & 30 & -0.22 & 0.79 & 0.8 & 2.92 \\
\hline A105 & 30 & -0.22 & 0.79 & 0.8 & 2.92 \\
\hline AX104 & 30 & -0.22 & 0.79 & 0.8 & 2.92 \\
\hline B101 & 18 & -0.22 & 0.79 & 0.8 & 2.92 \\
\hline B103* & 18 & -0.22 & 0.79 & 0.8 & 2.92 \\
\hline SX113 & 29 & -0.22 & 0.79 & 0.8 & 2.92 \\
\hline T109 & 26 & -0.22 & 0.79 & 0.8 & 2.92 \\
\hline U104 & 29 & -0.22 & 0.79 & 0.8 & 2.92 \\
\hline SX108 & 6 & -0.23 & 0.78 & 0.8 & 2.88 \\
\hline SX109 & 6 & -0.23 & 0.78 & 0.8 & 2.88 \\
\hline SX112 & 6 & -0.23 & 0.78 & 0.8 & 2.88 \\
\hline SX115 & 6 & -0.23 & 0.78 & 0.8 & 2.88 \\
\hline T110 & 14 & -0.24 & 0.78 & 0.79 & 2.87 \\
\hline B201 & 5 & -0.24 & 0.78 & 0.79 & 2.83 \\
\hline T201 & 5 & -0.24 & 0.78 & 0.79 & 2.83 \\
\hline T111 & 14 & -0.24 & 0.78 & 0.79 & 2.86 \\
\hline C202 & 13 & -0.24 & 0.78 & 0.79 & 2.85 \\
\hline C203 & 13 & -0.24 & 0.78 & 0.79 & 2.85 \\
\hline C204 & 13 & -0.24 & 0.78 & 0.79 & 2.85 \\
\hline B102 & 18 & -0.25 & 0.79 & 0.78 & 2.84 \\
\hline B203 & 5 & -0.25 & 0.78 & 0.78 & 2.78 \\
\hline & & & & & \\
\hline
\end{tabular}


Table 4.12. (contd)

\begin{tabular}{|c|c|c|c|c|c|}
\hline Tank & $\begin{array}{l}\text { SORWT } \\
\text { Number } \\
\end{array}$ & $\begin{array}{l}\text { Mean Log } \\
\text { TOC }\end{array}$ & $\begin{array}{l}\text { SD Log } \\
\text { TOC }\end{array}$ & $\begin{array}{c}\text { Median } \\
\text { TOC dry \% }\end{array}$ & $\begin{array}{c}\text { 95\% Confidence } \\
\text { Limit } \\
\end{array}$ \\
\hline A106 & 30 & -0.26 & 0.39 & 0.77 & 1.46 \\
\hline $\mathrm{T} 202$ & 5 & -0.27 & 0.78 & 0.76 & 2.73 \\
\hline $\mathrm{T} 203$ & 5 & -0.27 & 0.78 & 0.76 & 2.73 \\
\hline $\mathrm{C} 108$ & 8 & -0.27 & 0.78 & 0.76 & 2.73 \\
\hline $\mathrm{C} 111$ & 8 & -0.27 & 0.78 & 0.76 & 2.73 \\
\hline $\mathrm{T} 112$ & 14 & -0.28 & 0.64 & 0.76 & 2.17 \\
\hline T106 & 17 & -0.29 & 0.78 & 0.74 & 2.68 \\
\hline $\mathrm{C} 102$ & 30 & -0.3 & 0.63 & 0.74 & 2.09 \\
\hline TY105 & 25 & -0.3 & 0.55 & 0.74 & 1.84 \\
\hline BX109 & 4 & -0.31 & 0.63 & 0.74 & 2.09 \\
\hline B104 & 30 & -0.31 & 0.79 & 0.74 & 2.68 \\
\hline B111 & 15 & -0.31 & 0.78 & 0.73 & 2.66 \\
\hline TX103 & 26 & -0.32 & 0.5 & 0.73 & 1.65 \\
\hline S104 & 6 & -0.32 & 0.64 & 0.73 & 2.08 \\
\hline S103 & 1 & -0.33 & 0.75 & 0.72 & 2.48 \\
\hline TY104 & 27 & -0.33 & 0.33 & 0.72 & 1.24 \\
\hline B106 & 11 & -0.34 & 0.78 & 0.71 & 2.55 \\
\hline B107 & 12 & -0.35 & 0.78 & 0.71 & 2.55 \\
\hline B108 & 12 & -0.35 & 0.78 & 0.7 & 2.53 \\
\hline B109 & 12 & -0.35 & 0.78 & 0.7 & 2.53 \\
\hline BX108 & 4 & -0.35 & 0.78 & 0.7 & 2.53 \\
\hline T108 & 11 & -0.35 & 0.78 & 0.7 & 2.53 \\
\hline $\mathrm{U} 102$ & 7 & -0.36 & 0.77 & 0.7 & 2.48 \\
\hline C201 & 13 & -0.36 & 0.64 & 0.7 & 2 \\
\hline SX105 & 1 & -0.38 & 0.75 & 0.68 & 2.36 \\
\hline $\mathrm{U} 107 *$ & 10 & -0.38 & 0.78 & 0.68 & 2.46 \\
\hline C106 & 23 & -0.39 & 0.45 & 0.68 & 1.43 \\
\hline TX107 & 1 & -0.39 & 0.75 & 0.68 & 2.34 \\
\hline TX106 & 1 & -0.39 & 0.62 & 0.68 & 1.88 \\
\hline $\mathrm{T} 105$ & 17 & -0.39 & 0.78 & 0.67 & 2.43 \\
\hline S106 & 1 & -0.4 & 0.75 & 0.67 & 2.32 \\
\hline U109 & 10 & -0.4 & 0.78 & 0.67 & 2.43 \\
\hline TX104 & 1 & -0.4 & 0.75 & 0.67 & 2.31 \\
\hline U108 & 10 & -0.4 & 0.78 & 0.67 & 2.42 \\
\hline
\end{tabular}


Table 4.12. (contd)

\begin{tabular}{|c|c|c|c|c|c|}
\hline Tank & $\begin{array}{l}\text { SORWT } \\
\text { Number }\end{array}$ & $\begin{array}{l}\text { Mean Log } \\
\text { TOC }\end{array}$ & $\begin{array}{l}\text { SD Log } \\
\text { TOC }\end{array}$ & $\begin{array}{l}\text { Median } \\
\text { TOC dry \% }\end{array}$ & $\begin{array}{l}95 \% \text { Confidence } \\
\text { Limit }\end{array}$ \\
\hline BX111 & 24 & -0.4 & 0.64 & 0.67 & 1.91 \\
\hline S112 & 1 & -0.41 & 0.75 & 0.66 & 2.28 \\
\hline S108 & 1 & -0.41 & 0.75 & 0.66 & 2.28 \\
\hline S105 & 1 & -0.41 & 0.75 & 0.66 & 2.28 \\
\hline BY108 & 3 & -0.43 & 0.78 & 0.65 & 2.34 \\
\hline TX108 & 22 & -0.46 & 0.64 & 0.63 & 1.81 \\
\hline A102 & 9 & -0.47 & 0.28 & 0.63 & 0.99 \\
\hline TX109 & 2 & -0.47 & 0.63 & 0.63 & 1.77 \\
\hline B202 & 5 & -0.52 & 0.55 & 0.59 & 1.47 \\
\hline BY109 & 21 & -0.54 & 0.5 & 0.58 & 1.32 \\
\hline BY107 & 3 & -0.56 & 0.63 & 0.57 & 1.62 \\
\hline TX110 & 2 & -0.57 & 0.49 & 0.56 & 1.27 \\
\hline B204 & 5 & -0.58 & 0.64 & 0.56 & 1.6 \\
\hline TX111 & 2 & -0.58 & 0.63 & 0.56 & 1.58 \\
\hline BY101 & 3 & -0.58 & 0.78 & 0.56 & 2 \\
\hline C105 & 30 & -0.58 & 0.55 & 0.56 & 1.37 \\
\hline BY110 & 3 & -0.59 & 0.78 & 0.55 & 1.99 \\
\hline TY106 & 25 & -0.6 & 0.5 & 0.55 & 1.24 \\
\hline C107. & 30 & -0.63 & 0.63 & 0.53 & 1.5 \\
\hline BY111 & 8 & -0.66 & 0.78 & 0.51 & 1.84 \\
\hline B105 & 2 & -0.67 & 0.77 & 0.51 & 1.81 \\
\hline BY112 & 8 & -0.67 & 0.78 & 0.51 & 1.83 \\
\hline SX104 & 1 & -0.69 & 0.49 & 0.5 & 1.12 \\
\hline BX107 & 11 & -0.71 & 0.55 & 0.49 & 1.23 \\
\hline TX113 & 2 & -0.71 & 0.77 & 0.49 & 1.73 \\
\hline TX117 & 2 & -0.71 & 0.77 & 0.49 & 1.73 \\
\hline TX102 & 1 & -0.72 & 0.49 & 0.49 & 1.09 \\
\hline TX112 & 2 & -0.74 & 0.63 & 0.48 & 1.35 \\
\hline BY106 & 3 & -0.76 & 0.55 & 0.47 & 1.16 \\
\hline SX101 & 1 & -0.76 & 0.45 & 0.47 & 0.98 \\
\hline BX110 & 24 & -0.76 & 0.5 & 0.47 & 1.05 \\
\hline BY103 & 3 & -0.78 & 0.63 & 0.46 & 1.3 \\
\hline BY105 & 3 & -0.79 & 0.55 & 0.45 & 1.12 \\
\hline T101 & 19 & -0.81 & 0.64 & 0.44 & 1.28 \\
\hline
\end{tabular}


Table 4.12. (contd)

\begin{tabular}{||l|c|c|c|c|c||}
\hline Tank & $\begin{array}{c}\text { SORWT } \\
\text { Number }\end{array}$ & $\begin{array}{c}\text { Mean Log } \\
\text { TOC }\end{array}$ & $\begin{array}{c}\text { SD Log } \\
\text { TOC }\end{array}$ & $\begin{array}{c}\text { Median } \\
\text { TOC dry \% }\end{array}$ & $\begin{array}{c}\text { 95\% Confidence } \\
\text { Limit }\end{array}$ \\
\hline TX114 & 2 & -0.83 & 0.63 & 0.44 & 1.24 \\
\hline C110 & 11 & -0.84 & 0.64 & 0.43 & 1.23 \\
\hline T107 & 8 & -0.88 & 0.55 & 0.41 & 1.03 \\
\hline B110 & 15 & -0.91 & 0.64 & 0.4 & 1.16 \\
\hline TX118* & 22 & -0.96 & 0.37 & 0.38 & 0.7 \\
\hline BY102 & 21 & -1 & 0.55 & 0.37 & 0.92 \\
\hline S109 & 1 & -1.06 & 0.49 & 0.35 & 0.78 \\
\hline TX116 & 2 & -1.09 & 0.63 & 0.33 & 0.95 \\
\hline TY101 & 30 & -1.25 & 0.55 & 0.29 & 0.71 \\
\hline TY102 & 2 & -1.26 & 0.55 & 0.28 & 0.7 \\
\hline TY103 & 27 & -1.38 & 0.42 & 0.25 & 0.5 \\
\hline TX115 & 7 & -1.44 & 0.55 & 0.24 & 0.58 \\
\hline U110 & 17 & -1.52 & 0.35 & 0.22 & 0.39 \\
\hline$*$ Original watchlist tanks. & & & \\
\hline
\end{tabular}


Table 4.13. TOC Dry Units, Mean Estimate

\begin{tabular}{||l|c|c|c|c|c||}
\hline Tank & $\begin{array}{c}\text { SORWT } \\
\text { Number }\end{array}$ & $\begin{array}{c}\text { Mean Log } \\
\text { TOC }\end{array}$ & $\begin{array}{c}\text { SD Log } \\
\text { TOC }\end{array}$ & $\begin{array}{c}\text { Mean TOC } \\
\text { dry \% }\end{array}$ & $\begin{array}{c}95 \% \text { Confidence } \\
\text { Limit }\end{array}$ \\
\hline C103* & 23 & 1.35 & 0.33 & 7.12 & 12.33 \\
\hline T104 & 30 & 0.75 & 0.49 & 3.91 & 8.78 \\
\hline SX106* & 1 & 0.72 & 0.45 & 3.82 & 7.96 \\
\hline U106* & 7 & 0.63 & 0.63 & 3.47 & 9.84 \\
\hline U105 & 10 & 0.61 & 0.56 & 3.41 & 8.5 \\
\hline A101 & 9 & 0.57 & 0.25 & 3.28 & 4.99 \\
\hline AX102 & 28 & 0.49 & 0.5 & 3.03 & 6.83 \\
\hline U203 & 20 & 0.18 & 0.79 & 3.01 & 10.96 \\
\hline U204 & 30 & 0.18 & 0.79 & 3.01 & 10.96 \\
\hline T102 & 19 & 0.22 & 0.78 & 2.99 & 10.85 \\
\hline A103 & 9 & 0.43 & 0.35 & 2.85 & 5.06 \\
\hline SX103 & 1 & 0.37 & 0.62 & 2.69 & 7.5 \\
\hline U201 & 20 & 0 & 0.79 & 2.5 & 9.13 \\
\hline U202 & 20 & 0 & 0.79 & 2.5 & 9.13 \\
\hline U103 & 7 & 0.23 & 0.55 & 2.34 & 5.8 \\
\hline BX106 & 4 & 0.2 & 0.63 & 2.27 & 6.44 \\
\hline S102* & 1 & 0.17 & 0.54 & 2.2 & 5.39 \\
\hline U112 & 30 & -0.14 & 0.79 & 2.18 & 7.96 \\
\hline U101 & 6 & -0.1 & 0.78 & 2.17 & 7.85 \\
\hline AX103 & 28 & 0.14 & 0.45 & 2.13 & 4.47 \\
\hline BX103 & 4 & -0.13 & 0.77 & 2.11 & 7.48 \\
\hline U111* & 7 & 0.12 & 0.49 & 2.09 & 4.7 \\
\hline T103 & 19 & -0.14 & 0.78 & 2.08 & 7.56 \\
\hline TX101 & 30 & -0.19 & 0.79 & 2.08 & 7.57 \\
\hline AX101 & 9 & 0.11 & 0.42 & 2.07 & 4.1 \\
\hline S107 & 1 & 0.1 & 0.41 & 2.04 & 4.04 \\
\hline SX110 & 16 & -0.16 & 0.78 & 2.04 & 7.41 \\
\hline SX111 & 16 & -0.16 & 0.78 & 2.04 & 7.41 \\
\hline SX114 & 16 & -0.16 & 0.78 & 2.04 & 7.41 \\
\hline BX101 & 4 & -0.17 & 0.77 & 2.03 & 7.2 \\
\hline S101 & 1 & -0.17 & 0.75 & 2.03 & 6.99 \\
\hline A104 & 30 & -0.22 & 0.79 & 2 & 7.31 \\
\hline A105 & 30 & -0.22 & 0.79 & 2 & 7.31 \\
\hline AX104 & 30 & -0.22 & 0.79 & 2 & 7.31 \\
\hline & & & & & \\
\hline
\end{tabular}


Table 4.13. (contd)

\begin{tabular}{||l|c|c|c|c|c||}
\hline Tank & $\begin{array}{c}\text { SORWT } \\
\text { Number }\end{array}$ & $\begin{array}{c}\text { Mean Log } \\
\text { TOC }\end{array}$ & $\begin{array}{c}\text { SD Log } \\
\text { TOC }\end{array}$ & $\begin{array}{c}\text { Mean TOC } \\
\text { dry \% }\end{array}$ & $\begin{array}{c}\text { 95\% Confidence } \\
\text { Limit }\end{array}$ \\
\hline B101 & 18 & -0.22 & 0.79 & 2 & 7.31 \\
\hline B103* & 18 & -0.22 & 0.79 & 2 & 7.31 \\
\hline SX113 & 29 & -0.22 & 0.79 & 2 & 7.31 \\
\hline U104 & 29 & -0.22 & 0.79 & 2 & 7.31 \\
\hline BX102 & 4 & -0.19 & 0.77 & 1.98 & 7.03 \\
\hline C101 & 4 & -0.19 & 0.77 & 1.98 & 7.03 \\
\hline BX112 & 12 & 0.06 & 0.56 & 1.97 & 4.92 \\
\hline BX105 & 4 & 0.06 & 0.45 & 1.96 & 4.11 \\
\hline C104 & 30 & 0.05 & 0.55 & 1.96 & 4.81 \\
\hline B102 & 18 & -0.25 & 0.79 & 1.94 & 7.08 \\
\hline C109 & 8 & -0.21 & 0.78 & 1.94 & 6.96 \\
\hline B112 & 15 & -0.22 & 0.78 & 1.93 & 7 \\
\hline T109 & 26 & -0.22 & 0.79 & 1.92 & 7.02 \\
\hline C112 & 8 & 0.03 & 0.5 & 1.92 & 4.33 \\
\hline SX108 & 6 & -0.23 & 0.78 & 1.91 & 6.91 \\
\hline SX109 & 6 & -0.23 & 0.78 & 1.91 & 6.91 \\
\hline SX112 & 6 & -0.23 & 0.78 & 1.91 & 6.91 \\
\hline SX115 & 6 & -0.23 & 0.78 & 1.91 & 6.91 \\
\hline T110 & 14 & -0.24 & 0.78 & 1.9 & 6.88 \\
\hline B201 & 5 & -0.24 & 0.78 & 1.89 & 6.78 \\
\hline T201 & 5 & -0.24 & 0.78 & 1.89 & 6.78 \\
\hline T111 & 14 & -0.24 & 0.78 & 1.89 & 6.85 \\
\hline C202 & 13 & -0.24 & 0.78 & 1.89 & 6.85 \\
\hline C203 & 13 & -0.24 & 0.78 & 1.89 & 6.85 \\
\hline C204 & 13 & -0.24 & 0.78 & 1.89 & 6.85 \\
\hline B203 & 5 & -0.25 & 0.78 & 1.86 & 6.68 \\
\hline B104 & 30 & -0.31 & 0.79 & 1.84 & 6.7 \\
\hline T202 & 5 & -0.27 & 0.78 & 1.83 & 6.55 \\
\hline T203 & 5 & -0.27 & 0.78 & 1.83 & 6.55 \\
\hline C108 & 8 & -0.27 & 0.78 & 1.82 & 6.54 \\
\hline C111 & 8 & -0.27 & 0.78 & 1.82 & 6.54 \\
\hline T106 & 17 & -0.29 & 0.78 & 1.79 & 6.44 \\
\hline T204 & 5 & -0.04 & 0.64 & 1.78 & 5.09 \\
\hline BX104 & 4 & -0.04 & 0.39 & 1.78 & 3.39 \\
\hline & & & & & \\
\hline
\end{tabular}


Table 4.13. (contd)

\begin{tabular}{|c|c|c|c|c|c|}
\hline Tank & $\begin{array}{l}\text { SORWT } \\
\text { Number }\end{array}$ & $\begin{array}{l}\text { Mean Log } \\
\text { TOC }\end{array}$ & $\begin{array}{l}\text { SD Log } \\
\text { TOC }\end{array}$ & $\begin{array}{c}\text { Mean TOC } \\
\text { dry } \%\end{array}$ & $\begin{array}{l}\text { 95\% Confidence } \\
\text { Limit } \\
\end{array}$ \\
\hline B111 & 15 & -0.31 & 0.78 & 1.76 & 6.39 \\
\hline$\$ 110$ & 16 & -0.06 & 0.64 & 1.74 & 5 \\
\hline S103 & 1 & -0.33 & 0.75 & 1.73 & 5.95 \\
\hline BY104 & 3 & -0.07 & 0.55 & 1.72 & 4.26 \\
\hline B106 & 11 & -0.34 & 0.78 & 1.7 & 6.13 \\
\hline B107 & 12 & -0.35 & 0.78 & 1.7 & 6.12 \\
\hline B108 & 12 & -0.35 & 0.78 & 1.69 & 6.08 \\
\hline B109 & 12 & -0.35 & 0.78 & 1.69 & 6.08 \\
\hline BX108 & 4 & -0.35 & 0.78 & 1.69 & 6.08 \\
\hline T108 & 11 & -0.35 & 0.78 & 1.69 & 6.08 \\
\hline U102 & 7 & -0.36 & 0.77 & 1.68 & 5.96 \\
\hline SX105 & .1 & -0.38 & 0.75 & 1.64 & 5.66 \\
\hline $\mathrm{U} 107^{*}$ & 10 & -0.38 & 0.78 & 1.63 & 5.91 \\
\hline SX102 & 1 & -0.13 & 0.62 & 1.63 & 4.55 \\
\hline TX107 & 1 & -0.39 & 0.75 & 1.63 & 5.62 \\
\hline T105 & 17 & -0.39 & 0.78 & 1.62 & 5.82 \\
\hline S106 & 1 & -0.4 & 0.75 & 1.62 & 5.57 \\
\hline U109 & 10 & -0.4 & 0.78 & 1.61 & 5.83 \\
\hline TX104 & 1 & -0.4 & 0.75 & 1.61 & 5.55 \\
\hline $\mathrm{U} 108$ & 10 & -0.4 & 0.78 & 1.6 & 5.81 \\
\hline S112 & 1 & -0.41 & 0.75 & 1.59 & 5.48 \\
\hline S108 & 1. & -0.41 & 0.75 & 1.59 & 5.47 \\
\hline S105 & 1 & -0.41 & 0.75 & 1.59 & 5.47 \\
\hline BY108 & 3 & -0.43 & 0.78 & 1.57 & 5.63 \\
\hline SX107 & 6 & -0.17 & 0.64 & 1.56 & 4.48 \\
\hline TX105* & 1 & -0.18 & 0.62 & 1.54 & 4.31 \\
\hline S111 & 1 & -0.2 & 0.39 & 1.52 & 2.87 \\
\hline A106 & 30 & -0.26 & 0.39 & 1.43 & 2.71 \\
\hline $\mathrm{T} 112$ & 14 & -0.28 & 0.64 & 1.4 & 4.02 \\
\hline $\mathrm{C} 102$ & 30 & -0.3 & 0.63 & 1.38 & 3.87 \\
\hline TY105 & 25 & -0.3 & 0.55 & 1.37 & 3.4 \\
\hline BX109 & 4 & -0.31 & 0.63 & 1.36 & 3.87 \\
\hline TX103 & 26 & -0.32 & 0.5 & 1.35 & 3.06 \\
\hline S104 & 6 & -0.32 & 0.64 & 1.35 & 3.86 \\
\hline
\end{tabular}


Table 4.13. (contd)

\begin{tabular}{|c|c|c|c|c|c|}
\hline Tank & $\begin{array}{c}\text { SORWT } \\
\text { Number } \\
\end{array}$ & $\begin{array}{c}\text { Mean Log } \\
\text { TOC }\end{array}$ & $\begin{array}{c}\text { SD Log } \\
\text { TOC }\end{array}$ & $\begin{array}{c}\text { Mean TOC } \\
\text { dry } \%\end{array}$ & $\begin{array}{l}\text { 95\% Confidence } \\
\text { Limit } \\
\end{array}$ \\
\hline BY101 & 3 & -0.58 & 0.78 & 1.34 & 4.81 \\
\hline BY110 & 3 & -0.59 & 0.78 & 1.33 & 4.77 \\
\hline TY104 & 27 & -0.33 & 0.33 & 1.33 & 2.3 \\
\hline C201 & 13 & -0.36 & 0.64 & 1.29 & 3.7 \\
\hline C106 & 23 & -0.39 & 0.45 & 1.26 & 2.64 \\
\hline TX106 & 1 & -0.39 & 0.62 & 1.25 & 3.49 \\
\hline BX111 & 24 & -0.4 & 0.64 & 1.23 & 3.53 \\
\hline BY111 & 8 & -0.66 & 0.78 & 1.23 & 4.43 \\
\hline B105 & 2 & -0.67 & 0.77 & 1.23 & 4.34 \\
\hline BY112 & 8 & -0.67 & 0.78 & 1.22 & 4.39 \\
\hline TX113 & 2 & -0.71 & 0.77 & 1.18 & 4.15 \\
\hline TX117 & 2 & -0.71 & 0.77 & 1.18 & 4.15 \\
\hline TX108 & 22 & -0.46 & 0.64 & 1.17 & 3.35 \\
\hline $\mathrm{A} 102$ & 9 & -0.47 & 0.28 & 1.16 & 1.83 \\
\hline TX109 & 2 & -0.47 & 0.63 & 1.16 & 3.28 \\
\hline $\mathrm{B} 202$ & 5 & -0.52 & 0.55 & 1.1 & 2.73 \\
\hline BY109 & 21 & -0.54 & 0.5 & 1.08 & 2.44 \\
\hline BY107 & 3 & -0.56 & 0.63 & 1.06 & 3 \\
\hline TX110 & 2 & -0.57 & 0.49 & 1.04 & 2.35 \\
\hline B204 & 5 & -0.58 & 0.64 & 1.04 & 2.97 \\
\hline TX111 & 2 & -0.58 & 0.63 & 1.04 & 2.93 \\
\hline C105 & 30 & -0.58 & 0.55 & 1.03 & 2.54 \\
\hline TY106 & 25 & -0.6 & 0.5 & 1.01 & 2.29 \\
\hline C107 & 30 & -0.63 & 0.63 & 0.99 & 2.78 \\
\hline SX104 & 1 & -0.69 & 0.49 & 0.93 & 2.07 \\
\hline BX107 & 11 & -0.71 & 0.55 & 0.91 & 2.27 \\
\hline TX102 & 1 & -0.72 & 0.49 & 0.9 & 2.02 \\
\hline TX112 & 2 & -0.74 & 0.63 & 0.89 & 2.5 \\
\hline BY106 & 3 & -0.76 & 0.55 & 0.87 & 2.15 \\
\hline SX101 & 1 & -0.76 & 0.45 & 0.87 & 1.81 \\
\hline BX110 & 24 & -0.76 & 0.5 & 0.86 & 1.95 \\
\hline BY103 & 3 & -0.78 & 0.63 & 0.85 & 2.41 \\
\hline BY105 & 3 & -0.79 & 0.55 & 0.84 & 2.08 \\
\hline T101 & 19 & -0.81 & 0.64 & 0.82 & 2.36 \\
\hline
\end{tabular}


Table 4.13. (contd)

\begin{tabular}{|l|c|c|c|c|c||}
\hline \multicolumn{1}{|c|}{ Tank } & $\begin{array}{c}\text { SORWT } \\
\text { Number }\end{array}$ & $\begin{array}{c}\text { Mean Log } \\
\text { TOC }\end{array}$ & $\begin{array}{c}\text { SD Log } \\
\text { TOC }\end{array}$ & $\begin{array}{c}\text { Mean TOC } \\
\text { dry \% }\end{array}$ & $\begin{array}{c}\text { 95\% Confidence } \\
\text { Limit }\end{array}$ \\
\hline TX114 & 2 & -0.83 & 0.63 & 0.81 & 2.29 \\
\hline C110 & 11 & -0.84 & 0.64 & 0.8 & 2.28 \\
\hline T107 & 8 & -0.88 & 0.55 & 0.77 & 1.9 \\
\hline B110 & 15 & -0.91 & 0.64 & 0.75 & 2.15 \\
\hline TX118* & 22 & -0.96 & 0.37 & 0.71 & 1.3 \\
\hline BY102 & 21 & -1 & 0.55 & 0.68 & 1.69 \\
\hline S109 & 1 & -1.06 & 0.49 & 0.64 & 1.44 \\
\hline TX116 & 2 & -1.09 & 0.63 & 0.62 & 1.75 \\
\hline TY101 & 30 & -1.25 & 0.55 & 0.53 & 1.31 \\
\hline TY102 & 2 & -1.26 & 0.55 & 0.53 & 1.3 \\
\hline TY103 & 27 & -1.38 & 0.42 & 0.47 & 0.93 \\
\hline TX115 & 7 & -1.44 & 0.55 & 0.44 & 1.08 \\
\hline U110 & 17 & -1.52 & 0.35 & 0.4 & 0.72 \\
\hline$*$ Original watchlist tanks. & & & \\
\hline
\end{tabular}




\subsection{TOC Criteria for Watchlist Tanks}

The TOC and standard deviation estimates developed using the ANOVA model can be used to determine the likelihood of a tank exceeding 5\% TOC. The 5\% TOC threshold is established in Babad and Turner (1993). The likelihood a tank will exceed $5 \%$ can be expressed on an exceedance probability plot. The probability is expressed as a number less than 1,1 indicating $100 \%$ likelihood the tank exceeds $5 \%$ TOC.

The exceedance probability is given by the following equation:

$$
\operatorname{Pr}\left(\operatorname{Tank}_{\mathrm{ij}} \text { Mean }>5 \%\right)=\Phi\left[\frac{\log (5 \%)-\log \left(\mathrm{U}_{\mathrm{ij}}\right)}{\sigma_{\mathrm{ij}}}\right]
$$

where $\Phi$ is the normal probability function, $\log \left(u_{i j}\right)$ is given from equation 4.1 , and $\sigma_{i j}$ is standard deviation of the estimate for tank $\mathrm{ij}$.

The plots showing the probability that a tank will exceed $5 \%$ TOC are represented in Figures 4.10 , $4.11,4.12$, and 4.13 for wet-TOC median, wet-TOC mean, dry-TOC median and dry-TOC mean, respectively. The ten tanks with the greatest probability of exceeding 5\% TOC are listed on the plots in decreasing order. Sampled tanks tend to occur either at the high end or low end of the curve. Sampling tends to put the tank in a definite state, either higher or lower probability that the tank will exceed 5\% TOC compared to unsampled tanks. The results shown in Figures 4.10 through 4.13 should be used with caution. At a $1 / 1000$ probability level, many tanks would exceed the $5 \%$ threshold for the dry mean basis. As Figure 4.13 shows, many of these tanks are unmeasured tanks. 


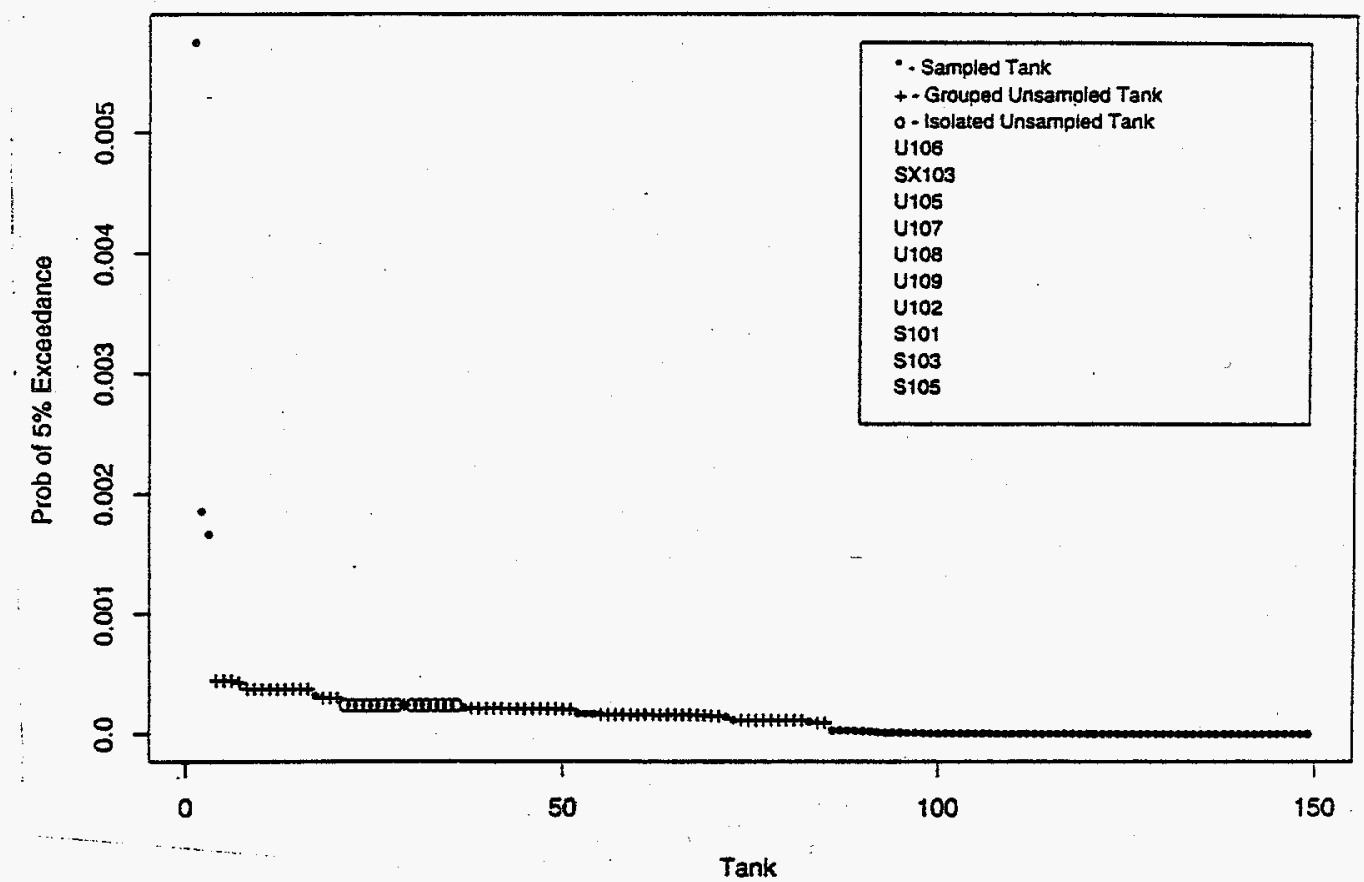

Figure 4.10. Probability of 5\% Exceedance for 149 SSTs, Wet Median Basis (Top ten tanks with highest probability of exceeding $5 \%$ are noted in the legend.)

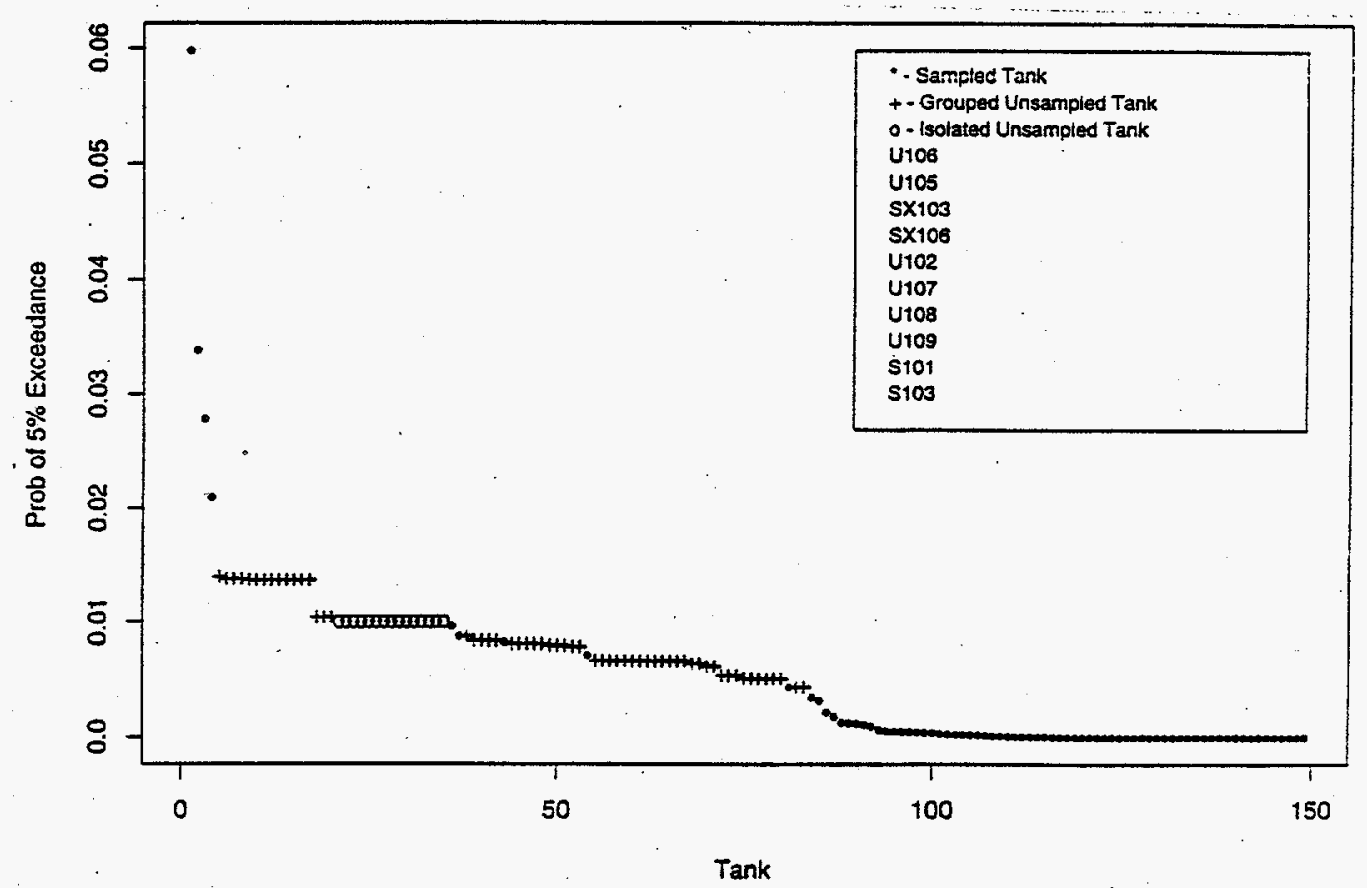

Figure 4.11. Probability of 5\% exceedance for 149 SSTs, Wet Mean Basis (Top ten tanks with highest probability of exceeding $5 \%$ are noted in the legend.) 


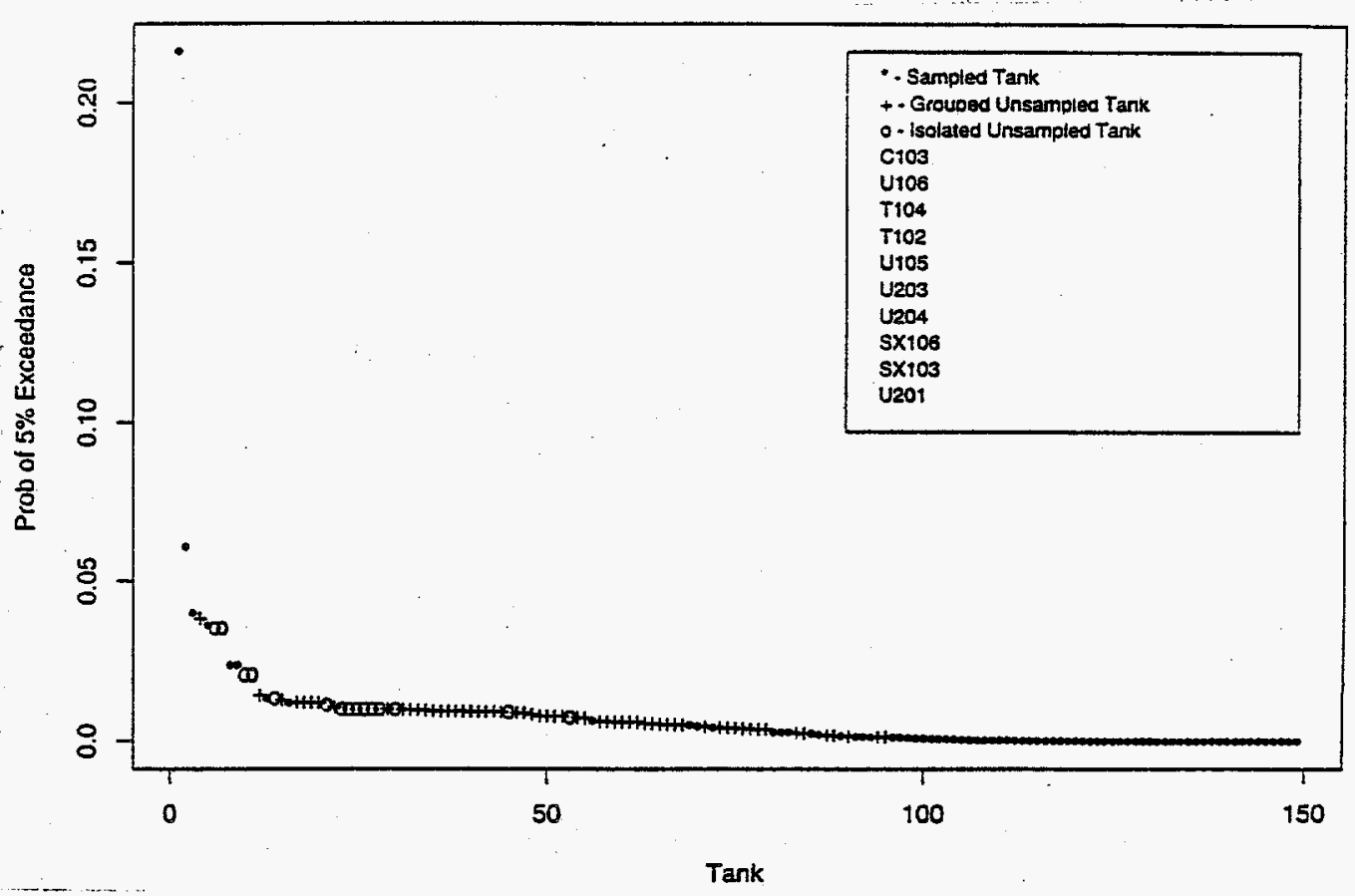

Figure 4.12. Probability of $5 \%$ Exceedance for 149 SSTs, Dry Median Basis (Top ten tanks with highest probability of exceeding $5 \%$ are noted in the legend.)

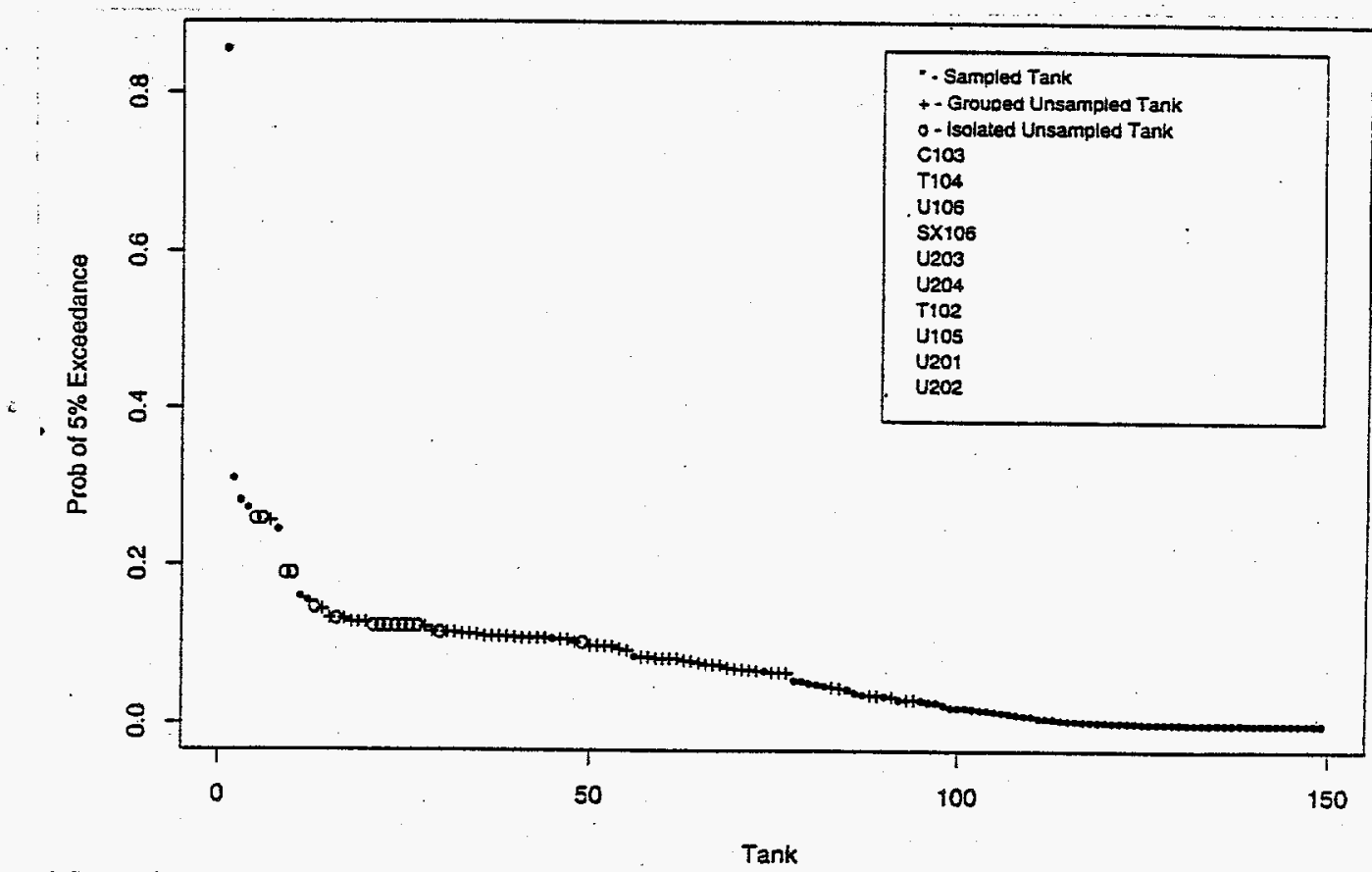

Figure 4.13. Probability of $5 \%$ Exceedance for 149 SSTs, Dry Mean Basis (Top 10 tanks with highest probability of exceeding $5 \%$ are noted in the legend.) 


\subsection{Conclusions and Recommendations}

\section{Conclusions}

To support the Tank Waste Remediation System Program at Hanford, it has been determined that a best estimate, including confidence level, of total organic carbon (TOC) for each of the 149 single-shell tanks (SSTs) is required. This document provides estimates and confidence levels for each of the 149 tanks, with a methodology and ranking under which additional SST monitoring or measuring can proceed for the Organic Tank Safety Program. The methodology makes use of chemical analysis information provided in tank process laboratory results and tank characterization reports. The methodology also makes use of an Analysis of Variance (ANOVA) statistical technique and a tank grouping method based on the different types of wastes introduced into each SST (SORWT grouping technique).

Characteristic reports and laboratory analytical results from 75 of the 149 SSTs at Hanford were provided. Most of the reports provide data on the liquid phase total organic carbon, but core composite, sludge, and salt cake data are also represented. Organic species measurements are not well characterized. When organic species data are reported, only EDTA and HEDTA are represented, and these account for only $10 \%$ of the TOC content. A significant number of tanks, 28 out of 75 , had only one TOC observation for the tank. Of the 149 SST tanks, 59 had no TOC measurement but did belong to a SORWT group with at least one observation. Another 15 tanks had no TOC measurement and belonged to a SORWT group that had no TOC measurements. It was shown in Section 4.7 that the SORWT grouping scheme is not statistically effective since the between-tank and within-tank standard deviations are much larger than the SORWT group standard deviation.

The data did not indicate any significant correlation of TOC values to waste phase (liquid or solids). There were no data clusters or grouping of liquid and solid phases. Therefore, waste phase dependence (solid, liquid) was not included in the statistical model for this study.

The TRAC inventories of organic components were used to estimate the total organic concentration of the 149 Hanford SSTs. The TRAC estimates of organic carbon are usually zero, and the method cannot be relied upon to give realistic estimates of organic carbon in the tanks. If a determination of organic carbon is required, a comparison of laboratory values within similar groups is recommended as a more accurate preliminary determination over the TRAC estimates.

Both median and mean TOC estimates for each tank are provided on a wet and dry basis (Tables 4.10 through 4.13). The TOC median values provide estimates that approximate the determination of TOC inventory added to the tanks according to Fisher (1990). Based on a wet median basis, the current study estimates the total carbon in all 149 SSTs to be 760 metric tons, and the Fisher (1990) study estimates quantity of organic carbon added to the tanks to be 850 metric tons. If the TOC mean is used in place of the median, the TOC added to the tanks is 1500 metric tons, well above the 
Fisher (1990) estimate. For best-estimate TOC values, it is recommended that the Table 4.10 values indicating wet basis median values be used. To be consistent with the organic safety watchlist criteria, the dry mean values are estimated and are provided in Table 4.13.

\section{Recommendations}

Although the TOC information compiled and modeled statistically in this report represents a significant improvement in our knowledge about TOC in single-shell tanks, the dataset could be improved upon. Specifically:

- Construct a TOC dataset that can be updated with additional TOC measurements as they become available.

- Determine TOC measurement bias with respect to individual laboratories and analytical technique employed.

- Evaluate measurement data and tanks with outlying observations in the dataset.

- Determine availability of information on TOC spatial variations. Include spatial variations in the statistical model.

- Validate the current TOC estimates with additional sampling results.

The tank grouping scheme should be simplified and improved. A recommended grouping technique is:

- Group 1 - tanks for which the transfer records show low TOC present.

- Group 2 - tanks that have an ambiguous transfer record.

- Group 3 - tanks for which transfer records show high TOC present. 


\subsection{References}

Babad, H., and D. A. Turner. September 1993. Interim Criteria for Organic Watch List Tanks at the Hanford Site. WHC-EP-0681, Westinghouse Hanford Company, Richland, Washington.

Fisher, F. D. August 1990. The Kyshtym Explosion and Explosion Hazards with Nitrate - Nitrite Bearing Waste with Acetates and Other Organic Salts. WHC-SD-CP-LB-033, Westinghouse Hanford Company, Richland, Washington.

Herting, D. L. et al. 1992. 1992 Tank 101-SY Characterization Report. WHC-SD-WM-DTR-026, Westinghouse Hanford Company, Richland, Washington.

Hill, J. G., and B. C. Simpson. August 1991. The Sort on Radioactive Waste Type Model: A Method to Sort Single Shell Tanks Into Characteristic Groups. WHC-EP-0449, Westinghouse Hanford Company, Richland, Washington.

Hill, J. G., W. I. Winters, B. C. Simpson, J. W. Buck, P. J. Chamberlain, and V. L. Hunter. September 1991. Waste Tank Characterization Plan for the Hanford Site Single-Shell Tanks, Appendix I - Test Plan for Sampling and Analysis of Ten Single-Shell Tanks. WHC-EP-0210, Rev. 3, Westinghouse Hanford Company, Richland, Washington.

Jensen, L. 1993. Characterization Report for Single-Shell Tank 241-U-110. WHC-SD-WM-TI-560, Rev 0., Westinghouse Hanford Company, Richland, Washington.

Jungfleisch, F. M. 1984. Preliminary Estimation of the Waste Inventories in Hanford Tanks Through 1980. SD-WM-TI-057, Rockwell Hanford Operations, Richland, Washington.

Schulz, W. W. January 1980. Removal of Radionuclides from Hanford Defense Waste Solutions. RHO-SA-51, Rockwell Hanford Operations, Richland, Washington. 


\section{Appendix A}

Laboratory Techniques 


\section{Appendix A}

\section{Laboratory Techniques}

The total organic carbon (TOC) is reported in the laboratory reports. All laboratory reports with units of measure are used. Laboratory measurements are covered from 1977 to the present, as shown in Appendix B.

Factors for converting laboratory measurements to Percent TOC are presented in Table A.1.

Table A.1. Conversion Factors for Laboratory Data

\begin{tabular}{|l|l|l|}
\hline Reported Lab Units of TOC & \multicolumn{1}{|c|}{ Conversion Factor } & Comments \\
\hline $\mathrm{gm} / \mathrm{gm}$ & 100 & \\
\hline $\mathrm{gm} / \mathrm{L}$ & $100 / 1000 / \mathrm{D}$ & $\mathrm{D}=$ density; default $=1.3$ \\
\hline $\mathrm{moles} / \mathrm{L}$ & $12.01 * 100 / 1000 / 1.3$ & \\
\hline $\mathrm{moles} / \mathrm{L}$ & $12.01 * 100 / 1000 / \mathrm{D}$ & \\
\hline ugm/gm & $100 / 1,000,000$ & \\
\hline
\end{tabular}

Where no density was reported with the measured TOC value, a density of 1.3 was assigned as a default value.

\section{Laboratory Measurements Techniques}

Two techniques were used to determine TOC, combustion and chemical oxidation.

In combustion, samples are burned in an oxygen atmosphere to convert the organic forms of carbon to $\mathrm{CO}_{2}$. The combustion temperature is selected (app $1100^{\circ} \mathrm{C}$ ) to oxidize the organic carbon components. The combustion products are swept through a barium chomate catalyst and scrubbed to insure complete oxidation of the carbon to $\mathrm{CO}_{2}$. Noncarbon combustion products such as $\mathrm{CO}_{2}$ and $\mathrm{NO}_{\mathrm{x}}$ are removed from the gas stream by a series of chemical scrubbers. The $\mathrm{CO}_{2}$ released is quantified in a $\mathrm{CO}_{2}$ calorimetry cell and the amount of TOC is calculated. Inorganic carbon is first 
removed from the sample before analysis by adding acid to convert the inorganic carbon to gaseous $\mathrm{CO}_{2}$. In the combustion samples, for solids, samples are diluted with water 1 part sample to make up 5 parts sample volume.

In chemical oxidation, the samples are oxidized with potassium persulfate or potassium permaganate to evolve $\mathrm{CO}_{2}$ in the presence of ultraviolet light.

Samples may have been contaminated, with NPH (normal pariffin hydrocarbon) during the core sampling procedure; therefore, some samples record higher than actual TOC measurements.

\section{TRAC Computer Code Inventory Evaluation}

The TRAC inventory dataset used was provided by WHC and is the dataset representing the inventories of waste for January 1990. The TOC calculations provided in this report match to the values of the TRAC/TOC calculations reported in Crippen (1991).

Details of Organic Carbon Constituents listed in the 1990 TRAC database are presented in Table A.2.

Table A.2. TRAC Label Description

\begin{tabular}{||l|l|l|l||}
\hline TRAC Label & \multicolumn{1}{|c|}{ Formula Name } & & \\
\hline $\mathrm{C} 2 \mathrm{H} 3 \mathrm{O} 3$ & Hydroxyacetate & HOCH & \\
\hline & $\mathrm{COO}-$ & [anion] \\
\hline $\mathrm{C} 6 \mathrm{H} 5 \mathrm{O} 7$ & Citrate & $-\mathrm{OOCCH}_{2} \mathrm{C}(\mathrm{OH})(\mathrm{COO}-) \mathrm{CH}_{2} \mathrm{COO}-$ & [anion] \\
\hline EDTA & Ethylenediamine $\mathrm{N}, \mathrm{N}, \mathrm{N}^{\prime}, \mathrm{N}$ 'tetraacetate & \\
\hline HEDTA & $\mathrm{N}$-(2-hydroxyethyl)-ethylene diamine $\mathrm{N}, \mathrm{N}^{\prime}, \mathrm{N}^{\prime}$-triacetate & [anion] \\
\hline C2O4 & Oxalate & - OOCCOO- & \\
\hline
\end{tabular}


The following conversion factors are used to change moles to grams of carbon employing the formula weights for each of the six species, as shown in Table A.3.

For each SST, the moles for each of the organic components are given in the TRAC database.

Table A.3. Conversion Factors for TRAC Organics

\begin{tabular}{|l|c|}
\hline $\begin{array}{c}\text { Moles of } \\
\text { Organic Species }\end{array}$ & Conversion Factor \\
\hline Hydroxyacetate & $2 * 12=24$ \\
\hline Citrate & $6 * 12=72$ \\
\hline Oxylate & $2 * 12=24$ \\
\hline EDTA & $10^{*} 12=120$ \\
\hline HEDTA & $10^{*} 12=120$ \\
\hline Fe(CN) & $6 * 12=72$ \\
\hline
\end{tabular}

\section{Example Conversion:}

Formula weight of carbon is 12 .

Moles Citrate $\left(\mathrm{C}_{6} \mathrm{H}_{5} \mathrm{O}_{7}\right) * 72=$ grams of carbon in citrate.

There are six carbons in each molecule of citrate. There are $6 \times 12$, or 72 grams of carbon, in each citrate mole. The conversion factor for citrate is $\mathbf{7 2}$.

\section{Total Mass:}

The moles of each constituent are multiplied by the formula weight of each constituent and summed to provide the total mass for each of the tanks for the solids and the liquids. The following species were used in the summation:

$\mathrm{Ag}, \mathrm{Al}, \mathrm{Ba}, \mathrm{Bi}, \mathrm{CO}_{3}, \mathrm{Ca}, \mathrm{Cd}, \mathrm{Ce}, \mathrm{CL}, \mathrm{Cr}, \mathrm{F}, \mathrm{Fe}, \mathrm{Hg}, \mathrm{K}, \mathrm{La}, \mathrm{Mn}, \mathrm{NO}_{2}, \mathrm{NO}_{3}, \mathrm{Na}, \mathrm{Ni}, \mathrm{OH}, \mathrm{PO}_{4}$, $\mathrm{Pb}, \mathrm{SeO}_{4}, \mathrm{SiO} 3, \mathrm{Sn}, \mathrm{SO}_{4}, \mathrm{Sr}, \mathrm{WO}_{4}, \mathrm{ZrO}$. 


\section{Conversion of TOC Data from Wet-to-Dry Basis}

Table A.4 provides the wet-to-dry basis correction factor, $\mathrm{C}_{\mathrm{W} / \mathrm{D}}$, as described in Section 4.6.

Table A.4. $\mathrm{C}_{\mathrm{W} / \mathrm{D}}=$ TOC Correction Factor Wet-to-Dry Basis

\begin{tabular}{|c|c|}
\hline Tank & Correction Factor, Wet-to-Dry Basis \\
\hline $101 \mathrm{~A}$ & 1.67 \\
\hline $102 \mathrm{~A}$ & 2.15 \\
\hline $103 \mathrm{~A}$ & 2.53 \\
\hline $104 \mathrm{~A}$ & 2.5 \\
\hline $105 \mathrm{~A}$ & 2.5 \\
\hline $106 \mathrm{~A}$ & 2.5 \\
\hline $101 \mathrm{AX}$ & 1.67 \\
\hline $102 \mathrm{AX}$ & 1.93 \\
\hline $103 \mathrm{AX}$ & 1.68 \\
\hline $104 \mathrm{AX}$ & 2.5 \\
\hline 101B & 2.5 \\
\hline 102B & 2.42 \\
\hline $103 \mathrm{~B}$ & 2.5 \\
\hline $104 B$ & 2.29 \\
\hline $105 B$ & 1.74 \\
\hline $106 \mathrm{~B}$ & 2.52 \\
\hline $107 \mathrm{~B}$ & 2.52 \\
\hline $108 \mathrm{~B}$ & 2.5 \\
\hline 109B & 2.5 \\
\hline $110 \mathrm{~B}$ & 2.51 \\
\hline $111 \mathrm{~B}$ & 2.51 \\
\hline 112B & 2.75 \\
\hline 201B & 2.59 \\
\hline
\end{tabular}

A.4 
Table A.4. (contd)

\begin{tabular}{|c|c|}
\hline Tank & Correction Factor, Wet-to-Dry Basis \\
\hline $202 B$ & 2.5 \\
\hline $203 B$ & 2.55 \\
\hline 204B & 2.55 \\
\hline 101BX & 2.56 \\
\hline 102BX & 2.5 \\
\hline 103BX & 2.66 \\
\hline 104BX & 2.57 \\
\hline 105BX & 2.68 \\
\hline 106BX & 3.71 \\
\hline 107BX & 2.51 \\
\hline 108BX & 2.5 \\
\hline 109BX & 2.5 \\
\hline 110BX & 2.46 \\
\hline 111BX & 2.04 \\
\hline 112BX & 2.52 \\
\hline 101BY & 1.84 \\
\hline 102BY & 1.67 \\
\hline 103BY & 1.67 \\
\hline 104BY & 1.72 \\
\hline 105BY & 1.72 \\
\hline 106BY & 1.75 \\
\hline 107BY & 1.8 \\
\hline 108BY & 2.15 \\
\hline 109BY & 1.78 \\
\hline 110BY & 1.82 \\
\hline 111BY & 1.69 \\
\hline
\end{tabular}

A. 5 
Table A.4. (contd)

\begin{tabular}{|l|l|}
\hline Tank & Correction Factor, Wet-to-Dry Basis \\
\hline $112 \mathrm{BY}$ & 1.68 \\
\hline $101 \mathrm{C}$ & 2.5 \\
\hline $102 \mathrm{C}$ & 2.5 \\
\hline $103 \mathrm{C}$ & 7.86 \\
\hline $104 \mathrm{C}$ & 2.5 \\
\hline $105 \mathrm{C}$ & 2.5 \\
\hline $106 \mathrm{C}$ & 2.91 \\
\hline $107 \mathrm{C}$ & 2.5 \\
\hline $108 \mathrm{C}$ & 2.5 \\
\hline $109 \mathrm{C}$ & 2.66 \\
\hline $110 \mathrm{C}$ & 2.5 \\
\hline $111 \mathrm{C}$ & 2.5 \\
\hline $112 \mathrm{C}$ & 2.5 \\
\hline $201 \mathrm{C}$ & 2.5 \\
\hline $202 \mathrm{C}$ & 2.68 \\
\hline $203 \mathrm{C}$ & 2.5 \\
\hline $204 \mathrm{C}$ & 2.5 \\
\hline $101 \mathrm{~S}$ & 2.5 \\
\hline $102 \mathrm{~S}$ & 2.13 \\
\hline $103 \mathrm{~S}$ & 1.67 \\
\hline $104 \mathrm{~S}$ & 2.51 \\
\hline $105 \mathrm{~S}$ & 2.67 \\
\hline $106 \mathrm{~S}$ & 2.67 \\
\hline $107 \mathrm{~S}$ & 2.5 \\
\hline $108 \mathrm{~S}$ & 2.5 \\
\hline $109 \mathrm{~S}$ & 2.5 \\
\hline & 2.5 \\
\hline
\end{tabular}

A. 6 
Table A.4. (contd)

\begin{tabular}{|l|l|}
\hline Tank & Correction Factor, Wet-to-Dry Basis \\
\hline $110 \mathrm{~S}$ & 1.88 \\
\hline $111 \mathrm{~S}$ & 1.84 \\
\hline $112 \mathrm{~S}$ & 1.67 \\
\hline $101 \mathrm{SX}$ & 1.82 \\
\hline $102 \mathrm{SX}$ & 1.8 \\
\hline $103 \mathrm{SX}$ & 1.77 \\
\hline $104 \mathrm{SX}$ & 1.8 \\
\hline $105 \mathrm{SX}$ & 1.73 \\
\hline $106 \mathrm{SX}$ & 1.9 \\
\hline $107 \mathrm{SX}$ & 2.5 \\
\hline $108 \mathrm{SX}$ & 2.5 \\
\hline $109 \mathrm{SX}$ & 2.5 \\
\hline $110 \mathrm{SX}$ & 2.5 \\
\hline $111 \mathrm{SX}$ & 2.5 \\
\hline $112 \mathrm{SX}$ & 2.5 \\
\hline $113 \mathrm{SX}$ & 2.53 \\
\hline $114 \mathrm{SX}$ & 2.5 \\
\hline $115 \mathrm{SX}$ & 2.5 \\
\hline $101 \mathrm{~T}$ & 2.53 \\
\hline $102 \mathrm{~T}$ & 2.21 \\
\hline $103 \mathrm{~T}$ & 2.54 \\
\hline $104 \mathrm{~T}$ & 2.5 \\
\hline $105 \mathrm{~T}$ & 2.5 \\
\hline $106 \mathrm{~T}$ & 2.5 \\
\hline $107 \mathrm{~T}$ & 2.5 \\
\hline $108 \mathrm{~T}$ & 2.5 \\
\hline & 2.5 \\
\hline
\end{tabular}

A. 7 
Table A.4. (contd)

\begin{tabular}{|c|c|}
\hline Tank & Correction Factor, Wet-to-Dry Basis \\
\hline $109 \mathrm{~T}$ & 2.5 \\
\hline $110 \mathrm{~T}$ & 2.52 \\
\hline $111 \mathrm{~T}$ & 2.51 \\
\hline $112 \mathrm{~T}$ & 2.79 \\
\hline $201 \mathrm{~T}$ & 2.59 \\
\hline $202 \mathrm{~T}$ & 2.5 \\
\hline $203 \mathrm{~T}$ & 2.5 \\
\hline $204 \mathrm{~T}$ & 2.5 \\
\hline $101 \mathrm{TX}$ & 2.59 \\
\hline $102 \mathrm{TX}$ & 1.67 \\
\hline $103 T X$ & 2.5 \\
\hline 104TX & 1.69 \\
\hline $105 \mathrm{TX}$ & 1.67 \\
\hline 106TX & 1.67 \\
\hline 107TX & 1.71 \\
\hline $108 \mathrm{TX}$ & 1.67 \\
\hline 109TX & 1.67 \\
\hline $110 \mathrm{TX}$ & 1.67 \\
\hline $111 \mathrm{TX}$ & 1.67 \\
\hline $112 \mathrm{TX}$ & 1.67 \\
\hline $113 \mathrm{TX}$ & 1.67 \\
\hline $114 \mathrm{TX}$ & 1.67 \\
\hline $115 \mathrm{TX}$ & 1.67 \\
\hline $116 \mathrm{TX}$ & 1.67 \\
\hline $117 \mathrm{TX}$ & 1.67 \\
\hline $118 \mathrm{TX}$ & 1.67 \\
\hline
\end{tabular}

A. 8 
Table A.4. (contd)

\begin{tabular}{|c|c|}
\hline Tank & Correction Factor, Wet-to-Dry Basis \\
\hline $101 T Y$ & 2.5 \\
\hline $102 T Y$ & 1.67 \\
\hline $103 T Y$ & 2.5 \\
\hline 104 TY & 2.67 \\
\hline $105 T Y$ & 2.5 \\
\hline $106 \mathrm{TY}$ & 2.5 \\
\hline $101 \mathrm{U}$ & 2.84 \\
\hline $102 U$ & 1.82 \\
\hline $103 \mathrm{U}$ & 1.76 \\
\hline $104 \mathrm{U}$ & 2.5 \\
\hline $105 \mathrm{U}$ & 1.88 \\
\hline $106 U$ & 1.86 \\
\hline $107 \mathrm{U}$ & 1.83 \\
\hline $108 \mathrm{U}$ & 1.8 \\
\hline $109 U$ & 1.8 \\
\hline $110 U$ & 2.5 \\
\hline $111 \mathrm{U}$ & 1.71 \\
\hline $112 U$ & 2.72 \\
\hline $201 U$ & 3.13 \\
\hline $202 \mathrm{U}$ & 3.13 \\
\hline $203 \mathrm{U}$ & 3.75 \\
\hline $204 \mathrm{U}$ & 3.75 \\
\hline
\end{tabular}


Appendix B

Laboratory Data 


\begin{tabular}{|c|c|c|c|c|c|c|c|}
\hline $\begin{array}{l}\text { Tank } \\
\text { Farm }\end{array}$ & Tank & $\begin{array}{c}\text { SORWT } \\
\text { Group }\end{array}$ & $\begin{array}{c}\text { Sample } \\
\text { ID }\end{array}$ & $\begin{array}{c}\text { Sample } \\
\text { Type }\end{array}$ & $\begin{array}{c}\text { Reference } \\
\text { Date }\end{array}$ & $\begin{array}{c}\% \\
\text { T.o.c }\end{array}$ & Reference \\
\hline A & 101 & DSSF-NCPLX & RAT-A101-3 & Filtrate & $10 / 22 / 80$ & 1.32 & I.L. 65453-80-336 Rockwell Int. \\
\hline A & 101 & DSSF-NCPLX & RAT-A101-4B & Filtrate & $11 / 10 / 80$ & 0.51 & I.L. 65453-80-337 Rockwell Int. \\
\hline A & 101 & DSSF-NCPLX & RAT-A101-5B & Filtrate & $11 / 11 / 80$ & 0.69 & I.L. 65453-80-337 Rockwell Int. \\
\hline A & 101 & DSSF-NCPLX & RAT-A101-7B & Filtrate & $11 / 02 / 79$ & 1.45 & I.L. 65124-79-005 Rockwell Int. \\
\hline A & 101 & DSSF-NCPLX & 4493 & Sludge & $09 / 22 / 80$ & 0.76 & I.L. 65453-80-267 Rockwell Int. \\
\hline A & $10 t$ & DSSF-NCPLX & RAT-A101-4A & Slurry & $11 / 10 / 80$ & 0.58 & I.L. 65453-80-337 Rockwell Int. \\
\hline A & 101 & DSSF-NCPLX & RAT-A101-5A & Slurry & $11 / 11 / 80$ & 0.84 & I.L. 65453-80-337 Rockwell Int. \\
\hline A & 101 & DSSF-NCPLX & 7879 & Slurry & 10/10/83 & 6.20 & I.L. 65453-80-003 Rockwell Int. \\
\hline A & 101 & DSSF-NCPLX & 7898 & Slurry & 10/11/83 & 7.16 & I.L. 65453-84-003 Rockwell Int. \\
\hline A & 101 & DSSF-NCPLX & 4218 & Supernate & $09 / 22 / 80$ & 1.21 & I.L. 65453-80-267 Rockwell Int. \\
\hline A & 101 & DSSF-NCPLX & 4378 & Supernate & $09 / 22 / 80$ & 0.89 & I.L. 65453-80-267 Rockwell Int. \\
\hline A & 101 & DSSF-NCPLX & RAT-A101-1 & Supernate & $10 / 13 / 80$ & 0.82 & I.L. 65453-80-302 Rockwell Int. \\
\hline A & 101 & DSSF-NCPLX & RAT-A101-2 & Supernate & $10 / 13 / 80$ & 0.90 & I.L. 65453-80-302 Rockwell Int. \\
\hline A & 101 & DSSF-NCPLX & $\mathrm{T}-2691$ & Supernate & 08/22/80 & 2.74 & I.L. 65453-80-241 Rockwell Int. \\
\hline A & 101 & DSSF-NCPLX & $\mathrm{T}-2692$ & Supernate & $08 / 22 / 80$ & 3.36 & I.L. 65453-80-241 Rockwell Int. \\
\hline A & 101 & DSSF-NCPLX & 7879 & Supernate & 10/10/83 & 0.40 & 1.L. 65453-84-003 Rockwell Int. \\
\hline A & 101 & DSSF-NCPLX & 7898 & Supernate & 10/11/83 & 0.84 & I.L. 65453-84-003 Rockwell Int. \\
\hline A & 102 & DSSF-NCPLX & RAT-A102-1 & Filtrate & $12 / 23 / 80$ & 0.12 & I.L. 65453-80-395 Rockwell Int. \\
\hline A. & 102 & DSSF-NCPLX & 910X00XX & Liquor & 03/06/86 & 0.53 & SD-RE-TI-201 Rev. 0 \\
\hline A & 102 & DSSF-NCPLX & 92DX00XX & Liquor & 03/08/86 & 0.51 & SD-RE-TI-201 Rev. 0 \\
\hline A & 102 & DSSF-NCPLX & $91 \times C 00 x x$ & Sludge/Composite & 03/06/86 & 0.72 & SD-RE-TI-201 Rev. 0 \\
\hline A & 102 & DSSF-NCPLX & $92 x \operatorname{cooxx}$ & Sludge/Composite & 03/08/86 & 0.79 & SD-RE-TI-201 Rev. 0 \\
\hline A & 102 & DSSF-NCPLX & R-4656 & Supernate & 03/14/89 & 0.96 & I.M. 12712-PCL89-112 Rev. 1 WHC \\
\hline A & 102 & DSSF-NCPLX & RAT-A102-3 & Supernate & $10 / 23 / 79$ & 0.21 & I.L. 65124-79-170 Rockwell Int. \\
\hline A & 102 & DSSF-NCPLX & RAT-A102-4 & Supernate & $03 / 14 / 79$ & 0.35 & I.L. 60120-79-044 Rockwell Int. \\
\hline A & 102 & DSSF-NCPLX & $T-1243$ & Supernate & $07 / 17 / 80$ & 0.00 & I.L. 65453-80-200 Rockwell Int. \\
\hline A & 102 & DSSF-NCPLX & $T-1244$ & Supernate & $07 / 17 / 80$ & 0.35 & I.L. 65453-80-200 Rockwell Int. \\
\hline A & 102 & DSSF-NCPLX & $T-1245$ & Supernate & $07 / 17 / 80$ & 0.29 & I.L. 65453-80-200 Rockwell Int. \\
\hline A & 102 & DSSF-NCPLX & T-2404 & Supernate & 08/04/80 & 0.49 & I.L. 65453-80-213 Rockwell Int. \\
\hline A & 102 & DSSF-NCPLX & $T-2405$ & Supernate & 08/04/80 & 0.53 & I.L. 65453-80-213 Rockwell Int. \\
\hline A & 102 & DSSF-NCPLX & T-6176 & Supernate & $12 / 08 / 79$ & 0.40 & I.L. from Manger, Services \\
\hline A & 103 & DSSF-NCPLX & B1XD00XX & Liquor & $03 / 26 / 86$ & 0.57 & SD-RE-TI-198 Rev. 0 \\
\hline A & 103 & DSSF-NCPLX & $B 2 \times D 00 X X$ & Liquor & 04/03/86 & 0.56 & SD-RE-Ti-198 Rev. 0 \\
\hline A & 103 & DSSF-NCPLX & $B 1 \times C 00 x x$ & Sludge/Composite & 03/26/86 & 0.80 & SD-RE-TI-198 ReV. 0 \\
\hline A & 103 & DSSF-NCPLX & $\mathrm{B} 2 \mathrm{X} \operatorname{co0} \mathrm{XX}$ & Sludge/Composite & 04/03/86 & 0.77 & SD-RE-TI-198 Rev. 0 \\
\hline A & 103 & DSSF-NCPLX & RAT-A103-5 & Supernate & $10 / 02 / 80$ & 0.35 & I.L. 65453-80-287 Rockwell Int. \\
\hline A & 103 & DSSF-NCPLX & RAT-A103-6 & Supernate & $09 / 22 / 80$ & 1.00 & I.L. $65453-80-266$ Rockwell Int. \\
\hline A & 103 & DSSF-NCPLX & RAT-At03-7 & Supernate & 08/02/79 & 1.10 & I.L. 65120-79-123 Rockwell Int. \\
\hline A & 103 & DSSF-NCPLX & $T-8951$ & Supernate & $03 / 19 / 80$ & 0.64 & I.L. Manger, Services Rockwell Int \\
\hline A & 106 & UNGROUPED & A1XD00XX & Liquor & 03/11/86 & 0.42 & SD-RE-TI-200 Rev.0 \\
\hline A & 106 & UNGROUPED & A2XD00XX & Liquor & 03/13/86 & 0.01 & SD-RE-TI-200 Rev.0 \\
\hline A & 106 & UNGROUPED & Riser 17 & Solid & $01 / 05 / 88$ & 0.62 & SD-RE-TI-200 Rev. 0 \\
\hline A & 106 . & UNGROUPED & Riser 20 & Solid & $01 / 05 / 88$ & 0.72 & SD-RE-TI-200 Rev. 0 \\
\hline A & 106 & UNGROUPED & A1Xc00xx & Sludge/Composite & 03/11/86 & 0.62 & SD-RE-TI-200 Rev.0 \\
\hline A & 106 & UNGROUPED & $A 2 X \cos X X$ & Sludge/Composite & 03/13/86 & 0.72 & SD-RE-TI-200 Rev.0 \\
\hline $\mathbf{A X}$ & 101 & DSSF & 5169 & Supernate & $10 / 07 / 80$ & 0.53 & I.L. 65453-80-293 Rockwell Int. \\
\hline $\mathbf{A X}$ & 101 & DSSF-NCPLX & RAT-AX101-2 & Supernate & $11 / 11 / 80$ & 1.10 & I.L. 65453-80-331 Rockwell Int. \\
\hline$A X$ & 101 & DSSF-NCPLX & RAT-AX101-3 & Supernate & $11 / 11 / 80$ & 1.08 & I.L. 65453-80-331 Rockwell Int. \\
\hline $\mathbf{A X}$ & 101 & DSSF-NCPLX & T-3102 & Supernate & $08 / 19 / 80$ & 0.90 & I.L. 65453-80-233 Rockwell int. \\
\hline
\end{tabular}

\begin{tabular}{|c|c|c|c|}
\hline Analyte & Value & Units & $\begin{array}{l}\text { SORWT } \\
\text { GROUP \# }\end{array}$ \\
\hline TOC & 19.1 & $\mathrm{gm} / \mathrm{I}$ & 9 \\
\hline TOC & 7.51 & $\mathrm{gm} / \mathbf{l}$ & 9 \\
\hline TOC & 9.94 & $\mathbf{g m} /$ & 9 \\
\hline TOC & 20 & $\mathrm{gm} / \mathrm{I}$ & 9 \\
\hline TOC & 11.025 & $\mathrm{gm} / \mathrm{l}$ & 9 \\
\hline TOC & 9.51 & $\mathrm{gm} / \mathrm{l}$ & 9 \\
\hline TOC & 15.61 & $\mathbf{g m} / \mathbf{l}$ & 9 \\
\hline TOC & 7.02 & moles/ & \\
\hline TOC & 9.78 & moles/ & \\
\hline TOC & 16.24 & $\mathrm{gm} / \mathrm{l}$ & \\
\hline TOC & 10.14 & $\mathbf{g m} / \mathbf{l}$ & $g$ \\
\hline TOC & 10.71 & $\mathrm{gm} / 1$ & \\
\hline TOC & 11.52 & $\mathbf{g m} / \mathbf{1}$ & \\
\hline TOC & 35.16 & gm/l & \\
\hline TOC & 43.79 & $\mathbf{g m} /$ & \\
\hline TOC & 5.23 & moles/ & \\
\hline TOC & 11 & moles/1 & \\
\hline TOC & 1.79 & $\mathrm{gm} / \mathrm{I}$ & 9 \\
\hline TOC & 8.06 & $\mathrm{gm} / \mathrm{I}$ & \\
\hline TOC & 7.68 & $\mathbf{g m} / \mathbf{l}$ & \\
\hline TOC & 7200 & ugm/gm & \\
\hline TOC & 7940 & ugm/gm & \\
\hline TOC & 12.5 & $\mathrm{gm} /$ & \\
\hline TOC & 2.44 & $\mathbf{g m /}$ & \\
\hline TOC & 4.5 & gm/l & \\
\hline TOC & 0 & gm/l & \\
\hline TOC & 4.06 & $\mathrm{gm} /$ & \\
\hline TOC & 3.38 & gm/ & \\
\hline TOC & 5.82 & gm/ & \\
\hline Toc & 6.34 & gmil & \\
\hline TOC & 4.88 & $\mathrm{gm} / \mathrm{I}$ & \\
\hline TOC & 8.36 & $\mathrm{gm} / \mathrm{I}$ & \\
\hline TOC & 8.26 & $\mathrm{gm} /$ & \\
\hline TOC & 8040 & ugm/gm & \\
\hline TOC & 7730 & $\mathrm{ugm} / \mathrm{gm}$ & \\
\hline TOC & 4.95 & $\mathrm{gm} / \mathrm{I}$ & \\
\hline TOC & 14.4 & $\mathrm{gm} / \mathrm{h}$ & \\
\hline roc & 15.4 & $\mathrm{gm} / \mathrm{l}$ & 9 \\
\hline TOC & 7.92 & $\mathrm{gm} / \mathrm{l}$ & \\
\hline TOC & 5.64 & $g m / 1$ & 30 \\
\hline TOC & 0.13 & $\mathbf{g} \mathbf{m} / \mathbf{I}$ & 30 \\
\hline TOC & 0.62 & wt. $\%$ & 30 \\
\hline TOC & 0.72 & wt.\% & 30 \\
\hline TOC & 6230 & ugm/gm & 30 \\
\hline TOC & 7150 & $\mathrm{ugm} / \mathrm{gm}$ & 30 \\
\hline TOC & 7.46 & $\mathrm{gm} / \mathrm{l}$ & 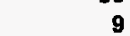 \\
\hline TOC & 15 & gm/l & \\
\hline TOC & 15 & $\mathrm{gm} / \mathrm{I}$ & \\
\hline TOC & 13 & $\mathrm{gm} / 1$ & \\
\hline
\end{tabular}

Note: All Laboratory Measurements in Appendix B are wet or "as-is" values. 


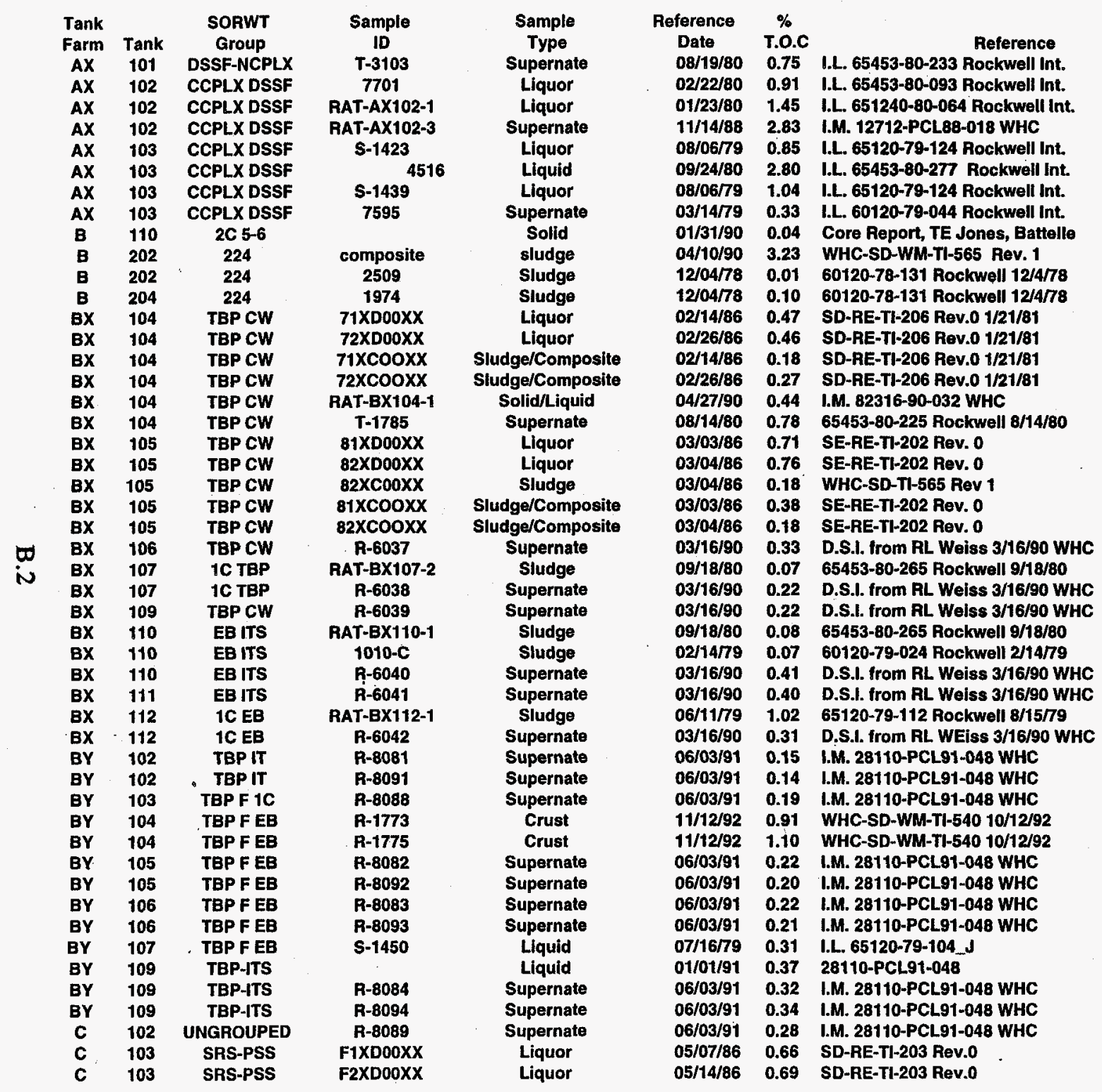

\begin{tabular}{|c|c|c|c|}
\hline $\begin{array}{c}\text { Analyte } \\
\text { TOC }\end{array}$ & $\begin{array}{l}\text { Value } \\
11.4\end{array}$ & $\begin{array}{l}\text { Units } \\
\text { gm/l }\end{array}$ & $\begin{array}{r}\text { SORWT } \\
\text { GROUP \# } \\
\mathbf{9}\end{array}$ \\
\hline TOC & 9.75 & $\mathbf{g m} /$ & 28 \\
\hline TOC & 16.1 & $\mathrm{gm} / \mathrm{l}$ & 28 \\
\hline TOC & 36.8 & $\mathrm{gm} / \mathrm{l}$ & 28 \\
\hline TOC & 12.3 & $g m / 1$ & 28 \\
\hline TOC & 2.80 & wt.\% & 28 \\
\hline TOC & 15 & gm/l & 28 \\
\hline TOC & 4.3 & gm/l & 28 \\
\hline TOC & 0.04 & wt.\% & 15 \\
\hline TOC & 32300 & ug/g & 5 \\
\hline TOC & 0.108 & $\mathbf{g m} / \mathbf{l}$ & 5 \\
\hline TOC & 0.096 & moles/l & 5 \\
\hline TOC & 6.18 & $\mathbf{g m} / \mathbf{l}$ & 4 \\
\hline TOC & 5.62 & $\mathbf{g m} / \mathbf{l}$ & 4 \\
\hline TOC & 1780 & ugm/gm & 4 \\
\hline TOC & 2710 & ugm/gm & 4 \\
\hline TOC & 5.7 & gmi & 4 \\
\hline TOC & 8.18 & $\mathbf{g m} / \mathbf{l}$ & 4 \\
\hline TOC & 9.12 & $\mathrm{gm} / \mathrm{l}$ & 4 \\
\hline Toc & 9.75 & $\mathrm{gm} / \mathrm{l}$ & 4 \\
\hline TOC & 1800 & ug/g & 4 \\
\hline TOC & 3760 & ugm/gm & 4 \\
\hline TOC & 1800 & ugm/gm & 4 \\
\hline TOC & 4.4 & $\mathbf{g m} / \mathbf{l}$ & 4 \\
\hline TOC & 0.00073 & $\mathrm{gm} / \mathrm{gm}$ & 11 \\
\hline TOC & 2.7 & $\mathrm{gm} / \mathrm{l}$ & 11 \\
\hline TOC & 3 & $\mathbf{g m} / \mathbf{l}$ & 4 \\
\hline TOC & 0.000769 & $\mathrm{gm} / \mathrm{gm}$ & 3 \\
\hline TOC & 0.07 & wt.\% & 3 \\
\hline TOC & 5.6 & $\mathbf{g m} / \mathbf{l}$ & 3 \\
\hline TOC & 5.7 & gm/l & 24 \\
\hline TOC & 0.01015 & $\mathrm{gm} / \mathrm{gm}$ & 12 \\
\hline TOC & 3.73 & $\mathrm{gm} / \mathrm{l}$ & 12 \\
\hline TOC & 2.2 & gm/l & 21 \\
\hline TOC & 2 & $\mathrm{gm} / \mathrm{l}$ & 21 \\
\hline TOC & 2.73 & $\mathbf{g m} / \mathbf{l}$ & 3 \\
\hline TOC & 9100 & ugm/gm & 3 \\
\hline TOC & 11000 & ugm/gm & 3 \\
\hline TOC & 3.06 & $\mathrm{gmin}$ & 3 \\
\hline TOC & 2.79 & $\mathbf{g} \mathbf{m} / \mathbf{I}$ & 3 \\
\hline TOC & 3.28 & $\mathrm{gm} / \mathrm{I}$ & 3 \\
\hline TOC & 3.04 & gm/l & $\mathbf{3}$ \\
\hline TOC & 4 & gm/I & 3 \\
\hline TOC & 0.37 & wt.\% & 21 \\
\hline TOC & 4.1 & $\mathbf{g m} / \mathbf{l}$ & 21 \\
\hline TOC & 4.77 & $\mathbf{g m} / \mathbf{l}$ & 21 \\
\hline Toc & 3.2 & $\mathbf{g m} / \mathbf{l}$ & 30 \\
\hline TOC & 7.37 & $\mathbf{g m} / \mathbf{l}$ & 23 \\
\hline TOC & 7.5 & $\mathrm{gm} / \mathrm{l}$. & 23 \\
\hline
\end{tabular}




\begin{tabular}{|c|c|c|}
\hline $\begin{array}{l}\text { Tank } \\
\text { Farm }\end{array}$ & Tank & $\begin{array}{c}\text { SOAWT } \\
\text { Group }\end{array}$ \\
\hline c & 103 & SRS-PSS \\
\hline c & 103 & SRS-PSS \\
\hline c & 103 & SRS-PSS \\
\hline c & 103 & SRS-PSS \\
\hline c & 103 & SRS-PSS \\
\hline c & 103 & SRS-PSS \\
\hline c & 103 & SRS-PSS \\
\hline c & 104 & UNGROUPED \\
\hline c & 104 & UNGROUPED \\
\hline c & 105 & UNGROUPED \\
\hline c & 105 & UNGROUPED \\
\hline c & 106 & SRS-PSS \\
\hline c & 106 & SRS-PSS \\
\hline c & 106 & SRS-PSS \\
\hline c & 106 & SRS-PSS \\
\hline C & 107 & UNGROUPED \\
\hline c & 110 & 1C,TBP \\
\hline c & 112 & TBP-F $1 \mathrm{C}$ \\
\hline c & 112 & TBP-F $1 C$ \\
\hline C & 112 & TBP-F IC \\
\hline c & 201 & HS \\
\hline $\mathbf{s}$ & 102 & REB \\
\hline $\mathbf{s}$ & 102 & REB \\
\hline $\mathbf{s}$ & 104 & $\mathbf{R}$ \\
\hline$\omega$ & 107 & REB \\
\hline s & 107 & REB \\
\hline $\mathbf{s}$ & 107 & REB \\
\hline $\mathbf{s}$ & 107 & R EB \\
\hline $\mathbf{s}$ & 107 & R EB \\
\hline $\mathbf{s}$ & 109 & R EB \\
\hline $\mathbf{s}$ & 110 & R EB \\
\hline $\mathbf{s}$ & 111 & R EB \\
\hline $\mathbf{s}$ & 111 & R EB \\
\hline $\mathbf{s}$ & 111 & REB \\
\hline $\mathbf{s}$ & 111 & REB \\
\hline $\mathbf{s}$ & 111 & REB \\
\hline $\mathbf{s}$ & 111 & R EB \\
\hline sx & 101 & R EB \\
\hline sx & 101 & REB \\
\hline sx & 101 & R EB \\
\hline sx & 101 & REB \\
\hline sx & 102 & R EB \\
\hline$s x$ & 102 & $R E B$ \\
\hline sx & 103 & REB \\
\hline sx & 103 & R EB \\
\hline $\mathbf{s x}$ & 104 & R EB \\
\hline $\mathbf{s x}$ & 104 & R EB \\
\hline sx & 104 & R EB \\
\hline sx & 106 & REB \\
\hline
\end{tabular}

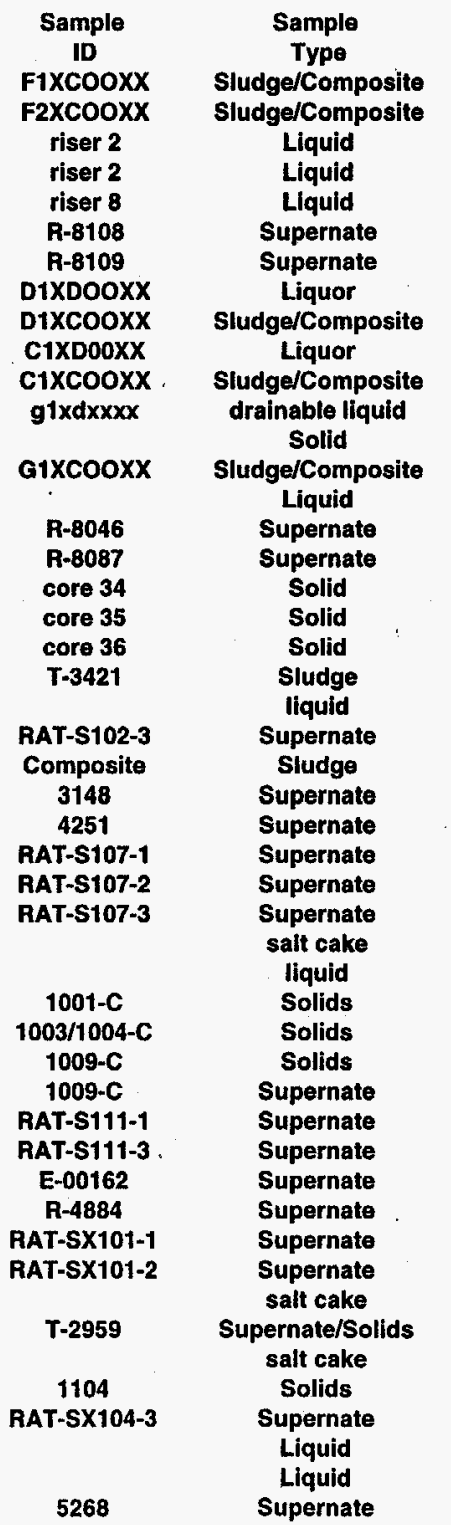

\begin{tabular}{|c|c|c|}
\hline Date & T.O.c & Reference \\
\hline $05 / 07 / 86$ & 0.39 & SD-RE-TI-203 Rev.0 \\
\hline 05/14/86 & 0.26 & SD-RE-TI-203 Rev.0 \\
\hline 05/19/87 & 0.57 & WHC 13311C-88-049 \\
\hline 05/19/87 & 0.57 & WHC 13311C-88-049 \\
\hline 05/19/87 & 0.55 & WHC 13311C-88-049 \\
\hline 06/03/91 & 0.70 & I.M. 28110-PCL91-048 WHC \\
\hline 06/03/91 & 0.70 & I.M. 28110-PCL91-048 WHC \\
\hline 04/15/86 & 0.87 & SD-RE-TI-199 Rev.0 1/21/88 \\
\hline 04/15/86 & 0.44 & SD-RE-TI-199 Rev.0 1/21/88 \\
\hline 04/11/86 & 0.23 & SD-RE-TI-204 Rev.0 1/8/88 \\
\hline 04/11/86 & 0.10 & SD-RE-TI-204 Rev.0 1/8/88 \\
\hline 05/19/86 & 0.19 & WHC-SD_CP-LB-033 \\
\hline 05/08/87 & 0.08 & WHC 13311C-88-049 \\
\hline 05/19/86 & 0.46 & SD-RE-TI-205 Rev.0 1/8/88 \\
\hline 09/18/80 & 0.19 & IL 65453-80-265 Rockwell \\
\hline 06/03/91 & 0.09 & I.M. 28110-PCL91-048 \\
\hline 06/03/91 & 0.05 & I.M. 28110-PCL91-048 \\
\hline 04/01/93 & 0.58 & WHC EP 0640 \\
\hline 04/01/93 & 0.29 & WHC EP 0640 \\
\hline 04/01/93 & 0.87 & WHC EP 0640 \\
\hline $12 / 04 / 78$ & 0.21 & 60120-78-132 12/4/78 JE Horton \\
\hline $01 / 01 / 80$ & 2.42 & Schutz, 1980 \\
\hline $01 / 31 / 79$ & 0.84 & 65120-79-062 Rockwell 4/5/79 \\
\hline 04/13/90 & 0.23 & WHC-SD-WM-TI-565 \\
\hline 09/07/78 & 0.88 & 60120-78-091 Rockwell 9/7/78 \\
\hline 10/16/78 & 0.26 & 60120-78-106 Rockwell 10/16/78 \\
\hline $04 / 27 / 90$ & 0.31 & I.M. 82316-90-032 \\
\hline 09/22/80 & 0.63 & 65453-80-270 Rockwell 9/22/80 \\
\hline $09 / 22 / 80$ & 0.75 & 65453-80-270 Rockwell 9/22/80 \\
\hline 01/01/80 & 0.05 & Schutz, 1980 \\
\hline $01 / 01 / 80$ & 1.25 & RHO-SA-51 \\
\hline $08 / 25 / 78$ & 0.10 & I.L. 60120-78-087 Rockwell 8/25/75 \\
\hline 08/25/78 & 0.89 & I.L. 60120-78-087 Rockwell 8/25/75 \\
\hline $08 / 25 / 78$ & 2.34 & I.L. 60120-78-087 Rockwell 8/25/75 \\
\hline 08/25/78 & 0.42 & I.L. 60120-78-087 Rockwell 8/25/75 \\
\hline $04 / 27 / 90$ & 0.28 & I.M. 82316-90-032 WHC 4/27/90 \\
\hline $08 / 25 / 78$ & 0.40 & I.L. 60120-78-087 Rockwell 8/25/75 \\
\hline $02 / 07 / 79$ & 0.24 & I.L. 60120-79-016 Rockwell 2/7/79 \\
\hline 04/26/89 & 0.03 & I.M. 12712-PCL90-043 WHC 2/22/90 \\
\hline $10 / 29 / 80$ & 0.38 & I.L. 65453-80-316 Rockwell 10/29/80 \\
\hline $10 / 29 / 80$ & 0.57 & I.L. 65453-80-316 Rockwell 10/29/80 \\
\hline $01 / 01 / 80$ & 0.20 & Schultz, 1980 \\
\hline 09/03/80 & 0.82 & I.L. 65453-80-250 Rockwell 9/3/80 \\
\hline 01/01/80 & 0.20 & Schultz, 1980 \\
\hline 10/10/77 & 4.60 & I.L. from JL Starr Rockwell 12/16/7 \\
\hline 05/14/88 & 0.33 & I.M. 12221-PCL88-147 WHC 8/15/88 \\
\hline 08/15/88 & 0.25 & WHC IL. 12221-PCL88-147 \\
\hline 08/15/88 & 0.11 & WHC IL. 12221-PCL88-147 \\
\hline $11 / 13 / 78$ & 0.09 & 60120-78-149 Rockwell 12/22/78 \\
\hline
\end{tabular}

\begin{tabular}{|c|c|c|c|}
\hline \multicolumn{4}{|r|}{ SORWT } \\
\hline $\begin{array}{c}\text { Analyte } \\
\text { TOC }\end{array}$ & $\begin{array}{l}\text { Value } \\
\quad 3900\end{array}$ & $\begin{array}{l}\text { Units } \\
\text { ugm/gm }\end{array}$ & GROUP : \\
\hline TOC & 2630 & $\mathrm{ugm} / \mathrm{gm}$ & \\
\hline TOC. & 0.57 & wt.\% & \\
\hline TOC & 0.57 & $w t . \%$ & \\
\hline roc & 0.55 & wt.\% & \\
\hline TOC & 7.46 & $\mathrm{gm} / \mathrm{l}$ & \\
\hline TOC & 7.44 & $\mathrm{gm} / \mathrm{I}$ & \\
\hline TOC & 10.3 & gm/ & \\
\hline TOC & 4410 & ugm/gm & \\
\hline TOC & 2.87 & $g \mathrm{mn}$ & \\
\hline TOC & 999 & ugm/gm & \\
\hline TOC & 2.52 & $\mathrm{gm} / \mathrm{h}$ & \\
\hline TOC & 0.08 & wt.\% & \\
\hline TOC & 4620 & ugm/gm & \\
\hline TOC & 0.19 & wt.\% & \\
\hline TOC & 1.03 & $\mathbf{g m} /$ & \\
\hline TOC & 0.632 & $\mathrm{gm} / \mathrm{l}$ & \\
\hline TOC & 0.58 & wt.\% & \\
\hline TOC & 0.29 & wt.\% & \\
\hline TOC & 0.87 & wt.\% & \\
\hline TOC & 0.2 & moles/ & \\
\hline TOC & 2.63 & moles/l & \\
\hline TOC & 10.6 & $\mathrm{gm} / \mathrm{l}$ & \\
\hline TOC & 2280 & ug/g & \\
\hline Toc & 11.8 & $\mathrm{gm} / 1$ & \\
\hline TOC & 4 & $\mathbf{g} \mathbf{m} /$ & \\
\hline Toc & 4 & $\mathrm{gm} / \mathrm{l}$ & \\
\hline TOC & 9 & $\mathrm{gm} / \mathrm{l}$ & \\
\hline TOC & 8.28 & $\mathrm{gm} /$ & \\
\hline TOC & 0.051 & moles/1 & \\
\hline TOC & 1.25 & wt.\% & \\
\hline TOC & 1.29 & $\mathbf{g m} / \mathbf{l}$ & \\
\hline TOC & 1.38 & moles/ & \\
\hline Toc & 2.8 & moles/ & \\
\hline TOC & 6.2 & $\mathrm{gm} / \mathrm{l}$ & \\
\hline TOC & 4.2 & $\mathbf{g m} / \mathbf{I}$ & \\
\hline TOC & 6 & $\mathrm{gm} / \mathrm{I}$ & \\
\hline TOC & 3.12 & $\mathrm{gm} /$ & \\
\hline TOC & 0.32 & $\mathrm{gm} / \mathrm{l}$ & \\
\hline TOC & 0.326 & moles/l & \\
\hline TOC & 0.484 & moles/1 & \\
\hline TOC & 0.21 & moles I & \\
\hline TOC & 12.7 & $\mathbf{g m} /$ & \\
\hline TOC & 0.21 & moles/ & \\
\hline TOC & 92 & $\mathrm{gm} / \mathrm{l}$ & \\
\hline TOC & 5 & $\mathrm{gm} / \mathbf{l}$ & \\
\hline TOC & 0.25 & wt.\% & \\
\hline TOC & 0.11 & wt.\% & \\
\hline TOC & 1.2 & $\mathrm{am} /$ & \\
\hline
\end{tabular}




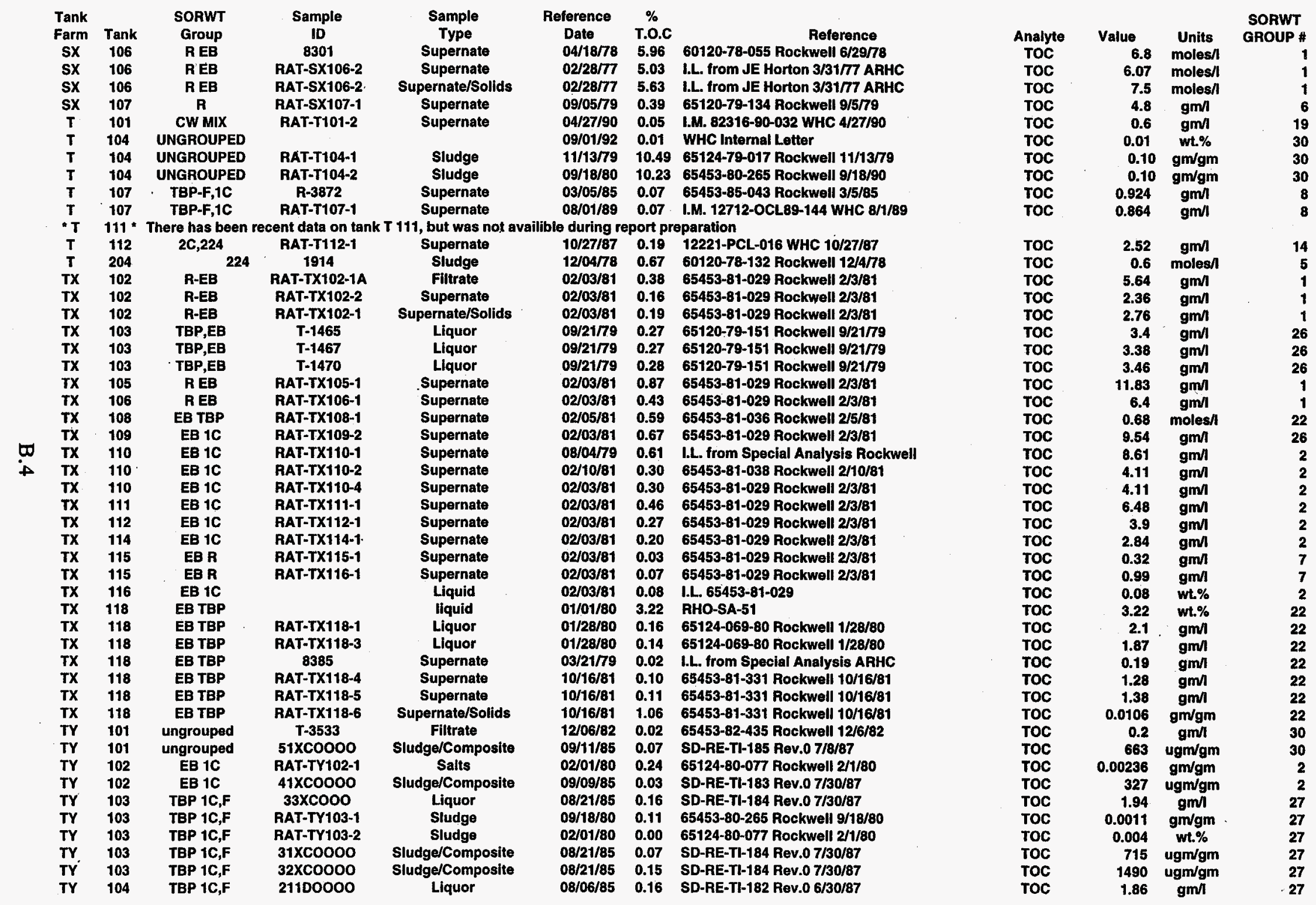




\begin{tabular}{|c|c|c|c|c|c|c|c|c|c|c|c|}
\hline $\begin{array}{l}\text { Tank } \\
\text { Farm }\end{array}$ & Tank & $\begin{array}{c}\text { SORWT } \\
\text { Group }\end{array}$ & $\begin{array}{c}\text { Sample } \\
\text { ID }\end{array}$ & $\begin{array}{c}\text { Sample } \\
\text { Type }\end{array}$ & $\begin{array}{c}\text { Reference } \\
\text { Date }\end{array}$ & $\begin{array}{l}\% \\
\text { T.o.c }\end{array}$ & Reference & Analyte & Value & Units & $\begin{array}{l}\text { SORWT } \\
\text { GROUP \# }\end{array}$ \\
\hline TY & 104 & TBP TC,F & 23200000 & Liquor & 08/12/85 & 0.17 & SD-RE-TI-182 Rev.0 6/30/87 & TOC & 2.05 & $\mathbf{g m} \mathbf{l}$ & 27 \\
\hline TY & 104 & TEP 1C,F & 241DO000 & Liquor & 08/06/85 & 0.20 & SD-RE-TI-182 Rev.0 6/30/87 & Toc & 2.41 & $\mathbf{g m} /$ & 27 \\
\hline TY & 104 & TBP 1C,F & RAT-TY104-1 & Sludge & $12 / 20 / 79$ & 0.40 & 65124-79-046 Rockwell 12/20/79 & TOC & 0.004 & gm/gm & 27 \\
\hline TY & 104 & TBP 1C,F & RAT-TY104-2 & Sludge & 09/18/80 & 2.80 & 65453-80-265 Rockwell 9/18/80 & TOC & 0.028 & $\mathrm{gm} / \mathrm{gm}$ & 27 \\
\hline TY & 104 & TBP 1C,F & 23250000 & Sludge/Composite & 08/06/85 & 0.21 & SD-RE-TI-182 Rev.0 6/30/87 & TOC & 2100 & ugm/gm & 27 \\
\hline TY & 104 & TBP 1C,F & 24160000 & Sludge/Composite & 08/06/85 & 0.28 & SD-RE-TI-182 Rev.0 6/30/87 & TOC & 2780 & ugm/gm & 27 \\
\hline TY & 104 & TBP 1C,F & 25150000 & Sludge/Composite & 08/14/85 & 0.20 & SD-RE-TI-182 Rev.0 6/30/87 & TOC & 1950 & ugm/gm & 27 \\
\hline TY & 104 & TBP 1C,F & 26150000 & Sludge/Composite & 08/16/85 & 0.09 & SD-RE-TI-182 Rev.0 6/30/87 & TOC & 907 & ugmigm & 27 \\
\hline TY & 105 & TBP & RAT-TY105-2 & Sludge & 09/18/80 & 1.00 & 65453-80-265 Rockwell 9/18/80 & TOC & 0.01 & $\mathrm{gm} / \mathrm{gm}$ & 25 \\
\hline TY & 105 & TBP & $61 \times c 0000$ & Sludge/Composite & 09/13/85 & 0.08 & SD-RE-TI-186 Rev.0 7/8/87 & TOC & 805 & ugm/gm & 25 \\
\hline TY & 106 & TBP & RAT-TY1,06-2 & Sludge & $09 / 18 / 80$ & 0.09 & 65453-80-265 Rockwell 9/18/80 & TOC & 0.00092 & $\mathrm{gm} / \mathrm{gm}$ & 25 \\
\hline TY & 106 & TBP & $111 C 0000$ & Sludge/Composite & 07/31/85 & 0.25 & SD-RE-TI-181 Rev.0 7/8/87 & TOC & 2480 & ugm/gm & 25 \\
\hline TY & 106 & TBP & $161 C 0000$ & Sludge/Composite & $09 / 26 / 85$ & 0.21 & SD-RE-TI-181 Rev.0 7/8/87 & TOC & 2090 & ugm/gm & 25 \\
\hline $\mathbf{U}$ & 103 & EB R & 8793 & Salts & $08 / 15 / 77$ & 3.38 & I.L. from JL Starr 12/14/77 Rockwel & roc & 44 & $\mathbf{g m} / \mathbf{l}$ & 7 \\
\hline u & 103 & EB R & 3064 & Solids & 12/04/78 & 0.69 & 60120-78-130 Rockwell 12/4/78 & TOC & 0.8 & moles/ & 7 \\
\hline $\mathbf{u}$ & 105 & EB CW & RAT-U105-3 & Salts & $12 / 04 / 78$ & 2.80 & 60120-78-125 Rockwell 12/4/78 & TOC & 2.8 & wt.\% & 10 \\
\hline u & 105 & EB CW & 968 & Solids & 10/06/77 & 3.38 & I.L. from JL Starr 1/10/78 Rockwell & TOC & 44 & $\mathbf{g m} / \mathbf{l}$ & 10 \\
\hline \multirow[t]{2}{*}{ u } & 106 & EB R & & & $01 / 01 / 80$ & 9.96 & RH_-SA-51 & TOC & 9.96 & wt.\% & 7 \\
\hline & & & & & & & Outline for Tank Characterization Report SST & & & & \\
\hline \multirow[t]{2}{*}{ u } & 110 & ungrouped. & segment 1 & Solids & 01/01/90 & 0.05 & $U-110$ & TOC & 0.05 & wt.\% & 30 \\
\hline & & & & & & & Outline for Tank Characterization Report SST & & & & \\
\hline \multirow[t]{2}{*}{ u } & 110 & ungrouped & segment 1 & Solids & 01/01/90 & 0.04 & $\mathrm{U}-110$ & roc & 0.04 & wt.\% & 30 \\
\hline & & & & & & & Outline for Tank Characterization Report SST & & & & \\
\hline \multirow[t]{2}{*}{ u } & 110 & ungrouped & segment 2 & Solids & 01/01/90 & 0.06 & $U-110$ & TOC & 0.06 & wt.\% & 30 \\
\hline & & & & & & & Outline for Tank Characterization Report SST & & & & \\
\hline \multirow[t]{2}{*}{ u } & 110 & ungrouped & segment 2 & Solids & $01 / 01 / 90$ & 0.07 & $\mathrm{U}-110$ & TOC & 0.07 & wt.\% & 30 \\
\hline & & & & & & & Outline for Tank Characterization Report SST & & & & \\
\hline \multirow[t]{2}{*}{ u } & 110 & ungrouped & segment 3 & Solids & 01/01/90 & 0.05 & $\mathrm{U}-110$ & TOC & 0.05 & wt.\% & 30 \\
\hline & & & & & & & Outline for Tank Characterization Report SST & & & & \\
\hline \multirow[t]{2}{*}{ u } & 110 & ungrouped & segment 3 & Solids & $01 / 01 / 90$ & 0.04 & $\mathrm{U}-110$ & TOC & 0.04 & wt.\% & 30 \\
\hline & & & & & & & Outline for Tank Characterization Report SST & & & & \\
\hline \multirow[t]{2}{*}{$\mathbf{u}$} & 110. & ungrouped & segment 4 & Solids & 01/01/90 & 0.11 & U-110 & TOC & 0.11 & wt.\% & 30 \\
\hline & & & & & & & Outline for Tank Characterization Report SST & & & & \\
\hline $\mathbf{u}$ & 110 & ungrouped & segment 4 & Solids & $01 / 01 / 90$ & 0.11 & $\mathrm{U}-110$ & TOC & 0.11 & wt.\% & 30 \\
\hline u & 111 & & & liquid & $01 / 01 / 80$ & 3.65 & RHO-SA-51 & TOC & 3.65 & wt.\% & 7 \\
\hline $\mathbf{u}$ & 111 & EB R & RAT-U111-2 & Slurry & $09 / 23 / 80$ & 0.62 & 65453-80-273 Rockwell 9/23/80 & TOC & 0.52 & wt.\% & 7 \\
\hline U & 111 & EB R & RAT-U111-3 & Slurry & $09 / 23 / 80$ & 0.54 & 65453-80-273 Rockwell 9/23/80 & TOC & 0.54 & wt.\% & 7 \\
\hline
\end{tabular}




\section{Appendix C}

Description of Sort On Radioactive Waste Type Groups 


\section{Appendix C}

\section{Description of Sort On Radioactive Waste Type Groups}

To further elaborate on the results of the Sort On Radioactive Waste Type (SORWT) model, brief descriptions of the most significant waste type groups predicted by the model have been included and are given below. Acronyms identifying the waste types are listed at the end of this appendix.

\begin{tabular}{|c|c|}
\hline $\mathbf{R}, \mathbf{E B}$ & Group Number 1) \\
\hline \multicolumn{2}{|c|}{$\begin{array}{l}\text { As previously mentioned, this waste type group is the most significant group predicted by } \\
\text { SORWT in terms of number of tanks and total waste volume. The } 21 \text { tanks within this } \\
\text { group contain } 9,798,000 \text { gallons of total waste-- } 8,361,000 \text { gallons of salt cake and } \\
1,328,000 \text { gallons of sludge. All } 21 \text { Group I tanks can be found in three different } 200 \text { West } \\
\text { Area Tank Farms--S, SX, and TX Farms. These tanks typically received a large amount of } \\
\text { high-level reduction oxidation (REDOX) waste (R) during the } 1950 \text { s. This waste is most } \\
\text { likely responsible for the sludge accumulation in these tanks. These tanks also received } \\
\text { large amounts of evaporator bottoms (EB), usually from the } 242-S \text { Evaporator in the early } \\
\text { 1970s. This super-saturated, high-nitrate waste cooled in the SSTs and formed an extremely } \\
\text { hard salt cake. Although the processing history of these tanks between the addition of the R } \\
\text { in the } 1950 \text { s and the EB in the } 1970 \text { s differs slightly, it is believed that these two waste } \\
\text { types predominantly dictate the physical and chemical characteristics of the waste. Some of } \\
\text { the tanks in this group have no reported sludge accumulation. This is probably because } \\
\text { poor measurements were taken before salt cake formation. Once the salt cake crystallized } \\
\text { in a tank, it became impossible to measure the volume of sludge. Because of the extreme } \\
\text { hardness of the salt cake, there are technical obstacles that prevent core sampling any of } \\
\text { these tanks at this time. }\end{array}$} \\
\hline & \\
\hline \multicolumn{2}{|c|}{$\begin{array}{l}\text { This 9-tank group contains approximately } 3,985,000 \text { gallons of waste. The vast majority of } \\
\text { this waste--3,945,000 gallons--is salt cake. All but two of these tanks are located in the TX } \\
\text { Tank Farm. One tank is located in B Tank Farm. These tanks are characterized as having } \\
\text { received large quantities of EB, mainly from the } 242-\mathrm{T} \text { Evaporator. They also received } \\
\text { modest quantities of } 1 \mathrm{C} \text { waste. Tank B-105 received } 1 \mathrm{C} \text { before the EB, which might } \\
\text { explain the limited sludge accumulation in this tank not exhibited by the others. Once } \\
\text { again, the hard salt cake formation raises significant technical issues that must be solved } \\
\text { before sampling these tanks. }\end{array}$} \\
\hline
\end{tabular}

C.1 


\begin{tabular}{|c|c|}
\hline TBP-F, EB-ITS & (Group Number 3) \\
\hline \multicolumn{2}{|c|}{$\begin{array}{l}\text { This group contains } 10 \text { tanks and is the second most significant in terms of number of tanks } \\
\text { and total waste volume. The tanks in this group hold 3,980,000 gallons of waste. The } \\
\text { majority of this waste--3,344,000 gallons--is salt cake. These tanks also contain substantial } \\
\text { amount of sludge. All } 10 \text { of these tanks can be found in the BY Farm located in the } 200 \\
\text { East Area. These tanks originally held metal waste (MW) from the bismuth phosphate } \\
\text { process but were completely sluiced out in the early } 1950 \text { s. No significant amounts of MW } \\
\text { remained in the tanks and it is not considered by the SORWT model. After sluicing, these } \\
\text { tanks received tributyl phosphate (TBP) ferrocyanide-scavenged waste from U Plant. This } \\
\text { scavenged waste is probably responsible for the sludge buildup in the tank. During the late } \\
\text { 1960s and early } 1970 \text { s, these tanks were connected to the In-Tank Solidification (ITS-2) } \\
\text { loops. This process, by which one tank in the loop was used as an in-tank evaporator and } \\
\text { the rest of the tanks as liquid holders, concentrated the waste and reduced the liquid } \\
\text { volume. This resulted in salt cake formation. In light of the presence of high } \\
\text { concentrations of ferrocyanide in these tanks and the hardness of the salt cake, there are } \\
\text { significant safety and technical difficulties associated with sampling this waste type group. }\end{array}$} \\
\hline & \\
\hline \multicolumn{2}{|c|}{$\begin{array}{l}\text { This 7-tank group, located almost entirely in BX Tank Farm, contains } 489,000 \text { gallons of } \\
\text { waste. Nearly all of the contents of this group is sludge. Salt cake has only been observed } \\
\text { in one tank (BX-105) and the } 3,000 \text { gallons of salt cake is due to a small transfer of EB into } \\
\text { that particular tank. These tanks were originally filled with MW in the } 1940 \mathrm{~s} \text {. In the early } \\
\text { 1950s they were sluiced of their contents to provide room for TBP waste. Addition of this } \\
\text { waste type began in the mid-1950s. The addition of cladding waste began in the mid-1960s } \\
\text { The various other transfers that occurred in these tanks should not affect the characteristic } \\
\text { of the waste significantly, relative to the primary and secondary wastes. Tanks BX-105 and } \\
\text { Tank BX-106 were core sampled previously and provide insight into the chemical composi- } \\
\text { tion of these tanks. Additional sampling of these tanks poses no technical or safety issues. } \\
\text { Tank BX-104 is on the Push-Mode List and would be a good choice for sampling. }\end{array}$} \\
\hline
\end{tabular}




\begin{tabular}{|c|c|}
\hline 224 & (Group Number 5) \\
\hline \multicolumn{2}{|c|}{$\begin{array}{l}\text { This } 8 \text {-tank group represents } 280,000 \text { gallons of waste. The majority of the waste is sludge. } \\
\text { No salt cake formation has been observed in these tanks. All } 8 \text { tanks are } 55,000 \text {-gallons, } \\
200 \text { Series tanks located in B Tank Farm and T Tank Farm. These tanks received exclus- } \\
\text { ively } 224 \text { waste. In light of the singularity of the waste type introduced into these tanks and } \\
\text { the similarity of process history (i.e., the near absence of any inter-tank transfers), the } \\
\text { composition of this group should be very uniform between tanks. There are no safety or } \\
\text { technical issues prohibiting the sampling of these tanks. Tanks B-201 and B- } 202 \text { have been } \\
\text { selected in the Waste Characterization Plan, Rev. } 2 \text { (WHC), as the next single-shell tanks } \\
\text { (SST) to be sampled. These sampling events should occur in the summer of } 1991 \text {. The two } \\
\text { sets of core sample analyses will aid in measuring the uniformity of the waste in this tank } \\
\text { group. }\end{array}$} \\
\hline $\mathbf{R}$ & \\
\hline \multicolumn{2}{|c|}{$\begin{array}{l}\text { Group V is a 7-tank group exclusively containing high-level R. These tanks hold } 892,000 \\
\text { gallons of waste. The majority of waste-- } 888,000 \text { gallons--is sludge. No salt cake form- } \\
\text { ation has been observed in these tanks. It is of interest to note that R forms sludge without } \\
\text { any further waste volume-reduction processes. Five of these tanks can be found in the SX } \\
\text { Tank Farm and all are located in the } 200 \text { West Area. There are no safety or technical } \\
\text { sampling issues associated with the majority of this group. The exception is Tank SX-109, } \\
\text { which is on the Wyden Bill List as a gas-generating tank. Tank S-104 is on the Push-Mode } \\
\text { List core sampling list. Sampling and analysis of S-104 would contribute greatly to the } \\
\text { existing body of characterization knowledge. The analysis of this tank would not only } \\
\text { significantly aid in characterizing this particular 7-tank group but would also help character- } \\
\text { ize several other groups containing large amounts of R-type waste. }\end{array}$} \\
\hline & \\
\hline \multicolumn{2}{|c|}{$\begin{array}{l}\text { Group VII consists of five } 200 \text { West Area tanks, mostly from U Farm. These tanks contain } \\
2,037,000 \text { gallons of waste. The vast majority of waste is salt cake. These tanks were } \\
\text { filled with MW in the } 1940 \text { s, but were completely sluiced out in the early } 1950 \text { s. Large } \\
\text { quantities of high-level R were introduced into these tanks and allowed to remain there for } \\
\text { many years. In the early } 1970 \text { s, large volumes of R supernate were transferred from the } \\
\text { tank and replaced with EB from the } 242-S \text { Evaporator. This caused a salt cake to form over } \\
\text { the majority of these tanks. The small amount of sludge that accumulated in these tanks is } \\
\text { probably due to the R present before the EB. In light of the hardness of the salt cake, these } \\
\text { tanks offer technical difficulties that must be solved before sampling. These tanks should be } \\
\text { very similar to Group I tanks and differ from Group I mainly in the ratios of R to EB. } \\
\text { These tanks might be so similar that they can be included with that group; however, these } \\
\text { similarities can only be verified by core samples. }\end{array}$} \\
\hline
\end{tabular}




\begin{tabular}{|c|c|}
\hline TBP-F, 1C & (Group Number 8) \\
\hline \multicolumn{2}{|c|}{$\begin{array}{l}\text { This 5-tank group contains } 478,000 \text { gallons of waste and approximately } 465,000 \text { gallons is } \\
\text { sludge. No salt cake has been observed in these tanks. The } 4 \mathrm{C} \text { farm tanks were used as the } \\
\text { primary settling tanks during the In-Farm Scavenging campaign during the } 1950 \mathrm{~s} \text {. These } \\
\text { four tanks were originally filled with } 1 \mathrm{C} \text { waste in the } 1940 \mathrm{~s} \text {. The supernate was transferred } \\
\text { out of the tanks to make room for the TBP-scavenged waste that was allowed to settle. } \\
\text { These two wastes formed the vast majority of the solids located in these two tanks. The } \\
\text { other tank in this group (T-107) has a processing history similar to the rest of this group. } \\
\text { The difference is it received its ferrocyanide scavenged TBP waste from the U Plant } \\
\text { scavenged test. These two TBP-F wastes may be slightly different. All of these tanks are } \\
\text { on the Wyden Bill List because of their ferrocyanide content. Although none of these tanks } \\
\text { are on the Push-Mode List, recent surveillance photographs of C-112 indicate that the crust } \\
\text { is relatively soft and should pose no technical difficulties in sampling. However, significant } \\
\text { safety issues need to be resolved before a sampling event. Because C-112 was the most } \\
\text { frequently used In-Farm Scavenging tank, it would be of immense interest to the safety } \\
\text { program and provide valuable insight into the ferrocyanide safety issue. }\end{array}$} \\
\hline & \\
\hline \multicolumn{2}{|c|}{$\begin{array}{l}\text { This 4-tank group contains a total of } 2,113,000 \text { gallons of waste. Salt cake comprises } \\
1,717,000 \text { gallons of this waste while } 387,000 \text { gallons are sludge. These tanks initially } \\
\text { received either plutonium-uranium extraction (PUREX) high-activity, neutralized acid waste } \\
\text { (P) or B Plant high-level waste (B). However, all of these tanks were sluiced of their con- } \\
\text { tents in } 1976 \text {. The waste types added to these tanks after sluicing were DSSF and Noncom- } \\
\text { plexed waste. These waste types -generic terms describing the potential for further } \\
\text { processing of the waste instead of the original source of waste. Because these generic terms } \\
\text { are so general, little can be determined concerning the homogeneity of the waste in this } \\
\text { group. In fact, one tank in this group contains only sludge while the rest contain mostly salt } \\
\text { cake. Although the total volume of this group is highly significant, the uncertainty of the } \\
\text { waste types in these tanks makes this group less important. }\end{array}$} \\
\hline
\end{tabular}




\begin{tabular}{|c|c|}
\hline $\mathbf{E B}, \mathbf{C W}$ & (Group Number 10) \\
\hline \multicolumn{2}{|c|}{$\begin{array}{l}\text { These four tanks (all in U Farm) contain } 1,755,000 \text { gallons of waste. Salt cake comprises } \\
1,520,000 \text { gallons of this waste while sludge comprises only } 124,000 \text { gallons. These tanks } \\
\text { were filled with MW in the late } 1940 \text { s or early } 1950 \text { s. In the mid- to late } 1950 \text { s, the MW } \\
\text { was sluiced from the tank to provide room for CW. The supernatant portions of the CW } \\
\text { were flushed out of the tanks in the early } 1970 \text { s by various liquid transfers. In the mid- to } \\
\text { late } 1970 \text { s, large amounts of EB from the REDOX evaporator and the } 242-S \text { Evaporator } \\
\text { were added to these tanks. (The EB are responsible for the salt cake formation.) All of the } \\
\text { tanks are on the Wyden Bill List for either gas generation or acetate contents; therefore, } \\
\text { there are safety and technical issues pertaining to sampling this tank. }\end{array}$} \\
\hline 1C, TBP & up Number 11) \\
\hline \multicolumn{2}{|c|}{$\begin{array}{l}\text { This 5-tank group contains } 715,000 \text { gallons of waste. The vast majority of waste is sludge. } \\
\text { Even though this group transcends four different Tank Farms in both the } 200 \text { East Area and } \\
\text { the } 200 \text { West Area, these tanks have very similar processing histories. They were filled } \\
\text { with } 1 \mathrm{C} \text { waste in the } 1940 \mathrm{~s} \text {. A portion of this volume was drained in the early } 1950 \mathrm{~s} \text { and } \\
\text { that tanks began receiving TBP waste. The solids volume that was measured at this time } \\
\text { did not accumulate further during the rest of these tanks' histories. The additional transfers } \\
\text { were mostly liquid in nature and had little effect on the sludge volume. No salt cake has } \\
\text { been observed in these tanks, even though a small amount of EB was introduced into T-108 } \\
\text { (apparently not enough to catalyze crystallization). Although none of these tanks are on the } \\
\text { Push-Mode List, recent surveillance photographs from Tank BX-107 indicate that the crust } \\
\text { is soft and should not pose any problems for sampling. }\end{array}$} \\
\hline & (Group Number 12) \\
\hline \multicolumn{2}{|c|}{$\begin{array}{l}\text { This 4-tank group of B and BX Farm tanks contains } 553,000 \text { gallons of waste. Nearly all of } \\
\text { the waste is sludge. These tanks all received } 1 \mathrm{C} \text { waste in the late } 1940 \text { s and early } 1950 \mathrm{~s} \text {. } \\
\text { In the mid-1950s the supernatant portion of the } 1 \mathrm{C} \text { waste was transferred from the tanks and } \\
\text { they began receiving EB waste. The EB must not have been very concentrated because the } \\
\text { characteristic salt cake did not form. All of these tanks also received appreciable amounts } \\
\text { of CW in the } 1960 \mathrm{~s} \text {. }\end{array}$} \\
\hline
\end{tabular}




\begin{tabular}{|c|c|}
\hline & \\
\hline \multicolumn{2}{|c|}{$\begin{array}{l}\text { This 4-tank group of } 55,000 \text {-gallons, } 200 \text { Series tanks is located in the C Tank Farm. } \\
\text { These tanks received MW in the } 1940 \text { s but were sluiced in the early } 1950 \text { s. After sluicing, } \\
\text { these tanks received only waste from the Hot Semiworks. The majority of this waste was } \\
\text { removed from these tanks in the late } 1960 \text { s and early } 1970 \text { s. The total waste remaining in } \\
\text { these tanks is only } 11,000 \text { gallons. This minor volume designates this tank group as being } \\
\text { insignificant relative to other groups or even single tanks. }\end{array}$} \\
\hline & \\
\hline \multicolumn{2}{|c|}{$\begin{array}{l}\text { l waste. The majority of waste-- } 892,000 \\
\text { ed in a 3-tank cascade. The processing } \\
\text { ceived } 2 \mathrm{C} \text { waste in the } 1940 \text { s and early } \\
\text { anks began receiving } 224 \text { waste and the } \\
\text { two tanks in the cascade (T-110 and } \\
12 \text { received dilute decontamination waste } \\
60 \text { s and early } 1970 \text { s. These transfers } \\
\text { stics of the waste relative to the first two } \\
\text { st, should not pose any safety or technical } \\
\text { ing. Tank T-110 is on the Wyden Bill }\end{array}$} \\
\hline & \\
\hline \multicolumn{2}{|r|}{$\begin{array}{l}00 \text { East Area, contains } 516,000 \\
\text { ns--is sludge. These three tanks also } \\
\text { riginally filled with } 2 C \text { waste in the } \\
\text { le continuous overflow in B-112 was } \\
\text { Plant in } 1952 \text { and fission products } \\
\text { (BL) and ion exchange waste (IX) in } \\
\text { quid in nature and are not consid- } \\
\text { l characteristics of the solids } \\
\text { tes. Tank B-112 received EB and } \\
\text { cause the formation of salt cake } \\
\text { a Tank B-110 were obtained in } 1989 \text { - } \\
\text { acterization Program. These core } \\
\text { ide excellent data for physical and }\end{array}$} \\
\hline
\end{tabular}




\begin{tabular}{|c|c|}
\hline $\mathbf{R}, \mathbf{R I X}$ & (Group Number 16) \\
\hline \multicolumn{2}{|c|}{$\begin{array}{l}\text { Group XVI consists of three SX farm tanks, which hold } 368,000 \text { gallons of waste. All of } \\
\text { this waste is sludge: These tanks received REDOX high-level waste after they were } \\
\text { released to operations in the mid- to late } 1950 \text { s. These tanks received only R until the early } \\
1970 \text { s when RIX was introduced into these tanks. In the mid- to late } 1970 \text { s, these tanks } \\
\text { received minor quantities of various waste types, mostly liquid in nature. Tank SX-114 } \\
\text { received a small amount of EB waste but not in sufficient concentrations to catalyze crystal } \\
\text { formation. }\end{array}$} \\
\hline $1 \mathrm{C}$, & 7) \\
\hline \multicolumn{2}{|c|}{$\begin{array}{l}\text { These two T Farm tanks contain } 119,000 \text { gallons of waste. The majority of waste-- } 2,000 \\
\text { gallons--is sludge. No salt cake has been observed in these tanks. These tanks initially } \\
\text { received } 2 \mathrm{C} \text { waste in } 1947 \text {. The cascade was then filled with } 1 \mathrm{C} \text { waste from } 1948 \text { until } \\
\text { 1955. These tanks then began receiving CW in large quantities. A large amount of solids } \\
\text { accumulation has resulted from these three waste types. In the 1970s, a number of different } \\
\text { liquid wastes was transferred through these two tanks but these wasted did not affect the } \\
\text { solids content to the degree of the previous three wastes. }\end{array}$} \\
\hline $\mathbf{C W}, \mathbf{E B}$ & (Group Number 18) \\
\hline \multicolumn{2}{|c|}{$\begin{array}{l}\text { This 3-tank group contains } 204,000 \text { gallons of waste. The cast majority of this waste is } \\
\text { sludge, but } 10,000 \text { gallons of salt cake has formed in one of the tanks. These tanks also } \\
\text { were connected in a 3-tank cascade. The cascade was originally filled with MW in the } \\
1940 \text { s and, as was typical with MW, sluiced out in the early } 1950 \text { s. The cascade then began } \\
\text { receiving evaporated cladding waste (CW). Apparently the CW was not concentrated to the } \\
\text { point of salt cake formation because of the limited amount of this waste form observed in } \\
\text { the tank. The cascade also received unconcentrated CW in the } 1960 \text { s. These tanks received } \\
\text { BL and IX in the } 1970 \text { s, but these predominately liquid wastes are not considered to have } \\
\text { significantly contributed to the solids formation in the tank. }\end{array}$} \\
\hline
\end{tabular}




\begin{tabular}{|c|c|}
\hline CW, MIX & (Group Number 19) \\
\hline \multicolumn{2}{|c|}{$\begin{array}{l}\text { This 3-tank cascade currently hold } 192,000 \text { gallons of waste. The majority of waste-- } \\
145,000 \text { gallons--is sludge. No salt cake has been observed in these tanks. The cascade was } \\
\text { initially filled with MW in the } 1940 \text { s and emptied in } 1951 \text {. Tank T-101 received a small } \\
\text { amount of TBP scavenged waste from a plant pilot test of the process. This waste was then } \\
\text { flushed from the tank. The cascade was again filled with MW in } 1955 \text { but emptied the fol- } \\
\text { lowing year. Tank. T-101 is listed as a ferrocyanide tank, but this waste was removed and the } \\
\text { tank was effectively sluiced twice afterwards. It is unlikely that any appreciable amount of } \\
\text { ferrocyanide remains in this tank. The empty cascade was then filled with CW beginning in } \\
1957 \text {. This single waste type remained until the early } 1970 \text { s, when a mixture of liquid waste } \\
\text { was flushed through this cascade. The liquid wastes are considered to have had only a } \\
\text { limited impact on the characteristic of the solid waste remaining in the tank. Tank T-101 is } \\
\text { on the Push-Mode List and would therefore present no technical difficulties in sampling. Its } \\
\text { presence on the Wyden Bill List is due to the hypothesized ferrocyanide content. Successful } \\
\text { sampling and analysis of this tank might ensure the absence of this compound and remove } \\
\text { this tank from the Wyden Bill List. This makes the tank a quality selection for sampling. }\end{array}$} \\
\hline $\mathbf{C W}$ & (Group Number 20) \\
\hline \multicolumn{2}{|c|}{$\begin{array}{l}\text { These three } 200-\text { Series tanks from U Farm contain only } 13,000 \text { gallons of waste. The history } \\
\text { of these tanks indicates that the predominant waste type in these tanks is CW. The insign- } \\
\text { ificant amount of waste contained in these tanks makes this group virtually irrelevant. }\end{array}$} \\
\hline & \\
\hline \multicolumn{2}{|c|}{$\begin{array}{l}\text { This pair of BY Farm tanks contains a combined total of } 907,000 \text { gallons of waste. The } \\
\text { majority of this waste-- } 771,000 \text { gallons-- is salt cake while } 87,000 \text { gallons is sludge. Both } \\
\text { tanks received MW before } 1955 \text { but were sluiced of their contents. Beginning in } 1955 \text {, both } \\
\text { tanks received TBP waste. Both tanks received quantities of CW in the early } 1960 \text { s and were } \\
\text { connected to an ITS loop in the late } 1960 \text { s. Tank BY-102 belonged to ITS No. } 1 \text { and BY-109 } \\
\text { belonged to ITS No. } 2 \text {. Despite being connected to different ITS loops (and operated by } \\
\text { different principles), the solids remaining in the two tanks can be expected to be relatively } \\
\text { similar. These tanks both received TBP and CW before ITS. The hardness of the salt cake } \\
\text { will prohibit sampling until a hard cake sampler is developed. }\end{array}$} \\
\hline
\end{tabular}




\begin{tabular}{|c|c|}
\hline EB, TBP & (Group Number 22) \\
\hline \multicolumn{2}{|c|}{$\begin{array}{l}\text { This pair of TX Farm tanks contains } 481,000 \text { gallons of waste and all of it is salt cake. The } \\
\text { processing history of these two tanks is slightly different; however, the major waste types } \\
\text { are the same. Tank TX-108 received MW in the late } 1940 \text { s, which was sluiced out in the } \\
\text { early } 1950 \text { s. A minor quantity of R waste was introduced into this tank in the mid-1950s. } \\
\text { On top of this R heel, a substantial amount of TBP waste was added. Tank TX-118 } \\
\text { received 1C waste in the early } 1950 \text { s. Most of this waste type was transferred out of the } \\
\text { tank. The TBP waste was added on top of this heel. In the late } 1960 \text { s and early } 1970 \mathrm{~s} \text {, } \\
\text { significant quantities of EB from the } 242-\mathrm{T} \text { Evaporator were added to both of these tanks, } \\
\text { which caused salt cake formation. Tank TX-118 is on the Wyden Bill List because of } \\
\text { unconfirmed transfers of ferrocyanide-scavenged waste. }\end{array}$} \\
\hline SRS, TBP & \\
\hline \multicolumn{2}{|c|}{$\begin{array}{l}\text { Both of the tanks in this group are located in C Farm and contain } 429,000 \text { gallons of waste. } \\
\text { The bulk of this volume--372,000 gallons--is sludge. This group received MW in the } 1940 \text { s } \\
\text { but this waste type was removed from these tanks in the early } 1950 \text { s. The group was then } \\
\text { filled with TBP waste. During the } 1960 \text { s, these tanks received various quantities of P and } \\
\text { CW. In the early } 1970 \text { s, these tanks received large quantities of a highly mixed liquid } \\
\text { waste, which was later transferred out. This liquid probably did not greatly affect the } \\
\text { solids. In } 1976 \text { and } 1977 \text { these tanks received a large transfer of strontium sludge (SRS), } \\
\text { which greatly added to the solids volume in the tank. This waste type was considered the } \\
\text { most significant contributor to the solids characteristics because of its relatively large } \\
\text { volume and high radioactivity content. }\end{array}$} \\
\hline
\end{tabular}




\begin{tabular}{|c|c|}
\hline 1C, EB-ITS & (Group Number 24) \\
\hline \multicolumn{2}{|c|}{$\begin{array}{l}\text { The two BX Farm tanks contain } 429,000 \text { gallons of waste- } 152,000 \text { gallons of salt cake and } \\
257,000 \text { gallons of sludge. Both of these tanks received } 1 \mathrm{C} \text { waste in the late } 1940 \text { s and } \\
\text { early } 1950 \text { s. Tank BX-110 received some EB in the mid- to late } 1950 \text { s. Both tanks re- } \\
\text { ceived CW and IX wastes in the before } 1960 \text { s before receiving EB from one of the ITS } \\
\text { loops. The physical forms of the waste, as reported by Hanlon }(1990) \text {, are very different } \\
\text { for these two tanks. The majority of BX-110 is sludge and only } 9,000 \text { gallons ( } \approx 31 / 4 \\
\text { inches) is salt cake. Tank BX-111 exhibits a greater amount of salt cake (143,000 gallons) } \\
\text { than sludge ( } 68,000 \text { gallons). These differences in the reported physical form might result } \\
\text { from imprecise sludge measurements during the early history of these tanks or it might be } \\
\text { the consequence of real differences between the tanks. This question cannot be answered } \\
\text { until one or both of the tanks has been core sampled. }\end{array}$} \\
\hline $\mathbf{T B P}$ & (Group Number 25) \\
\hline \multicolumn{2}{|c|}{$\begin{array}{l}\text { This pair of TY Farm tanks contains } 248,000 \text { gallons of waste. All of this waste is sludge. } \\
\text { These tanks had a very simple processing history. (They received only one waste type-- } \\
\text { TBP.) These tanks have been previously core sampled, and selected portions of the analyt- } \\
\text { ical results can be found in Appendix E. }\end{array}$} \\
\hline TBP, EB & (Group Number 26) \\
\hline \multicolumn{2}{|c|}{$\begin{array}{l}\text { This pair of tanks T } 109 \text { and TX } 103 \text { comprise sludge waste with a total volume of } 215,000 \\
\text { gallons of waste. These tank comprise } 1 \% \text { of the sludge of the total volume of all tanks. } \\
\text { Both tanks received TBP waste. }\end{array}$} \\
\hline TBP, 1C-F & (Group Number 27) \\
\hline \multicolumn{2}{|c|}{$\begin{array}{l}\text { This pair of ferrocyanide tanks is located in TY Farm and contains } 208,000 \text { gallons of } \\
\text { waste. The majority of waste-- } 205,000 \text { gallons--is sludge. No salt cake has been observed } \\
\text { in these tanks. These tanks received TBP waste in the early } 1950 \mathrm{~s} \text {. During the mid-1950s, } \\
\text { the supernate was transferred out and ferrocyanide-scavenged } 1 \mathrm{C} \text { waste placed on top of the } \\
\text { TBP heel. These two waste types caused significant solids accumulation. During the } 1960 \mathrm{~s} \\
\text { and } 1970 \mathrm{~s} \text {, a variety of waste was transferred into and out of these tanks. The solids } \\
\text { accumulation did not substantially change during these transfers; therefore, these later } \\
\text { transfers are not considered to have affected the physical and chemical characteristics of the } \\
\text { solids already present in the tank. }\end{array}$} \\
\hline
\end{tabular}




\begin{tabular}{|c|c|}
\hline CCPLX, DSSF & (Group Number 28) \\
\hline \multicolumn{2}{|c|}{$\begin{array}{l}\text { This group of two AX Farm tanks contains } 151,000 \text { gallons of waste. The waste consists of } \\
40,000 \text { gallons of salt cake, } 9,000 \text { gallons of sludge, and the remainder supernate. Both of } \\
\text { these tanks were sluiced of their contents in } 1977 \text {, leaving a } 6,000 \text {-gal heel of } P \text { waste. The } \\
\text { tanks then received wastes identified by unspecific waste names like concentrated complex- } \\
\text { ed waste (CCPLX), double-shell slurry feed (DSSF), and evaporator feed (EVAP). Using } \\
\text { such broad waste identifiers--based on suitability for further treatment, not waste source-- } \\
\text { precludes grouping by radioactive waste type. }\end{array}$} \\
\hline $\mathbf{R}, \mathbf{D I A}$ & (Group Number 29) \\
\hline \multicolumn{2}{|c|}{$\begin{array}{l}\text { This pair of assumed leaker tanks contains } 148,000 \text { gallons of waste. All of this waste is } \\
\text { sludge. Tank U-104 initially received MW in the } 1940 \text { s but this waste type was sluiced } \\
\text { from the tank in the early } 1950 \text { s. Tank SX-113 was not released to operation until the mid- } \\
1950 \text { s. Both tanks exclusively received R after } 1958 \text {. Diatamaceous earth was added to } \\
\text { both tanks after they were declared leakers in an attempt to prevent the escape of liquid } \\
\text { waste. }\end{array}$} \\
\hline Solitary Tanks (Ungrouped) & (Group Number 30) \\
\hline \multicolumn{2}{|c|}{$\begin{array}{l}\text { Of the } 149 \text { SSTs, only } 18 \text { did not fall into groups based on radioactive waste types. These } \\
18 \text { tanks transcend almost every waste type and every Tank Farm in the } 200 \text { East and } 200 \\
\text { West Areas. They contain both salt cake and sludge. These ungrouped tanks represent } \\
3,794,000 \text { gallons of waste-- } 1,241,000 \text { gallons of salt cake and } 2,509,000 \text { gallons of sludge. } \\
\text { Several of these tanks have significant quantities of waste in them and others have relatively } \\
\text { little waste. Many of these tanks are related to some of the groups previously described. }\end{array}$} \\
\hline
\end{tabular}




\section{ACRONYMS}

1C first-cycle decontamination waste

224 lanthanum fluoride decontamination waste

2C second-cycle decontamination waste

5-6 high-level B Plant waste

CCPLX complex concentrate

CW cladding waste

DIA diatomateous earth

DSSF double-shell slurry feed

EB evaporator bottoms

F ferrocyanide-scavenged waste

HS hot semiworks waste

ITS in-tank solidification

MIX mixture of several miscellaneous wastes

NCPLX noncomplexed waste

$\mathrm{R}$ high-level REDOX (reduction oxidation) waste

RIX REDOX ion exchange waste

SRS strontium sludge

TBP tributyl phosphate 


\section{Appendix D}

Laboratory Report Source Information 


\section{Appendix D}

\section{Laboratory Report Source Information}

Letter, M. T. Jansky to J. W. Baily, "Sample From 108-TX," 65453-81-036, dated February 5, 1981.

Letter, A. J. DiLiberto to K. W. Owens, "Response to May 18th Request from Washington Department of Ecology (WDOE)," 13311C-88-0439, dated June 18, 1988.

Letter, M. T. Jansky to M. C. Teats, "Composition of 101-A Waste," 65453-80-302, dated October 13, 1980.

Letter, R. L. Weiss to J. A. Eaker, "Analysis of Tank 241-AX-102," 12712-PCL88-018, dated November 14, 1988.

Letter, R. L. Weiss to K. G. Carothers, "Analysis of Tank 241-SX-104 Samples, Revision 1," 12221-PCL88-190, dated August 15, 1988.

Letter, M. T. Jansky to D. E. Bowers, "Freezing of Tank 111-U Waste," 65453-80-273, dated September 23, 1980.

Letter, M. T. Jansky to M. C. Teats, "Solids in 101-A Waste," 65453-80-267, dated September 22, 1980.

Letter, R. L. Weiss to V. C. Boyles, "Analysis of Liquid Sample from Tank 241-A-102," 12712-PCL89-112, dated May 9, 1989.

Letter, M. T. Jansky to M. C. Teats, "Composition of 103-A Waste," 65453-80-277, dated September 24, 1980.

Letter, M. T. Jansky to D. E. Bowers and D. A. Reynolds, "Composition of Waste from Tank 101-AX," 65453-80-293, dated October 7, 1980.

Letter, M. E. Mitchell to D. J. Flesher, "Physical and Chemical Characterization of Tanks 104-TY and 106-TY," 65124-79-046, dated December 20, 1979.

Letter, M. J. Klem to R. E. Raymond "Total Organic Carbon Concentration of Single Shell Tank Waste", 82316-90-032, dated April 27, 1990. 
Van Vleet, R. J., Radionuclide and Chemical Inventories for the Double Shell Tanks, WHC-SD-WM-TI-543, August 1993.

Weiss, R. L., and K. E. Schull. 1986. Data Transmittal for 241-A-106 Waste Tank Characterization. SD-RE-TI-200, Rev 0. Rockwell Hanford Operations, Richland, Washington.

Weiss, R. L., and K. E. Schull. 1986. Data Transmittal for 241-A-104 Waste Tank Characterization. SD-RE-TI-207, Rev 0. Rockwell Hanford Operations, Richland, Washington.

Weiss, R. L., and K. E. Schull. 1986. Data Transmittal for 241-BX-104 Waste Tank Characterization. SD-RE-TI-206, Rev 0. Rockwell Hanford Operations, Richland, Washington.

Weiss, R. L., and K. E. Schull. 1986. Data Transmittal for 241-A-102 Waste Tank Characterization, SD-RE-TI-201, Rev 0. Rockwell Hanford Operations, Richland, Washington.

Weiss, R. L., and K. E. Schull. 1986. Data Transmittal for 241-BX-105 Waste Tank Characterization. SD-RE-TI-202, Rev 0. Rockwell Hanford Operations, Richland, Washington.

Weiss, R. L., and K. E. Schull. 1986. Data Transmittal for 241-A-103 Waste Tank Characterization. SD-RE-TI-198, Rev 0. Rockwell Hanford Operations, Richland, Washington.

Weiss, R. L., and K. E. Schull. 1986. Data Transmittal for 241-C-103 Waste Tank Characterization. SD-RE-TI-203, Rev 0. Rockwell Hanford Operations, Richland, Washington.

Weiss, R. L., and B. M. Mauss. 1985. Data Transmittal for 241-TY-102 Waste Tank Characterization. SD-RE-TI-183, Rev 0. Rockwell Hanford Operations, Richland, Washington.

Weiss, R. L., and B. M. Mauss. 1985. Data Transmittal for 241-TY-101 Waste Tank Characterization. SD-RE-TI-185, Rev 0. Rockwell Hanford Operations, Richland, Washington.

Weiss, R. L., and K. E. Schull. 1986. Data Transmittal for 241-C-106 Waste Tank Characterization. SD-RE-TI-204, Rev 0. Rockwell Hanford Operations, Richland, Washington.

Weiss, R. L., and B. M. Mauss. 1985. Data Transmittal for 241-TY-103 Waste Tank Characterization. SD-RE-TI-184, Rev 0. Rockwell Hanford Operations, Richland, Washington.

Weiss, R. L., and B. M. Mauss. 1985. Data Transmittal for 241-TY-104 Waste Tank Characterization. SD-RE-TI-182, Rev 0. Rockwell Hanford Operations, Richland, Washington. 
Weiss, R. L., and K. E. Schull. 1986. Data Transmittal for 241-C-104 Waste Tank Characterization. SD-RE-TI-199, Rev 0. Rockwell Hanford Operations, Richland, Washington.

Weiss, R. L., and B. M. Mauss. 1985. Data Transmittal for 241-TY-106 Waste Tank

Characterization. SD-RE-TI-181, Rev 0. Rockwell Hanford Operations, Richland, Washington.

Weiss, R. L., and B. M. Mauss. 1985. Data Transmittal for 241-TY-105 Waste Tank

Characterization. SD-RE-TI-186, Rev 0. Rockwell Hanford Operations, Richland, Washington.

Weiss, R. L., and K. E. Schull. 1986. Data Transmittal for 241-C-105 Waste Tank

Characterization. SD-RE-TI-204, Rev 0. Rockwell Hanford Operations, Richland, Washington. 


\section{Distribution}

No. of

Copies

$\underline{\text { Offsite }}$

12 DOE/Office of Scientific and Technical Information

S. F. Agnew

Los Alamos National Laboratory

P. O. Box 1663

Los Alamos, NM 87545

Onsite

6 DOE Richland Operations Office

R. F. Christensen

S7-54

G. W. Rosenwald

S. O. Branch

Public Reading Room

RL Docket File (2)

MACTEC

S. J. Murff, R3-82

FAI

M. G. Plys, H4-62
No. of

Copies

7 Westinghouse Hanford Company

H. Babad

S7-30

M. A. Islam

H5-57

C. Defigh-Price

X3-71

J. P. Sederburg

R2-11

D. A. Turner (2)

R. C. Roal

S7-15

21 Pacific Northwest Laboratory

W. J. Apley

P8-30

R. M. Bean

K9-76

J. A. Campbell

J. O. Heaberlin

P. G. Heasler

P8-08

K8-31

P. J. Mellinger

K5-12

D. R. Payson

K9-76

J. J. Toth

K7-90

K7-94

P. D. Whitney

K5-12

C. E. Willingham Jr.

K8-41

T. W. Wood

Organic Waste Tank Safety

Project File (4)

Publishing Coordination

Technical Report Files (5) 